\author{
UNIVERSIDADE DE SÃO PAULO \\ FACULDADE DE ZOOTECNIA E ENGENHARIA DE ALIMENTOS
}

RUBENS CORRÊA JUNIOR

O fluxo de caixa como direcionador do processo de reestruturação de uma empresa avícola de postura comercial 


\section{RUBENS CORRÊA JUNIOR}

\section{O fluxo de caixa como direcionador do processo de reestruturação de uma}

empresa avícola de postura comercial

Versão corrigida

Dissertação apresentada à Faculdade de Zootecnia e Engenharia de Alimentos da Universidade de São Paulo, como parte dos requisitos para a obtenção do título de Mestre em Administração do programa de Mestrado Profissional em Gestão e Inovação na Indústria Animal.

Área de Concentração: Gestão e Inovação na Indústria Animal

Orientador: Prof. Dr. Augusto Hauber Gameiro 
Ficha catalográfica elaborada pelo

Serviço de Biblioteca e Informaçāo, FZEA/USP, com os dados fornecidos pelo(a) autor(a)

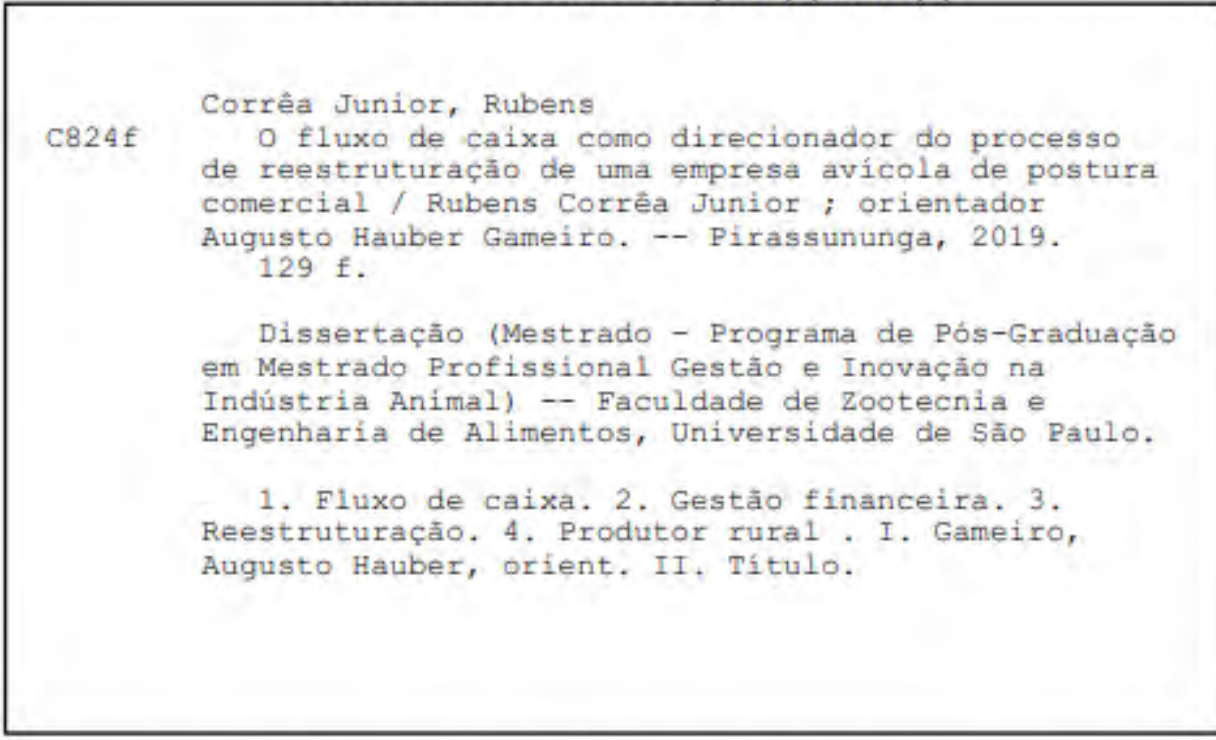

Permitida a copia total ou parcial deste documento, desde que citada a fonte - o autor 


\title{
O fluxo de caixa como direcionador do processo de reestruturação de uma empresa avícola de postura comercial
}

\author{
Dissertação apresentada à Faculdade de \\ Zootecnia e Engenharia de Alimentos da \\ Universidade de São Paulo, como parte \\ dos requisitos para obtenção do título de \\ Mestre em Ciências. \\ Área de Concentração: Gestão e \\ Inovação na Indústria Animal
}

Data de aprovação:

Banca Examinadora:

Prof. Dr. Augusto Hauber Gameiro - Presidente da Banca Examinadora Instituição: Faculdade de Medicina Veterinária e Zootecnia - Universidade de São Paulo

Prof. Dr.

Instituição:

Prof. Dr.

Instituição:

Prof. Dr. Instituição: 


\section{AGRADECIMENTOS}

A Deus, primeiramente, por mostrar o Seu poder e a Sua existência em minha vida.

A meu pai, que em algum momento me deixou aqui na terra para viver a eternidade com Deus. A minha mãe, que deu continuidade no papel de pai e não mediu esforços para garantir minha educação.

A minha amada Stê, que me incentivou e apoiou em todos os momentos em que eu tive a sensação de não conseguir conciliar a pesquisa com o trabalho.

A meus familiares, que tiveram paciência comigo quando deles me ausentei para me dedicar à pesquisa, e rogaram a Deus por mim.

A minha equipe de trabalho que deu todo o suporte e se manteve firme quando eu estive ausente das atividades da empresa durante a pesquisa.

Aos Professores Dr. David Ferreira Lopes Santos, Dr. Lucilio Rogerio Aparecido Alves e Dra. Luciene Rose Lemes, por aceitarem meu convite para a defesa e contribuírem com valiosos apontamentos de melhoria para futuras pesquisas.

Aos colegas do LAE - Laboratório de Análise Socioeconômicas e Ciência Animal e do programa de mestrado profissional GIIA - Gestão e Inovação na Indústria Animal e, em especial, ao amigo Paulo Bertucci, que me falou sobre e incentivou-me a fazer a inscrição para o processo seletivo.

E por fim, ao meu caríssimo Prof. Dr. Augusto Hauber Gameiro, orientador, amigo e mentor que, com sua dedicação, inteligência e paciência, fez com que eu me tornasse um pesquisador. Escutou-me quando eu precisei tomar algumas decisões na minha vida profissional e, com assertividade nos conselhos, fez-me tomar as decisões corretas. Sinto um imenso orgulho por ter sido seu orientando e agradeço, ainda, sua contribuição em minha vivência internacional. 
"True wisdom comes to each of us when we realize how little we understand about life, ourselves, and the world around us." 


\section{RESUMO}

CORRÊA JUNIOR, R. O fluxo de caixa como direcionador do processo de reestruturação de uma empresa avícola de postura comercial. 2019. $129 \mathrm{f}$. Dissertação (Mestrado) - Faculdade de Zootecnia e Engenharia de Alimentos, Universidade de São Paulo, Pirassununga, 2019.

Gerir uma pequena ou média empresa não é uma tarefa fácil para os seus gestores. Quando se trata de pequenos e médios produtores rurais, as dificuldades são ainda maiores para a sobrevivência do negócio. $O$ desafio deles inicia em manter 0 controle de fluxo de caixa muito bem alinhado para se precaver de fatores incontroláveis que possam surgir com a variação de preços da produção agropecuária, condições climáticas, biológicas e outras. Com base em um caso real de um médio avicultor de postura comercial apresentando sérios problemas financeiros, este trabalho propõe aos produtores agrícolas gerirem seus negócios com mais organização e domínio dos resultados utilizando a ferramenta de fluxo de caixa. A pesquisa teve como objetivos: propor um modelo simples e prático de gestão de fluxo de caixa para a tomada de decisão; diagnosticar os problemas que contribuíram para o cenário de crise do empreendimento; e avaliar se apenas com o uso da ferramenta de fluxo de caixa é possível aos produtores rurais gerir seus negócios e tomar as decisões necessárias para obter os resultados esperados. A metodologia escolhida foi a pesquisa ação, na qual o pesquisador possui uma postura direta e ativa sobre a situação-problema. Os resultados encontrados mostraram que por meio da utilização da ferramenta de fluxo de caixa a empresa encerrou o período com um acréscimo de $951,5 \%$ em suas disponibilidades de caixa, gerou $22,5 \%$ de caixa sobre o resultado operacional e manteve seu saldo mínimo de caixa em $23,6 \%$ acima do limite necessário para a operação se manter funcionando com segurança. Com isso, foi possível, a partir do uso da ferramenta de fluxo de caixa, analisar a viabilidade de negócios da empresa e tomar decisões assertivas que reverteram o cenário crítico da empresa e garantiram a sua continuidade. Desta forma, a metodologia proposta pode ser recomendada para outros empreendimentos de pequeno e médio porte no ramo da produção agropecuária.

Palavras-chave: Fluxo de caixa. Gestão financeira. Reestruturação. Produtor rural. 


\begin{abstract}
CORREAA JUNIOR, R. Cash flow as a driver of the restructuring process of a commercial poultry company. 2019. 129 f. Dissertação (Mestrado) - Faculdade de Zootecnia e Engenharia de Alimentos, Universidade de São Paulo, Pirassununga, 2019.
\end{abstract}

Managing a small or medium business is not an easy task for their managers. When it comes to small and medium farmers, the difficulties are even greater regarding business survival. Their challenge starts in keeping cash flow control closely aligned to guard against uncontrollable factors that may arise, such as changing farm prices, weather and biological conditions as well as other factors. Based on a real and concrete case of a medium-sized commercial poultry farmer with serious financial problems, this paper proposes to enable farmers to manage their business in a more organized way, having mastery of results using the cash flow tool. The research aimed at proposing a simple and practical cash flow management model for decision making; diagnosing the problems that contributed to the crisis scenario of the enterprise; and assessing whether only by using the cash flow tool farmers can manage their business and make the necessary decisions to achieve the expected results. The chosen methodology was action research, in which the researcher has a direct and active posture about the problem situation. The results showed that by using the cash flow tool, the company ended the period with an increase of $951.5 \%$ in its cash and cash equivalents, generated $22.5 \%$ of cash on operating income and maintained its minimum balance $123.6 \%$ above the average amount required to keep operating safely. As a result, it was possible through the use of the cash flow tool to analyze the business viability of the company and make assertive decisions that reversed the critical scenario of the company and ensured its continuity. Thus, the proposed methodology can be recommended for other small and medium-sized enterprises in the field of agricultural production.

Keywords: Cash Flow. Financial management. Restructuring. Rural producer. 


\section{LISTA DE FIGURAS}

Figura 1 - Fluxograma do sistema agroindustrial (SAG) do ovo.............................20

Figura 2 - Fluxograma do processo produtivo do ovo ..........................................26

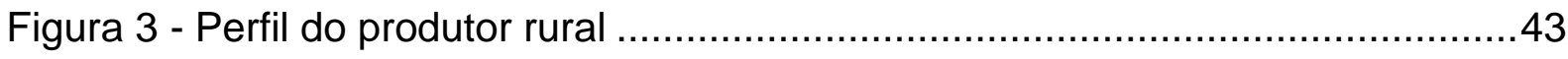

Figura 4 - Fatores praticados pelos empreendedores brasileiros..............................60

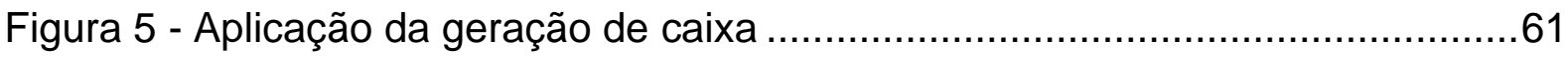

Figura 6 - Etapas de planejamento de caixa ………...........................................67

Figura 7 - Ciclo operacional e de caixa ……...........................................................

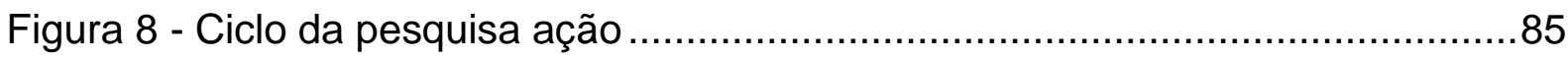

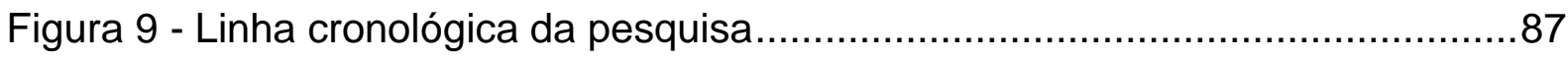

Figura 10 - Tela de lançamento de entradas e saídas do fluxo de caixa implantado

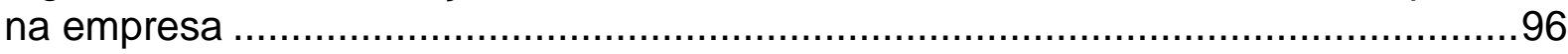

Figura 11 - Demonstrativo dos fluxos de caixa implantado na empresa ...................97

Figura 12 - Organograma antes do uso do fluxo de caixa....................................102

Figura 13 - Análise de SWOT da operação de suínos ……………………..........107

Figura 14 - Análise de SWOT da operação de ovos ………...................................108

Figura 15 - Organograma após o uso do fluxo de caixa......................................112 


\section{LISTA DE GRÁFICOS}

Gráfico 1 - Os dez maiores países produtores agrícolas (em USD).

Gráfico 2 - Os dez maiores países produtores de carne de frango (em mil toneladas)

Gráfico 3 - Os dez maiores países produtores de ovos (em mil toneladas)

Gráfico 4 - Série histórica do preço médio de milho $(\mathrm{R} \$ / \mathrm{Saca}$ de $60 \mathrm{~kg})$ .22

Gráfico 5 - Série histórica do preço médio de farelo de soja ( $\mathrm{R} \$ /$ Tonelada) .22

Gráfico 6 - Série histórica da evolução do preço médio de venda de ovos ( $\mathrm{R} \$ /$ Caixa)

Gráfico 7 - Variação dos Preços de ovos em períodos sazonais ( $\mathrm{R} \$ /$ Caixa) .32

Gráfico 8 - Taxa de mortalidade de empresas abertas em 2010 com até 5 anos .....33

Gráfico 9 - Taxa de mortalidade por porte de empresas com até 2 anos. 34

Gráfico 10 - Taxa de mortalidade de empresas com até 2 anos de operação 35

Gráfico 11 - Taxa de sobrevivência de empresas com até 2 anos de operação ........35

Gráfico 12 - Evolução do PIB no Brasil no período de 2008 a 2014 .36

Gráfico 13 - Evolução trimestral do número de produtores rurais .43

Gráfico 14 - Finalidades do empenho de empréstimos/financiamentos obtidos .45

Gráfico 15 - Proporção de recursos tomados com e sem subsídios do governo .46

Gráfico 16 - Distribuição das receitas - 1ํ Semestre de 2017 111

Gráfico 17 - Distribuição das receitas - Acumulado de 2017 113 


\section{LISTA DE QUADROS}

Quadro 1 - Classificação de ovos comerciais. .25

Quadro 2 - Critério de classificação de empresa pelo BNDES e BACEN .38

Quadro 3 - Critério de classificação de empresa pelo Sebrae 38

Quadro 4 - Critério de classificação de produtora rural segundo a renda

Quadro 5 - Critério de classificação de produtor rural segundo tamanho da propriedade

Quadro 6 - Modelo de Balanço Patrimonial..........................................................50

Quadro 7 - Modelo Demonstração de Resultados do Exercício.................................52

Quadro 8 - Modelo Demonstração de Fluxos de Caixa - Método Direto ...................56

Quadro 9 - Modelo Demonstração de Fluxos de Caixa - Método Indireto .................57

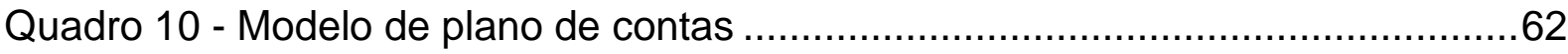

Quadro 11 - Eventos e decisões de capital de giro .................................................68

Quadro 12 - Grupos patrimoniais de capital de giro ……...................................... 72

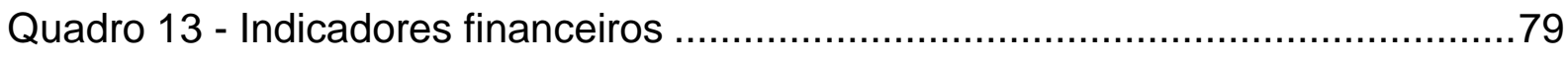

Quadro 14 - Plano de contas implantado na empresa .........................................92

Quadro 15 - Plano de contas da empresa com agrupamento .................................93

Quadro 16 - Mapa de diagnóstico dos principais problemas da empresa ...............104

Quadro 17 - Custo mensal da unidade suína ....................................................106

Quadro 18 - Indicadores financeiros - 1ํ Semestre de 2017 .............................110

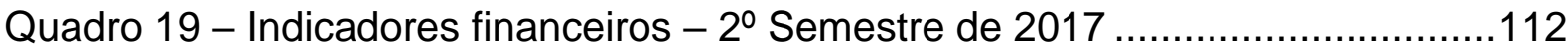

Quadro 20 - Cálculo dos prazos médios da operação …………….....................114 


\section{SUMÁRIO}

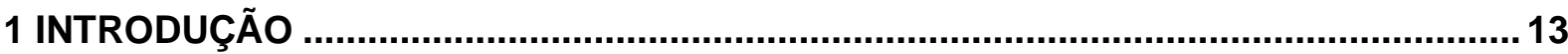

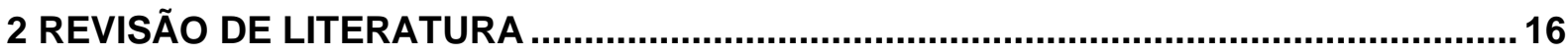

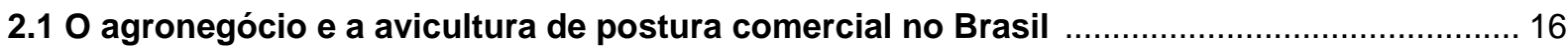

2.1.1 A importância do ovo e o sistema agroindustrial (SAG) ......................................................... 19

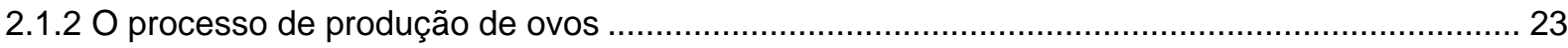

2.1.3 Fatores que influenciam a competividade da avicultura de postura comercial .......................... 26

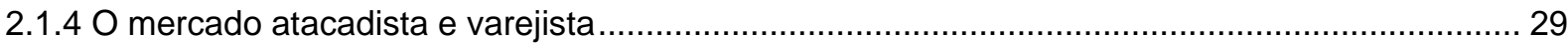

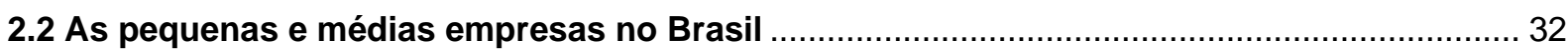

2.2.1 Critérios de classificação da pequena e média empresa ........................................................ 37

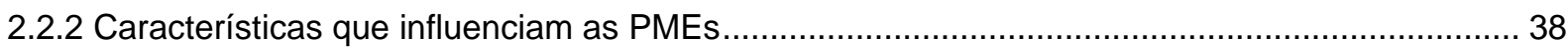

2.2.3 O produtor rural no Brasil - Perfil e caracterização ............................................................. 42

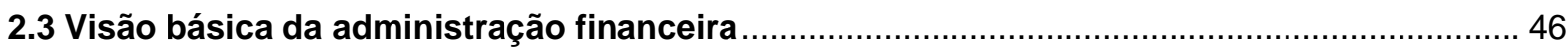

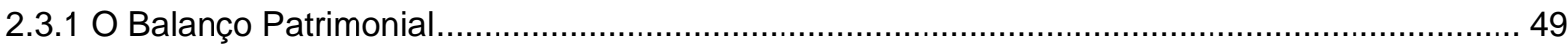

2.3.2 A Demonstração de Resultados do Exercício........................................................................ 51

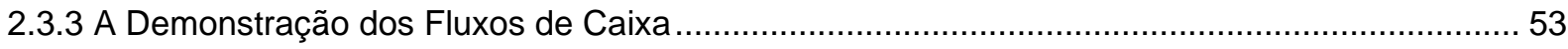

2.4 Fluxo de caixa como ferramenta de gestão para pequenas e médias empresas .................. 58

2.4.1 A importância do plano de contas para estruturar o fluxo de caixa ............................................ 61

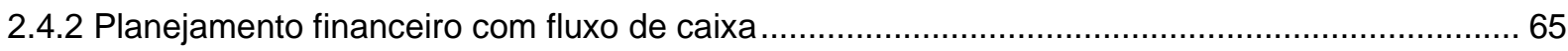

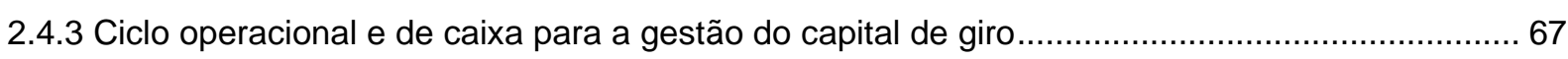

2.4.4 Dimensionamento do capital de giro e cálculo dos prazos médios .......................................... 71

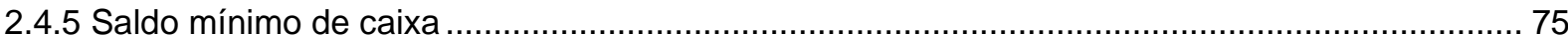

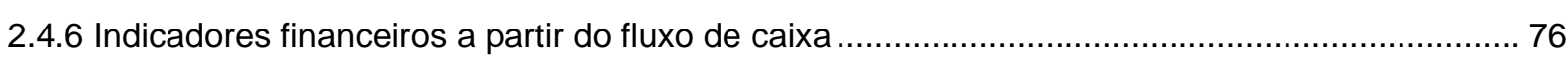

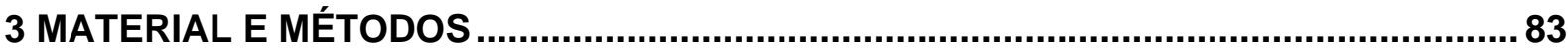

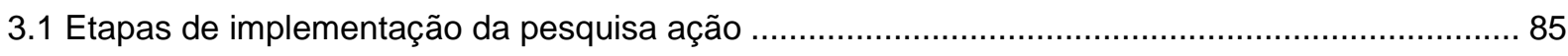

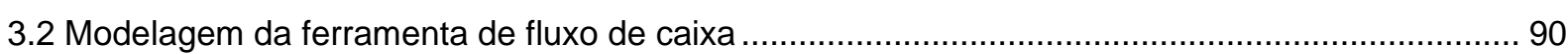

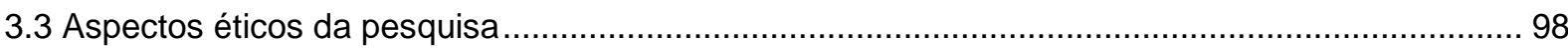

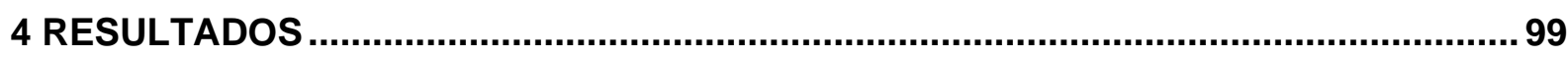

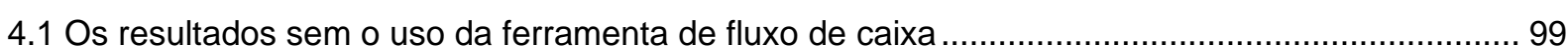

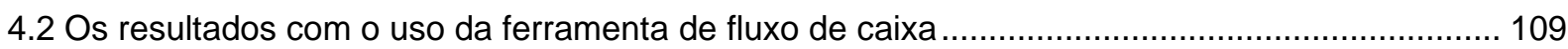

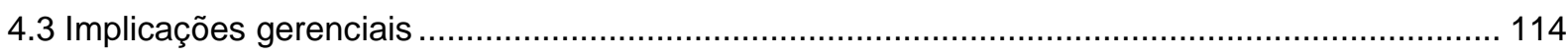

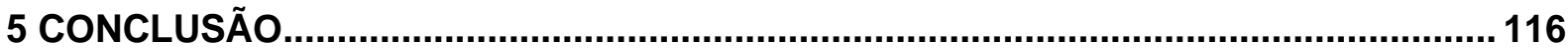

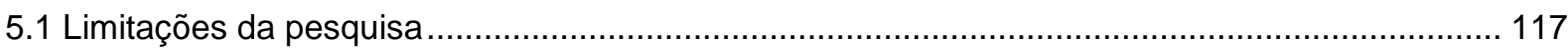

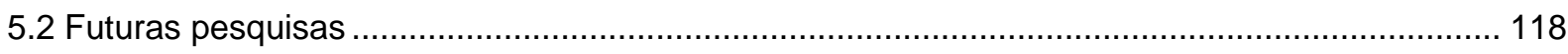

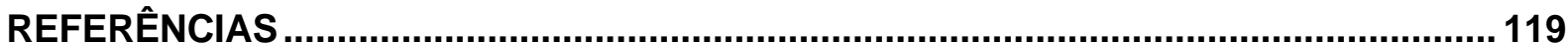

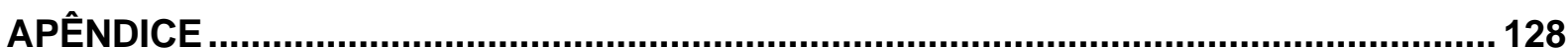




\section{INTRODUÇÃO}

As pequenas e médias empresas são consideradas partes integrantes da economia, porque possuem uma participação relevante no desenvolvimento de um país (BIELIKOVA; MAZANEC, 2016). Com algumas características que as diferem das grandes empresas, as pequenas e médias empresas no Brasil possuem um índice de mortalidade significante.

Segundo o Serviço Brasileiro de Apoio às Micro e Pequenas Empresas Sebrae (2016a) e o Instituto Brasileiro de Geografia e Estatística - IBGE (2017a), as empresas constituídas em 2010 apresentaram uma taxa de mortalidade de 44,4\% e tiveram suas atividades encerradas nos primeiros dois anos. Quando considerado os primeiros cinco anos de funcionamento a partir desse mesmo ano, a taxa de mortalidade se eleva ao patamar de $62,2 \%$. Dentre várias causas para esse resultado, a principal é a falta de rigor no controle de fluxo de caixa.

A gestão do fluxo de caixa provê ao gestor as informações financeiras necessárias para sinalizar uma possível necessidade de dinheiro antecipadamente, a fim de evitar que a empresa fique sem recursos para sustentar sua operação. benefício dessa informação é significativo para as pequenas e médias empresas, pois quando comparadas às grandes empresas, o custo de captação de dinheiro que necessita é maior e a disponibilidade de crédito é mais restrita (GITMAN, 1997; TAURINGANA; AFRIFA, 2013).

Entender os demonstrativos financeiros para tomar decisões é uma tarefa desafiante para os gestores de pequenas e médias empresas - PMEs (MAINGOT; ZEGHAL, 2006). Quando se analisam os pequenos e médios produtores agrícolas, o desafio é ainda maior, pois em sua maioria possuem gestão familiar com pouca formação e conhecimento empresarial (IBGE, 2017b).

Entretanto, os pequenos e médios produtores rurais, mesmo que considerados por questões tributárias pessoas físicas, são empresas que também demandam uma boa gestão da sua propriedade não apenas como um bem da família, mas como um negócio gerador de bons resultados.

A evolução do agronegócio no país como um setor da economia que impulsiona o crescimento do Produto Interno Bruto - PIB, posiciona o Brasil entre os dez maiores países no agronegócio, sendo o quarto maior produtor agrícola, terceiro maior produtor de frango e o sétimo maior na produção de ovos (FOOD AND 
AGRICULTURE ORGANIZATION OF THE UNITED NATIONS - FAO, 2016). Entre os maiores produtores, o segmento de postura comercial no país possui grande relevância para o desenvolvimento econômico. São 163,7 milhões de aves na produção de ovos, produzindo 728 milhões de dúzias de ovos por ano e gerando $\mathrm{R} \$ 10,4$ bilhões para a economia interna (IBGE; 2018). Porém, os desafios para os produtores são grandes com relação à instabilidade de preços dos produtos agrícolas, bem como às variáveis biológicas e climáticas envolvidas na produção.

Portanto, a gestão de fluxo de caixa de um produtor rural precisa estar muito bem alinhada e preparada para a chegada de variáveis incontroláveis a que a atividade está suscetível. Segundo Procópio (1997), a preocupação do produtor deixou de ser o domínio das técnicas de produção e passou a ser a aquisição de habilidades para tomar decisões financeiras que manteria sua produção com 0 menor custo e melhor margem de rentabilidade.

O desenvolvimento dessa pesquisa é justificado pelo fato de pequenas e médias empresas, independente do ramo de atividade, apresentarem uma tendência a tomar decisões estratégicas baseadas na intuição para alcançar um resultado futuro e não conseguirem prever, com a precisão necessária, a continuidade do negócio em curto e médio prazo. A dificuldade de coordenação da atividade de gestão com as rotinas do dia a dia e a falta de controles financeiros são outros pontos importantes que se tornam gargalos ao bom desempenho financeiro dessas empresas (LEONE, 1999).

A ausência de um planejamento focado no desempenho financeiro conduz os gestores a gerenciarem suas empresas de forma não profissionalizada, informal e com escassez de recursos financeiros (LEONE, 1999).

Com base em um caso real de uma granja de postura comercial com fortes dificuldades financeiras, tendo como atividade principal a produção de ovos e como atividade secundária a produção de suínos, este trabalho tem os seguintes objetivos: (i) propor um modelo simples e prático de gestão de fluxo de caixa para a tomada de decisão; (ii) diagnosticar os problemas que contribuíram para o cenário de crise que a empresa estava enfrentando; e (iii) avaliar se apenas com o uso da ferramenta de fluxo de caixa é possível o produtor rural gerir o negócio e tomar as decisões necessárias para obter o resultado esperado.

Como apoio aos objetivos, o embasamento teórico para esse projeto de pesquisa foi estruturado em quatro partes temáticas: (1) O agronegócio e a 
avicultura de postura comercial no Brasil; (2) As pequenas e médias empresas no Brasil; (3) Visão básica da administração financeira e (4) Fluxo de caixa como ferramenta de gestão para pequenas e médias empresas.

Espera-se que esse trabalho venha a contribuir para o conhecimento financeiro e de gestão em pequenos e médios produtores rurais e que possa ser utilizado em estudos futuros para o aprimoramento da ferramenta com integração a outros demonstrativos contábeis de forma simples e prática. 


\section{REVISÃO DE LITERATURA}

Este capítulo contém o referencial teórico que embasará o desenvolvimento da pesquisa. Está estruturado em três tópicos, a saber: as características do agronegócio e da avicultura no Brasil, o comportamento da pequena e média empresa e a visão básica de gestão financeira. Para a revisão de literatura foram utilizados como base de pesquisa artigos científicos, livros, dissertações, teses e publicações empresariais e governamentais.

\subsection{O agronegócio e a avicultura de postura comercial no Brasil}

A história da avicultura no Brasil é marcada com a chegada das caravelas portuguesas de Pedro Álvares de Cabral no ano de 1500. Pero Vaz de Caminha, escrivão oficial daquela expedição, registrou em uma carta a reação do povo recém descoberto ao ver uma galinha (UNIÃO BRASILEIRA DE AVICULTURA - UBABEF, 2011).

Com a chegada das aves no país, a criação de galinhas se fortaleceu com os pequenos produtores para a produção de carne. Com o rápido crescimento populacional no período de 1872 a 1920, a avicultura enfrentou seu primeiro grande desafio: suprir a demanda que crescia de, no mínimo, dez milhões de pessoas para ao menos trinta milhões de pessoas (UBABEF, 2011).

Naquela época o ganho de escala de produção era muito importante para não limitar o crescimento da atividade. Contudo, uma ave demorava seis meses para atingir o peso de abate que era de 2,5 quilos, não sendo suficiente para suprir o consumo acelerado (UBABEF, 2011).

Em meados de 1930, o setor da avicultura foi um dos primeiros a se fortalecer com o ciclo de modernização da economia que o país passou, a fim de diminuir sua dependência econômica nas exportações de café. O estado de São Paulo se destacou nesse período com o desenvolvimento da atividade após a chegada dos imigrantes japoneses, que trouxeram conhecimento e tecnologia para o desenvolvimento da agricultura (UBABEF, 2011; ZEN, 2014).

A produção de ovos animou vários avicultores, que chegavam a exportar parte da produção. Em 1939, o então presidente da época, Getúlio Vargas, assinou 
- Decreto-lei no 3.467 regulamentando a inspeção sanitária, classificação, conservação e a embalagem de ovos destinados à exportação (UBABEF, 2011).

A partir da década de 1960, a avicultura fortaleceu seu desenvolvimento com a entrada de empresas processadoras no mercado disseminando o sistema de integração (parceria entre indústria e produtores) na produção de frangos de corte, o desenvolvimento genético para produzir dois tipos de aves - para corte ou para postura -, técnicas de produção intensiva e transformações tecnológicas que contribuíram para o avanço da atividade e da economia (UBABEF, 2011).

Assim, a evolução do agronegócio brasileiro contribuiu para o crescimento da economia participando com 21,6\% no PIB nacional e impulsionou o crescimento do Brasil em 2017 (CEPEA, 2018; IBGE, 2018a). Segundo dados da FAO (2016; 2013a; 2013b), o Brasil se mantém entre os dez maiores países no agronegócio, sendo o quarto maior produtor agrícola, terceiro maior produtor de carne de frango e o sétimo maior produtor de ovos, conforme demonstrado nos Gráficos 1, 2 e 3.

Gráfico 1 - Os dez maiores países produtores agrícolas (em USD)

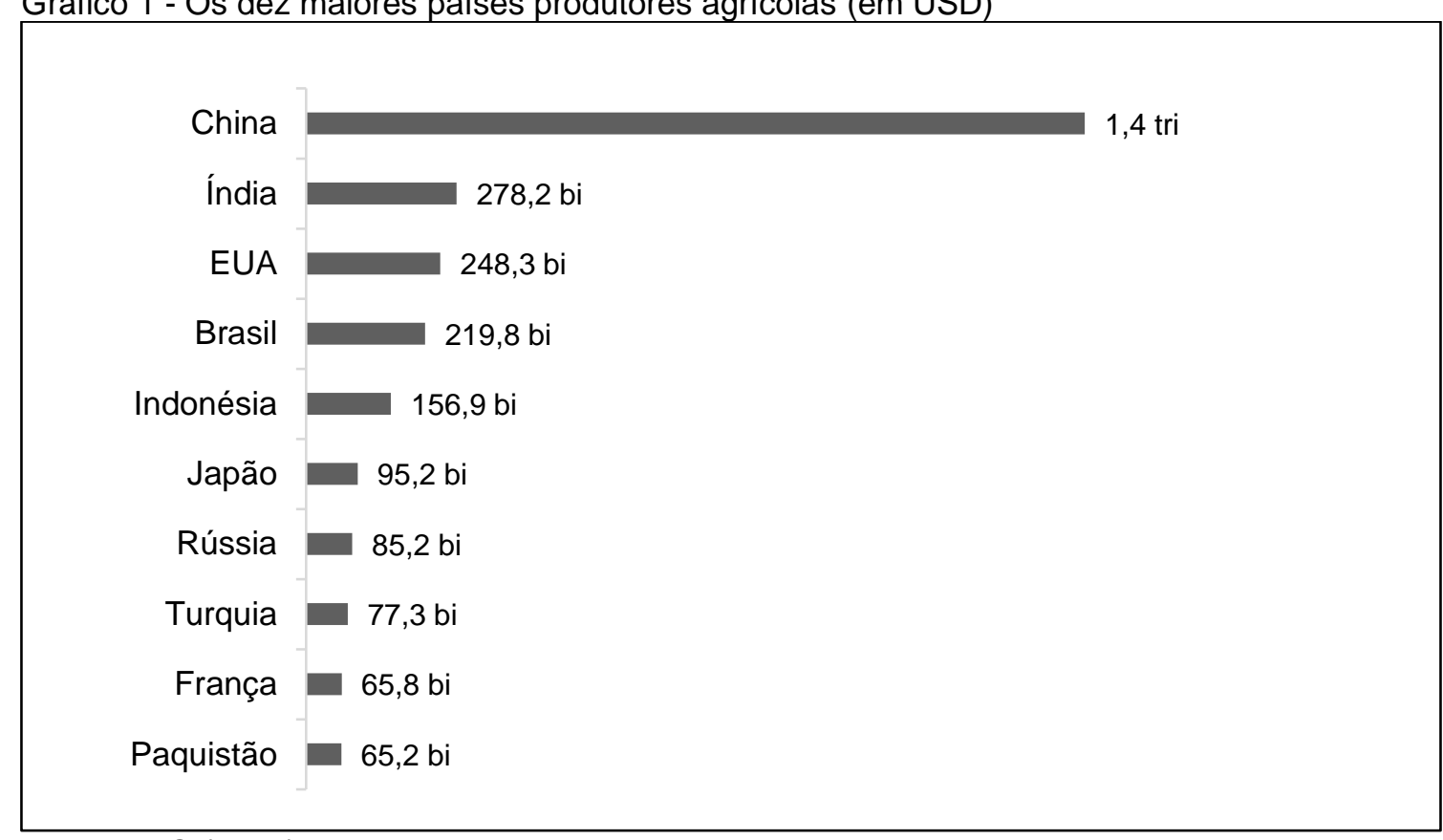

Fonte: FAO (2016). 
Gráfico 2 - Os dez maiores países produtores de carne de frango (em mil toneladas)

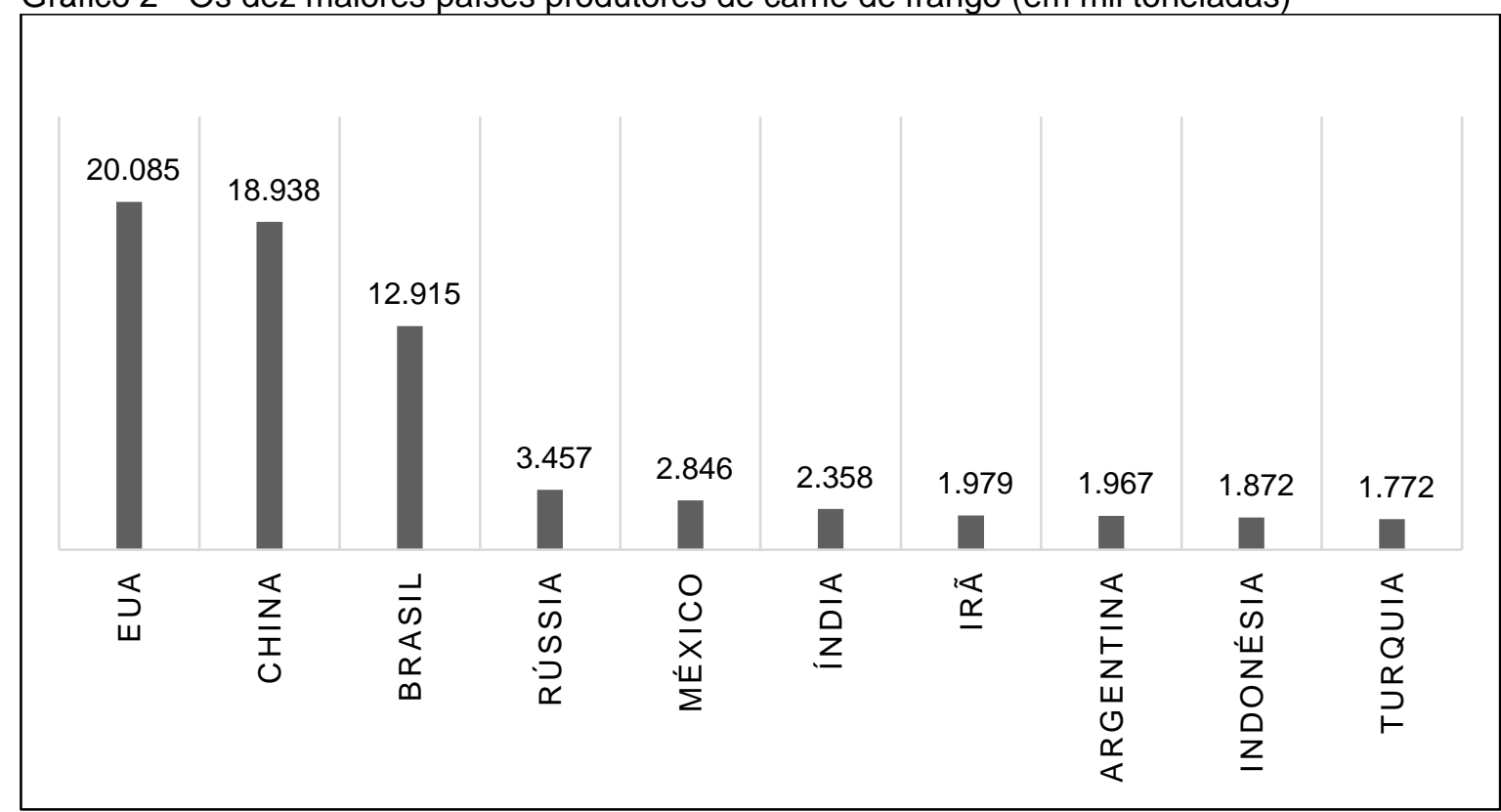

Fonte: FAO (2013a).

Gráfico 3 - Os dez maiores países produtores de ovos (em mil toneladas)

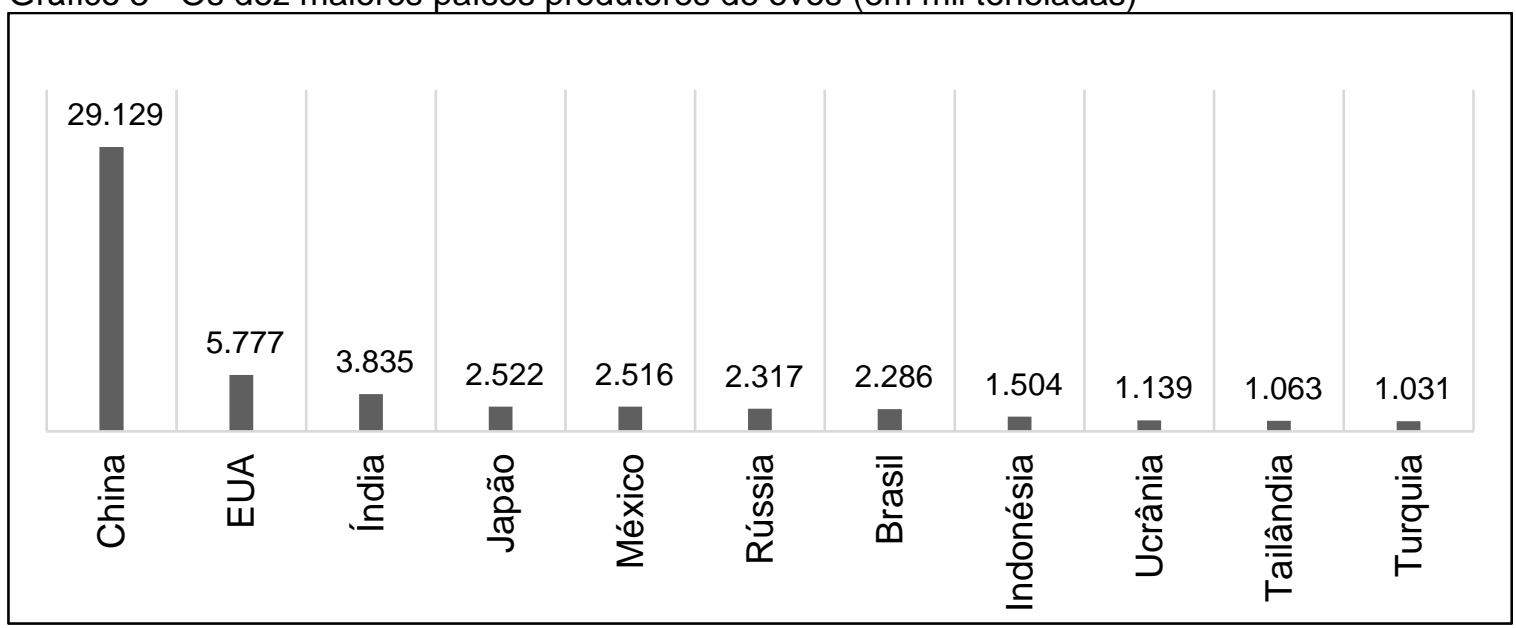

Fonte: FAO (2013b).

No período de 2010 a 2017, a produção de ovos no Brasil cresceu na média de $38,3 \%$ ao ano, encerrando o período com 39,9 bilhões de unidades de ovos produzidos. O consumo de ovos per capita por ano cresceu $29,7 \%$ avançando de 148 ovos/ano/per capita em 2010 para 192 ovos/ano/per capita em 2017 (ASSOCIAÇÃO BRASILEIRA DE PROTEÍNA ANIMAL - ABPA, 2018). Comparado com outros países de menor população, o consumo per capita/ano do Brasil é menor que Argentina (256 ovos), Colômbia (242 ovos), Japão (329 ovos), México (352 ovos), Alemanha (231 ovos), Hungria (214 ovos), entre outros (INTERNATIONAL EGGS COMMISSION - IEC, 2015). 
Segundo dados do IBGE (2018b), o plantel de galinhas poedeiras no país é de 163,7 milhões de aves e a produção de ovos para consumo foi de 728,0 milhões de dúzias. A produção está distribuída em quase todos os estados brasileiros, porém os Estados que se destacam na liderança são: São Paulo $(33,7 \%)$, Espírito Santo $(12,1 \%)$ e Minas Gerais (10,2\%) totalizando 56,0\% da produção nacional. O estado de São Paulo é o líder na produção de ovos graças à região de Bastos, onde se encontra a maior região produtora de ovos do Brasil. Da quantidade produzida, $99,8 \%$ é consumida internamente e apenas 0,2\% é destinada à exportação para diversos países do mundo, com destaque para os maiores importadores de ovos "in natura" e processados (ovo líquido e em pó): Emirados Árabes e Japão (ABPA, 2018).

O Ministério da Agricultura, Pecuária e Abastecimento - MAPA (BRASIL, 2019) mostra que o Valor Bruto de Produção Agropecuária (VPA) encerrou o ano de 2018 em $R \$ 569,8$ bilhões, sendo $R \$ 10,4$ bilhões desse montante referente à produção de ovos, que também apresentou uma média de $\mathrm{R} \$ 12,7$ bilhões no período de 2015 a 2018 na economia do agronegócio brasileiro.

A atividade da avicultura de postura comercial tem apresentado um crescimento com o aumento do consumo de ovos e também pela viabilidade de produção em pequenas e médias propriedades (SOBRINHO; FONSECA, 2007).

\subsubsection{A importância do ovo e o sistema agroindustrial (SAG)}

Considerado como um dos alimentos causadores de colesterol e sendo excluído dos cardápios por um longo período, o ovo reconquistou sua posição na alimentação humana, superando com os seus benefícios todos os aspectos ditos de impacto negativo na saúde e qualidade de vida das pessoas (RIBEIRO; OLIVO, 2017).

No início da década de 1970, a comercialização de ovos sofreu uma grande queda, devido a uma forte campanha para a diminuição do seu consumo, a fim de reduzir os índices de colesterol e doenças cardiovasculares na população. Contudo, com o avanço de novas pesquisas sobre esse tipo de alimento, o ovo passou a ser considerado um importante alimento na dieta para prevenção de doenças cardiovasculares, diabetes, entre outras (RIBEIRO; OLIVO, 2017). 
Para além do incentivo ao consumo de ovos por seus benefícios à saúde, a relação qualidade e preço é outro fator preponderante na comercialização de ovos. O ovo se destaca por ser uma fonte de proteína de menor custo e com excelente valor nutricional, comparado as outras proteínas de origem animal (AMARAL et al., 2016). Para Sobrinho e Fonseca (2007), o mercado consumidor cresce significativamente, gerando grandes expectativas de negócios para os produtores. Porém, a falta de comunicação dos benefícios do produto para o consumidor final pode ser considerada um fator limitante no reconhecimento da importância do ovo na alimentação e, consequentemente, no aumento da demanda.

A produção de ovos depende de um conjunto de insumos compostos por rações, vacinas, medicamentos, genética, instalação, máquinas e equipamentos. Após o processamento, o ovo segue para o mercado, onde será comercializado em casca, por meio de atacadistas e varejistas, ou é industrializado (transformado em líquido ou em pó) para ser posteriormente vendido (AMARAL et al., 2016). O fluxograma da Figura 1 demonstra os processos do sistema agroindustrial de ovos.

Figura 1 - Fluxograma do sistema agroindustrial (SAG) do ovo

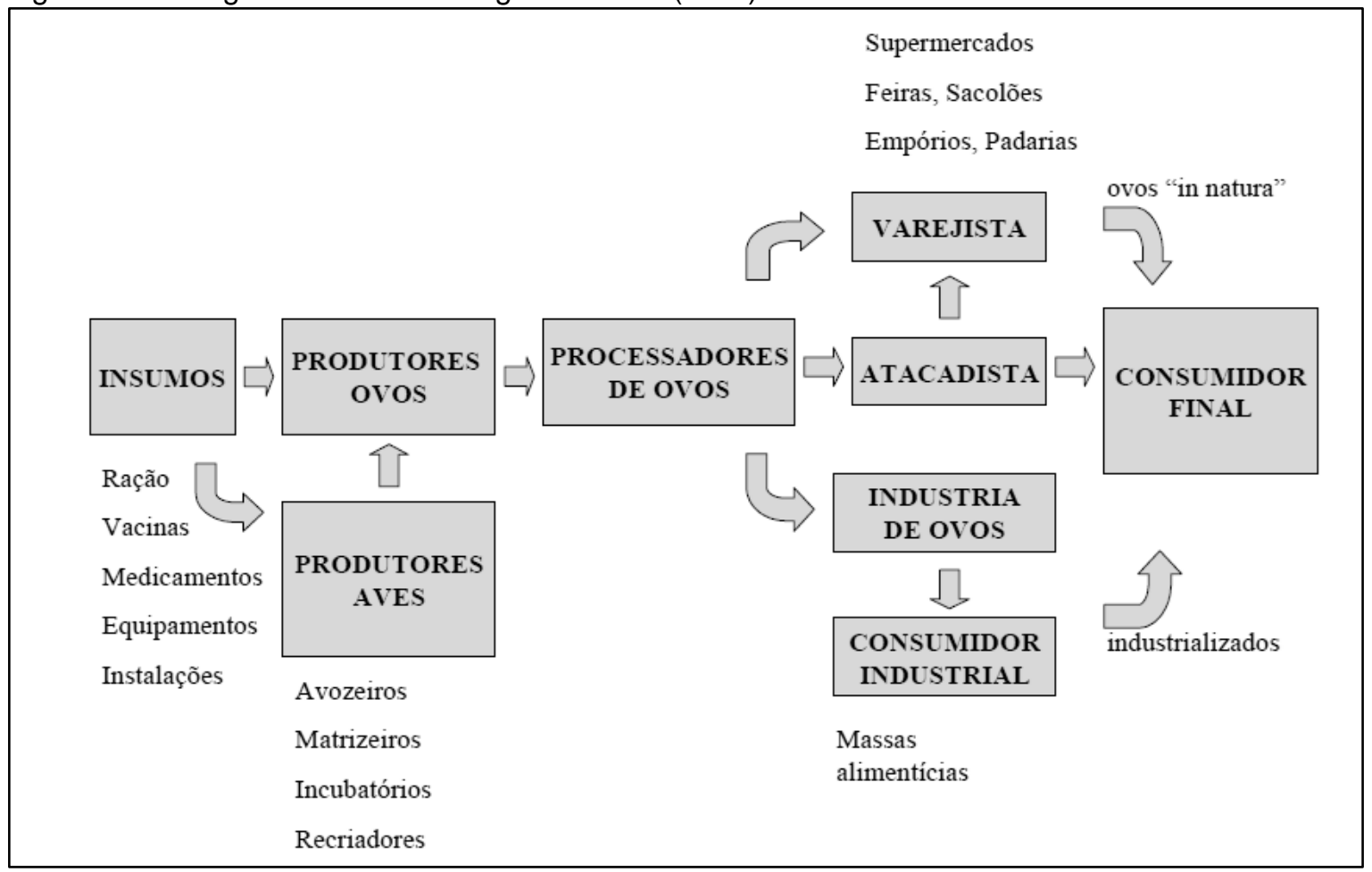

Fonte: MIZUMOTO, F. M. Estratégias nos canais de distribuição de ovos: análise dos arranjos institucionais simultâneos. 2004. 95 f. Dissertação (Mestrado em Administração) - Faculdade de Economia, Administração e Contabilidade, Universidade de São Paulo, São Paulo, 2004. 
A definição da genética da ave é um fator de grande relevância na produção de ovos. Muito embora a cor dos ovos (brancos ou vermelhos) pode ser considerada uma seleção inicial da linhagem a ser utilizada na produção, a definição da linhagem pode influenciar a capacidade de produção das aves, o consumo de ração, a resistência à doenças, a qualidade e outros fatores (AMARAL et al., 2016).

Os produtores de aves são empresas multinacionais que fornecem as pintainhas para os produtores de ovos, possibilitando aos últimos a renovação do plantel. Na década de 1990, o setor de matrizes passou por um processo de concentração, e, atualmente, apenas três grandes empresas de genética de postura comercial se destacam mundialmente: a americana Hy-Line, a holandesa Hendrix Genetics e a francesa Grimaud. Tanto a empresa americana Hy-line quanto a holandesa Hendrix possuem avozeiro e matrizeiro no Brasil. A Hendrix destaca-se ainda por possuir as linhagens ISA, Shaver, Hisex, Dekalb, Bovans e Babcock (AMARAL et al., 2016; MIZUMOTO, 2004).

Outro fator influente na produção de ovos é seu custo. De fato, a ração é o principal insumo com maior custo no sistema agroindustrial do ovo, correspondendo entre $65 \%$ a $70 \%$ de seu custo total (SOBRINHO; FONSECA, 2007). Sua composição corresponde a $60,0 \%$ de milho ou substituto (sorgo e/ou milheto), $23,0 \%$ de farelo de soja, $6,0 \%$ de farinha de carne, $8,0 \%$ de calcário e 3,0\% de outros nutrientes. Portanto, o milho e o farelo de soja são os insumos da ração de maior importância com relação ao custo (AMARAL et al., 2016; KAKIMOTO, 2011).

Nos Gráficos 4 e 5, está demonstrada a variação de preços, em valores nominais, desses dois insumos no período de cinco anos, segundo CEPEA (2019a; 2019c). 
Gráfico 4 - Série histórica do preço médio de milho $(\mathrm{R} \$ / \mathrm{Saca}$ de $60 \mathrm{~kg})$

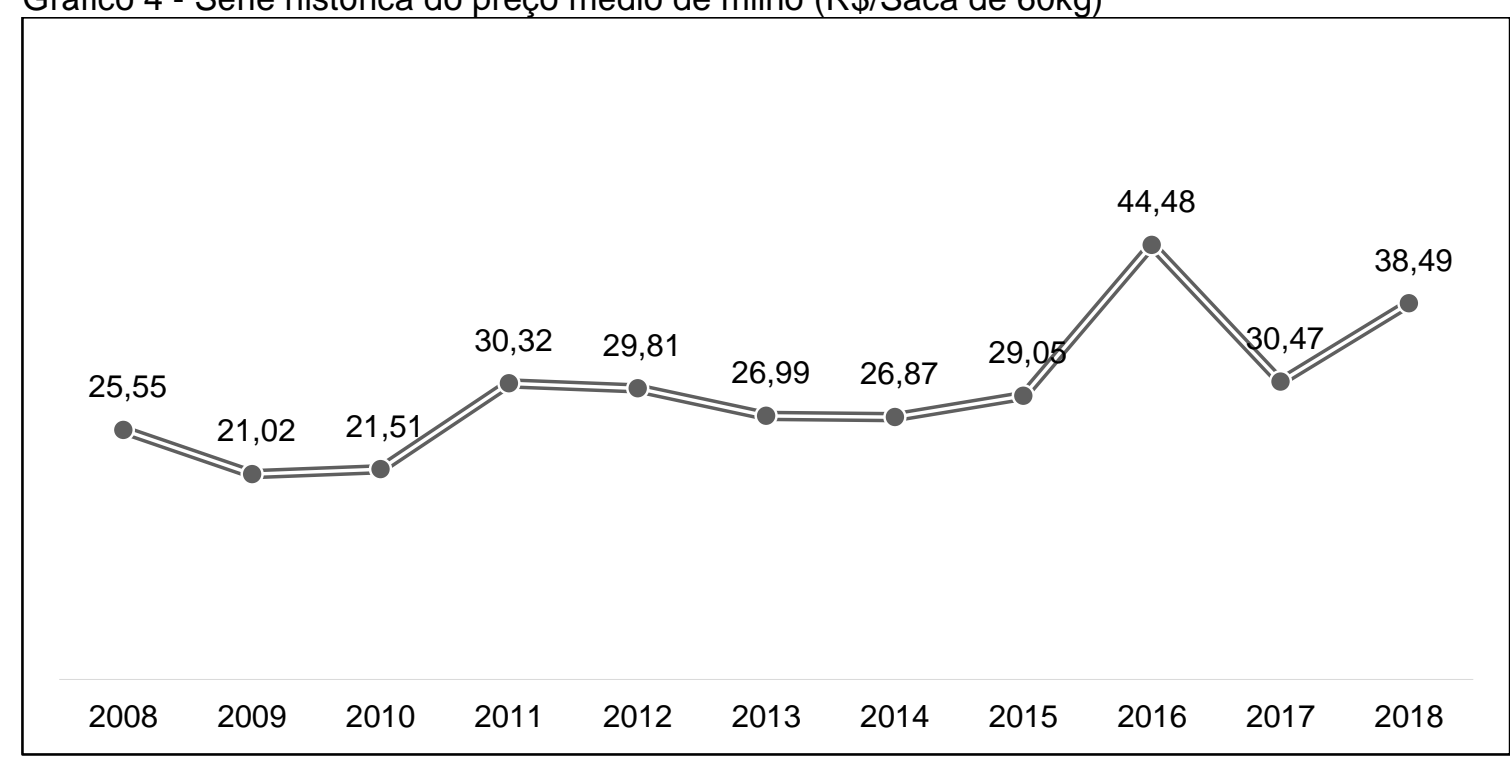

Fonte: CEPEA (2019a).

Gráfico 5 - Série histórica do preço médio de farelo de soja (R\$/Tonelada)

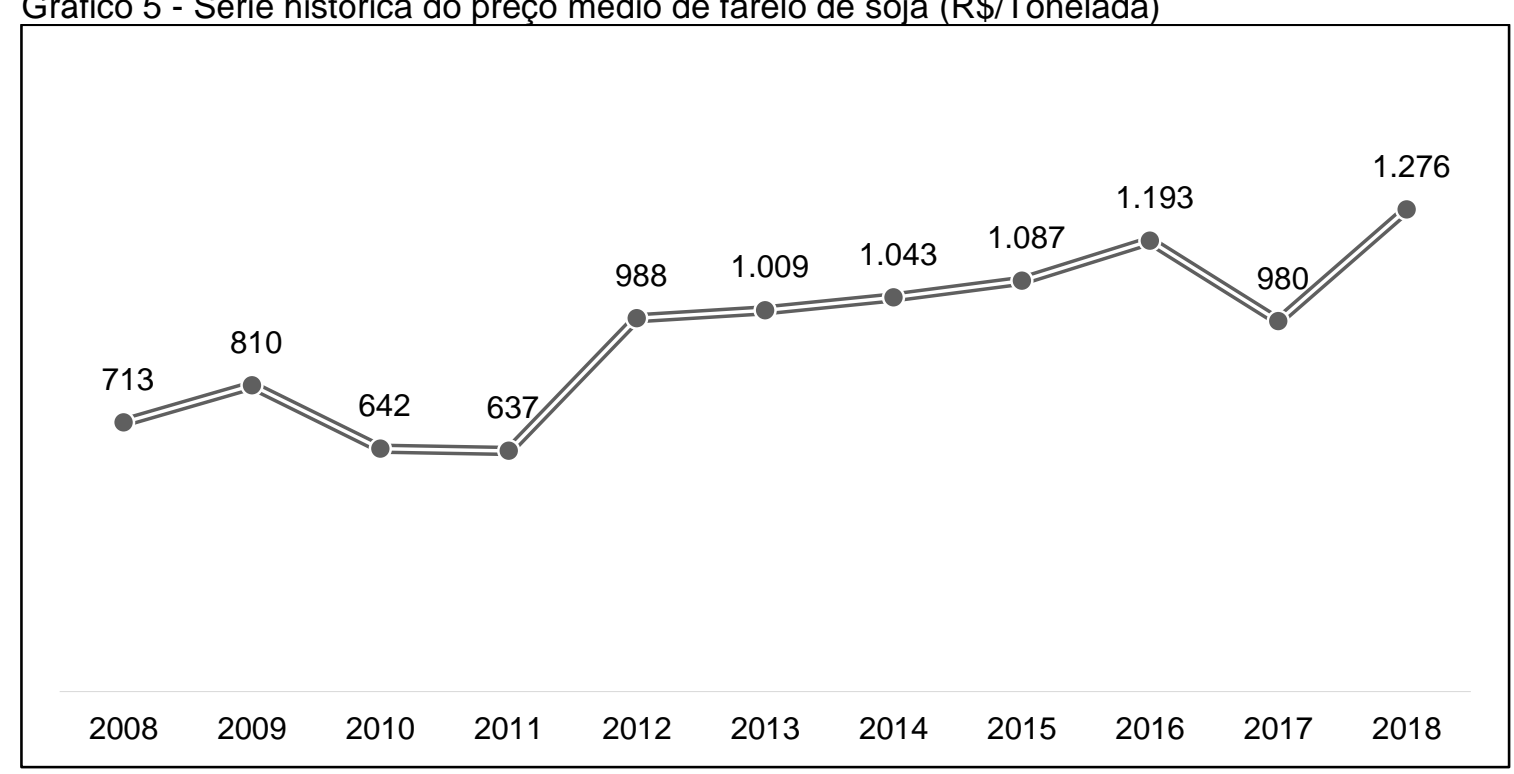

Fonte: CEPEA (2019b).

Por questões de custo e controle de qualidade, a maior parte dos produtores preparam a ração na própria propriedade. Pequenas alterações nas fórmulas com substituição de produtos podem diminuir o custo da ração e dar bons resultados ao produtor, uma vez que este não possui domínio sobre os insumos de maiores concentrações. A ração quando não bem preparada pode afetar a saúde das aves e a qualidade do ovo (AMARAL et al., 2016; KAKIMOTO, 2011).

As indústrias de vacinas e medicamentos, geralmente, são fornecedoras também de núcleos vitamínicos e minerais que são adicionados à ração e se 
caracterizam por um mercado de alto grau de concentração de empresas que, em sua maioria, são multinacionais. Os processadores de ovos podem ser o próprio produtor ou empresas que recebem os ovos, realizam o processamento e distribuem no mercado varejista, atacadista e para a indústria de ovos. A indústria de ovos pertence na sua grande maioria aos processadores (AMARAL et al., 2016).

O esterco, a casca de ovo, quirela de milho e o descarte das aves podem ser considerados parte do elo da cadeia produtiva, que, por sua vez, fomenta a indústria de fertilizantes, frigoríficos e indústria de rações animais (AMARAL et al., 2016).

Por fim, a indústria de maquinários e equipamentos, bem como a de embalagens fornece ao produtor a estrutura necessária para a produção, o processamento, o acondicionamento e a conservação dos ovos (AMARAL et al., 2016).

\subsubsection{O processo de produção de ovos}

O processo de produção de ovos ocorre em diversas etapas. Inicia-se com a aquisição de pintainhas de um dia de vida que ficam alojadas até 120 dias em locais preparados para recria. Após esse período, as frangas formadas substituirão as galinhas velhas, que irão para descarte (KAKIMOTO, 2011).

Durante o período de recria, as aves recebem tratamentos especiais com ração específica para o crescimento, cuidados sanitários, vacinação, limpeza e mão de obra dedicada para esse período. Os cuidados nessa fase são importantíssimos para garantir a formação do lote com qualidade e saúde das aves (KAKIMOTO, 2011).

Nessa fase, há o manejo da debicagem, que é o processo de corte do bico, a fim de evitar o canibalismo e não permitir que a galinha ao se alimentar escolha os ingredientes misturados na ração. Ao final do ciclo de recria, as aves são transferidas para os locais de produção que poderão ser alojadas em gaiolas ou em sistema livre de gaiolas com ninhos (cage free) (KAKIMOTO, 2011).

$\mathrm{Na}$ fase inicial de produção, as galinhas estão com aproximadamente 17 semanas de vida e recebem ração com maior teor de proteína e energia, devido ao desenvolvimento corporal. Os ovos de início de produção são pequenos e comercialmente possuem valores de venda baixos. Após a 50ª semana de vida, a 
ração é dosada com uma quantidade menor de proteína e energia devido ao consumo maior de ração (KAKIMOTO, 2011).

Alguns produtores investem em ingredientes na ração que possuem maior desempenho zootécnico após a 70ª semana de vida. Nessa idade, as aves estão financeiramente amortizadas, mas com uma boa produção, sendo assim compensatório o investimento na ração para melhorar a qualidade da casca, da clara e da gema (KAKIMOTO, 2011).

A quantidade de luz artificial nos galpões de produção após o período de luz natural é outro fator importante. A luz artificial estimula as aves a comerem ração e produzirem hormônios de produção de ovos, aumentando dessa forma o consumo de ração. A viabilidade zootécnica de uma galinha para a produção de ovos pode ser de até 90 semanas de idade, podendo ser prolongada em até 120 semanas com um processo chamado "muda forçada" (KAKIMOTO, 2011).

A "muda forçada" é um processo de renovação do aparelho reprodutor da ave realizado a partir da $80^{\mathrm{a}}$ semana de vida. Durante 10 a 12 dias, as aves não recebem ração e durante um dia não recebem água. O processo todo dura aproximadamente 28 dias e as aves trocam as penas e perdem peso. O objetivo da "muda forçada" é aumentar a qualidade do ovo, que diminui com a idade das galinhas, e é feito se o produtor decidir realizar o processo com base no preço de venda do ovo. Se o preço estiver muito baixo, a decisão mais comum é o descarte das aves (FASSARELA; COVRE, 2010; LAGATTA, 2014).

A coleta de ovos é realizada diariamente nos galpões de produção e podem ser feitos manualmente, acondicionando em bandejas, ou de forma automatizada, com esteiras transportadoras que coletam os ovos e os encaminham para a sala de classificação (KAKIMOTO, 2011).

A sala de classificação, também denominada de entreposto, é o local onde os ovos são lavados, selecionados, classificados por tipo de peso e embalados para a comercialização. As instalações e os equipamentos desse setor são normatizados pelo Regulamento de Inspeção Industrial e Sanitária de Produtos de Origem Animal (RIISPOA) que também se aplica à fabricação de conservas de ovos, estabelecimentos de recebimentos e industrialização de ovos (LAGATTA, 2014).

Na máquina de classificação, os ovos passam pela ovoscopia, processo em que seleciona por meio de uma luz os ovos trincados, com casca fina e com pequenas quebras. Além dessa seleção de qualidade, os colaboradores também 
separam ovos que são sujos durante o processo de produção. Os ovos que não se enquadram na qualidade de comercialização são considerados de segunda linha e têm como destino a indústria de ovos (KAKIMOTO, 2011).

Os ovos que apresentam fissuras maiores ou estão com a casca quebrada, mas com a membrana interna intacta sem vazamento, são quebrados e suas claras e gemas são coletadas e armazenadas em baldes para fornecimento também para a indústria de ovos (KAKIMOTO, 2011).

Segundo Kakimoto (2011), a classificação dos ovos para a comercialização é regulamentada pelo Ministério da Agricultura e Pecuária e possui seis tipos de ovos de acordo com o peso, conforme demonstrado no Quadro 1.

Quadro 1 - Classificação de ovos comerciais

\begin{tabular}{|cc|}
\hline TIPO DE OVOS & PESO \\
\hline Jumbo & Acima de $65 \mathrm{~g}$ \\
Extra & De 60 a $65 \mathrm{~g}$ \\
Grande & De 55 a $60 \mathrm{~g}$ \\
Médio & De 50 a $55 \mathrm{~g}$ \\
Pequeno & De 45 a $50 \mathrm{~g}$ \\
Industrial & Abaixo de $45 \mathrm{~g}$ \\
\hline
\end{tabular}

Fonte: KAKIMOTO, S. K. Fatores críticos da competitividade da cadeia produtiva do ovo no estado de São Paulo. 2011. 156 f. Dissertação (Mestrado em Engenharia de Produção) Universidade Federal de São Carlos, São Carlos, 2011.

A validade do ovo para consumo humano deve ser, segundo o Ministério da Agricultura e Pecuária, no máximo 30 dias em local fresco e 15 dias em temperatura ambiente. O processo de lavagem também segue a normativa do Ministério que determina que a água deve estar entre 35 a 45 graus Celsius e conter sanitizantes (KAKIMOTO, 2011).

Após a processo de classificação, os ovos são embalados e armazenados em local separado da armazenagem dos ovos que estão aguardando a classificação. Para a comercialização é necessário obter a certificação de algum órgão de inspeção sanitária em âmbito federal, estadual ou municipal (KAKIMOTO, 2011).

Portanto, o fluxo de produção de uma granja de postura comercial pode ser representado desde o processo de recria, fábrica de ração, produção de ovos, sala de classificação, comercialização, até geração de receitas com subprodutos, conforme demonstrado na Figura 2. 
Figura 2 - Fluxograma do processo produtivo do ovo

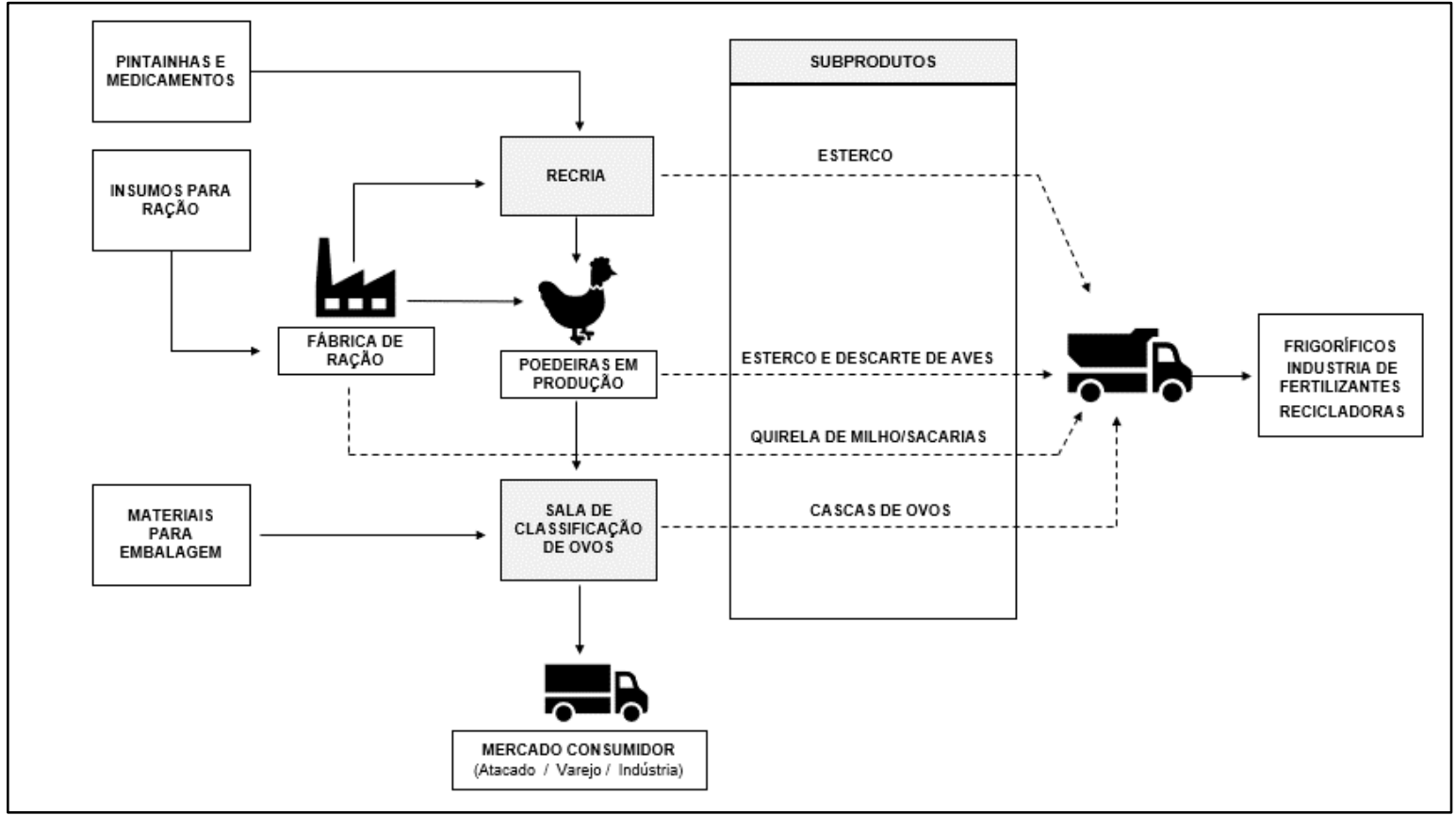

Fonte: Própria autoria.

2.1.3 Fatores que influenciam a competividade da avicultura de postura comercial

Segundo Schwartz e Gameiro (2017), os custos de produção, a diferenciação de produtos no mercado, o manejo zootécnico e a gestão do negócio influenciam no resultado econômico do sistema de produção de ovos. Os autores apontam a importância da gestão financeira com relação à administração do capital para investir na manutenção e na renovação da infraestrutura que não é mensurada pelos produtores, fazendo com que o grau de sucateamento das instalações de produção seja elevado.

Mizumoto (2004) identifica três grupos estratégicos no sistema agroindustrial de ovos que influenciam a competitividade do setor. O primeiro grupo está relacionado às empresas de diferentes escalas de produção e com foco na atividade produtiva de ovos. Foi identificado que a gestão de custos é estratégica para os resultados dessas empresas quando o produtor planeja o período de compra de insumos e administração de estoques. O perfil desse grupo é formado por empresas tradicionais que apresentam instalações antigas e totalmente depreciadas.

O segundo grupo está relacionado à venda e à distribuição de ovos no mercado. As empresas desse grupo buscam atender o varejo, em especial os supermercados. Diferenciam-se das empresas tradicionais no quesito de 
posicionamento e diferenciação do produto e de marcas nas gôndolas dos supermercados. O perfil desse grupo é formado por empresas pertencentes ao primeiro grupo e também por empresas apenas de comercialização e distribuição de ovos (MIZUMOTO, 2004).

O terceiro grupo estratégico no sistema agroindustrial do ovo está relacionado a novas empresas que entraram nesse mercado. Essas empresas caracterizam-se pelo alto investimento em instalações e equipamentos modernos, cujo produto não tem contato manual, desde a produção até o processamento, e apresentam grande escala de produção. Devido ao tamanho da operação, essas empresas focam na gestão de estoque de insumos e na comercialização, a fim de garantir o fluxo dos processos (MIZUMOTO, 2004).

Ainda sobre a gestão de custos, os insumos de ração é a grande conta mensal em uma granja de postura comercial. Entretanto, o controle dos registros financeiros e físicos da propriedade garantem a competividade seja da pequena, média ou grande granja de ovos. Porém, a grande maioria das propriedades avícolas do Brasil não possui registros físicos e financeiros, e quando possui, as informações não estão estruturadas num modelo que facilite a leitura e a análise destas (LAGATTA, 2014).

Além do fator de custos, a sanidade e o controle de qualidade são pontos que influenciam a competitividade da atividade. A implantação de programas de biossegurança, juntamente com as boas práticas de manejo no aviário, garantem a qualidade e a eficiência de produção do plantel (AMARAL et al., 2016).

Para isso, faz-se necessário implementar políticas nas propriedades, que abranjam desde a preparação do local que receberá as galinhas, a capacitação da mão de obra, até o processo de esterilização dos produtos processados. A contaminação de uma granja com doenças pode trazer resultados catastróficos para o negócio e comprometer sua continuidade econômica (AMARAL et al., 2016).

Assim, para Kakimoto (2011) existem sete direcionadores de competividade que influenciam a avicultura de postura. Podem ser classificados como controláveis pela empresa, controláveis pelo governo, quase controláveis e não controláveis para fatores naturais e climáticos. Os direcionadores são classificados em:

1. Gestão da empresa: controlável pela empresa, abrange o uso correto de ferramentas de gestão que permite ao avicultor os controles de produção, zootécnicos, qualidade, financeiros, logística, entre outros. Também são 
controláveis pela empresa a identificação de gargalos de processos, a tomada de decisão com menores riscos, o planejamento de longo prazo, o aumento da participação de mercado e a redução de custos (KAKIMOTO, 2011).

2. Tecnologia: controlável pela empresa, a adoção de tecnologia aplicada no processo ou no produto pode se tornar um instrumento de competição primordial para o produtor permitindo a redução de custos, tempo de produção, mão de obra, ganho de eficiência da logística interna e externa do negócio (KAKIMOTO, 2011).

3. Insumos: considerado quase controlável pela empresa, os insumos na cadeia de produção de ovos são representados pelas matérias-primas da ração, as pintainhas, os medicamentos e vacinas, as embalagens, os equipamentos, a mão de obra, entre outros. Entretanto, é importante o produtor considerar a oferta de produtos agrícolas (milho, sorgo, milheto, farinhas, farelos), os preços, a logística dos mesmos para o local de consumo, com o intuito de garantir o melhor custo para a ração (KAKIMOTO, 2011).

4. Estrutura de mercado: também considerada quase controlável pela empresa, a estrutura de mercado está relacionada à forma que o mercado está organizado em termos de oferta e demanda. O produtor necessita entender fatores que contribuem para uma maior rentabilidade, tais como a capacidade da empresa em inovar sempre; a possibilidade de obter tecnologia não disponível para a concorrência; a capacidade de reter os melhores colaboradores; a promoção de uma marca com excelência e parcerias com fornecedores e clientes; políticas governamentais que dificultam a entrada de novos competidores; o acesso a fontes de financiamentos com melhores taxas e condições de pagamentos; acesso a melhor infraestrutura perante a concorrência, entre outros fatores (KAKIMOTO, 2011).

5. Infraestrutura: considerada quase controlável pela empresa e controlável pelo governo. A infraestrutura pode ser de natureza privada ou pública. Ela está relacionada a transporte, armazéns gerais, comunicação, energia elétrica e tecnologia. A infraestrutura com armazenagem e transporte interfere significativamente na competitividade. O milho e outros produtos da ração apresentam sazonalidade e oscilação nos preços no período de safra e entressafra. Assim, nem sempre é possível armazenar toda a quantidade de 
consumo no ano e, por isso, os armazéns privados e públicos são necessários para assegurar os preços agrícolas, assim como os custos (KAKIMOTO, 2011).

6. Governança de cadeia: quase controlável pela empresa, a governança de cadeia está relacionada a mecanismos de proteção econômica entre agentes de negócios. Os agentes de negócios utilizam de instrumentos apropriados para dar segurança a uma determinada transação devido à incerteza futura do ambiente em que se processa a transação. A governança harmoniza o fluxo de informações, produtos e recursos financeiros ao longo da cadeia produtiva (KAKIMOTO, 2011).

7. Ambiente institucional: controlável pelo governo, o ambiente institucional está relacionado a mais de um fator, entre eles, política de preço mínimo, reforma agrária, política de segurança alimentar, direito de propriedade de terra, tributação, entre outros elementos que influenciam a competitividade do setor (KAKIMOTO, 2011).

\subsubsection{O mercado atacadista e varejista}

De acordo com o sistema agroindustrial do ovo (SAG), a distribuição de ovos para o consumidor final é feita por meio do canal varejista e atacadista. O canal varejista adquire a mercadoria diretamente do entreposto ou do atacadista e a distribuição dos ovos ao consumidor final é realizada por hipermercados, supermercados, feiras, vendedores ambulantes, varejão e sacolão (MIZUMOTO, 2004).

Em redes de supermercados, o abastecimento de ovos nas gôndolas é realizado pela própria granja ou por atacadistas que mantêm promotores no local de venda para a troca de ovos quebrados, vencidos e reposição. O abastecimento em mercados menores é de responsabilidade do próprio comerciante que geralmente adquire a mercadoria com os atacadistas ou no CEASA (MIZUMOTO, 2004).

Os varejistas têm preferências por tipos de ovos que o produtor, dependendo da idade do plantel, não tem condições de entregar e o canal atacadista consegue atender essa demanda, uma vez que adquire a produção de várias granjas (LAGATTA, 2014). 
Os contratos comerciais são utilizados pelas grandes redes de supermercados que, na maior parte das vezes, não determina preço e quantidade no contrato. Os contratos comerciais podem existir apenas para dados cadastrais ou para fornecimento com exclusividade. As compras são realizadas semanalmente por tomada de menor preço entre os fornecedores cadastrados (MIZUMOTO; ZYLBERSZTAJN, 2008).

Alguns produtores buscam o fornecimento para as grandes redes de supermercados devido à segurança e a reputação do cliente no mercado. Em contrapartida, são obrigados a conceder descontos, bonificações, prazos e patrocínios para a abertura de novas lojas, enquanto outros produtores podem recusar esse tipo de negociação (MIZUMOTO; ZYLBERSZTAJN, 2008).

Os preços de vendas dos ovos são dados por cotações diárias eletrônicas por empresas como Ovoonline, Mercado do Ovo e Jox Assessoria. Existem outros canais de publicação do preço de venda para o produtor, porém esses são referências no mercado comercial. A empresa Ovoonline é formada por um conjunto de produtores que estão monitorando o mercado local e publica o preço real do dia e as demais empresas publicam o preço do ovo do dia anterior (KAKIMOTO, 2011).

Os produtores não determinam uma tabela de preço de venda para varejistas e atacadistas, pois a quantidade, qualidade, tamanho, cor e produtos especiais influenciam no momento da negociação. O preço do ovo é altamente determinado pela oferta e demanda e o mercado é responsável pelo equilíbrio do preço de venda de cada tipo de ovo (KAKIMOTO, 2011).

O Gráfico 6 demonstra a evolução de preços de ovos, em valores nominais, no período de cinco anos, tendo como base de referência a região produtora de Bastos/SP, segundo dados do CEPEA (2019b). 
Gráfico 6 - Série histórica da evolução do preço médio de venda de ovos (R\$/Caixa)

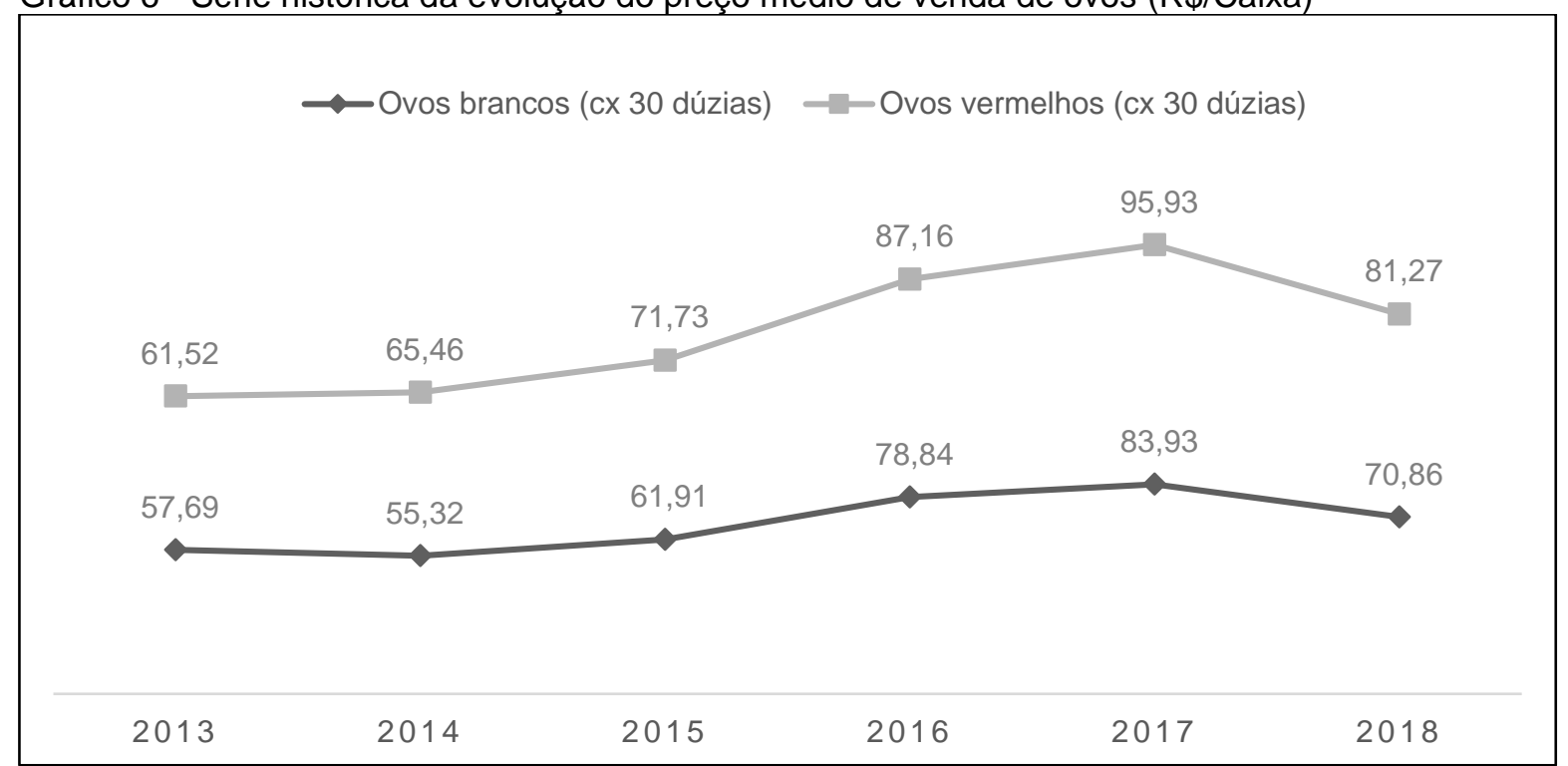

Fonte: CEPEA (2019b).

Ainda de acordo com Kakimoto (2011), as empresas avícolas produtoras de pintainhos de um dia para postura comercial e frango de corte lançam ovos in natura férteis no mercado no momento em que há muito frangos ou pintainhas de postura no mercado.

Esses ovos têm como destino a indústria de ovos, que também consome ovos das granjas de postura comercial. Quando a indústria consome a oferta de ovos férteis no mercado, o preço da caixa de ovo nas granjas de postura comercial tende a cair, devido à dificuldade do produtor em escoar a produção para a indústria (KAKIMOTO, 2011).

Tanto o mercado varejista quanto a indústria de ovos possuem sazonalidade no consumo diminuindo em períodos de férias escolares e coletivas e aumentando em datas comemorativas como natal, quaresma, dia das mães, dias dos pais e outros (KAKIMOTO, 2011), conforme demonstrado no Gráfico $7 \mathrm{com}$ os dados do CEPEA (2019b). 
Gráfico 7 - Variação dos Preços de ovos em períodos sazonais ( $\mathrm{R} \$ / \mathrm{Caixa})$

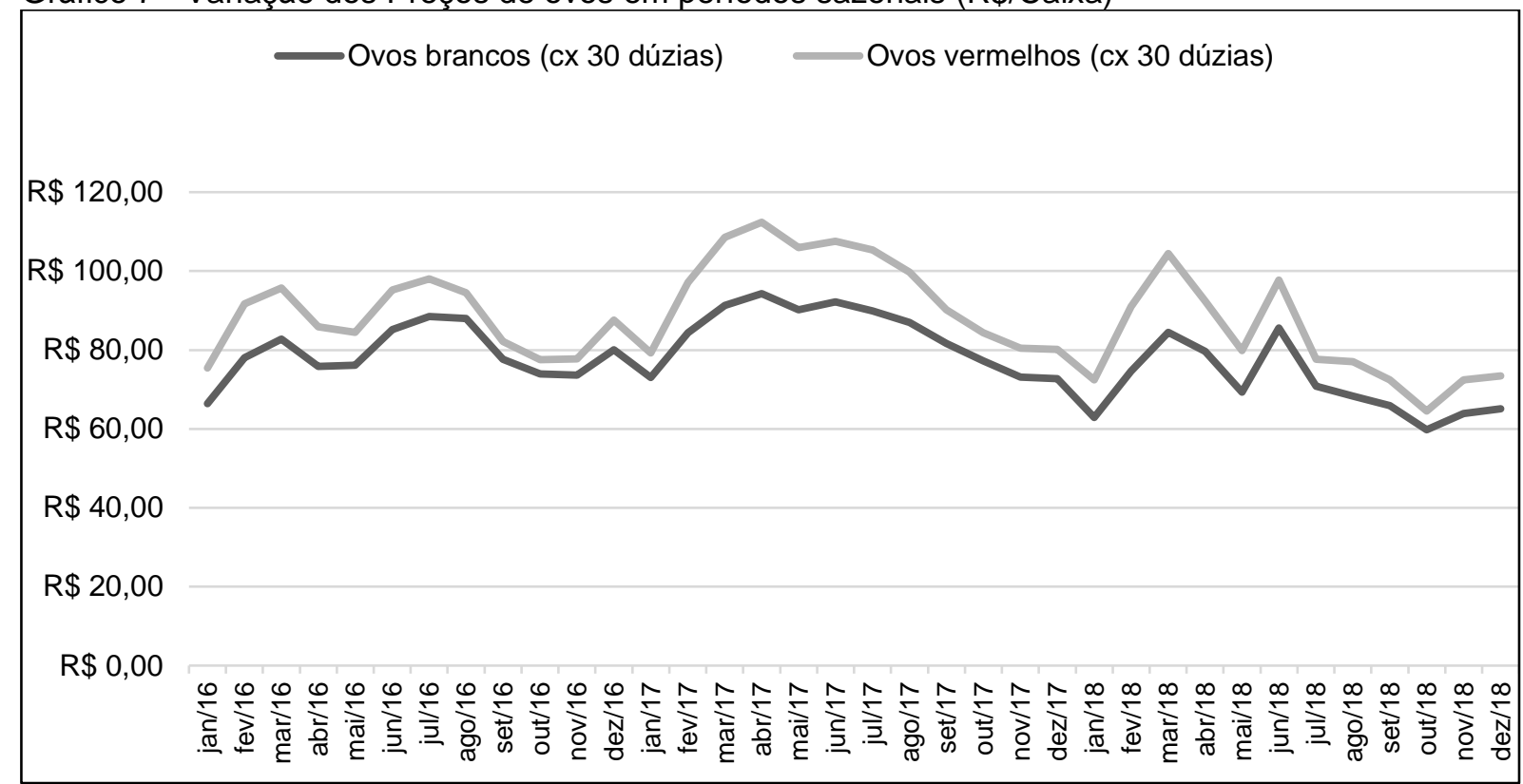

Fonte: CEPEA (2019b).

Os produtores de ovos acreditam que a concorrência permite à empresa se esforçar na modernização e na melhoria contínua de produção. O mercado de ovos se aproxima da concorrência perfeita, por existirem vários produtores e vários compradores. Entretanto, existe confiança e fidelidade entre produtor e comprador, principalmente atacadista, que realizam os negócios com base no relacionamento construído ao longo do tempo (KAKIMOTO, 2011).

\subsection{As pequenas e médias empresas no Brasil}

As pequenas e médias empresas (PMEs) são um grupo de empresas que possuem grande relevância no desenvolvimento do Brasil. Atualmente, as micro e pequenas empresas, que fazem parte desse grupo, representam 98,5\% do total de empresas privadas, contribuem com 27\% do PIB (Produto Interno Bruto) e se responsabilizam por $54 \%$ do total de empregos formais no país (SEBRAE, 2018a).

As PMEs podem ser consideradas parte integrante do ambiente de negócios em qualquer país e são insubstituíveis para a economia local, regional e nacional. Distante das forças de desenvolvimento das grandes empresas, as pequenas e médias empresas são forçadas ao desenvolvimento da inovação para sobreviverem no mercado (BIELIKOVA; MAZANEC, 2016). 
Segundo o IBGE (2003), as principais características desse grupo de empresas são:

- Baixa intensidade de capital;

- Taxas elevadas de natalidade e mortalidade;

- Forte presença do uso da mão-de-obra familiar;

- Poder de decisão centralizado;

- Controle contábil pouco adequado;

- Estreito vínculo da pessoa física dos sócios com a pessoa jurídica na movimentação financeira;

- Utilização de mão-de-obra com baixa qualificação;

- Dificuldade de acesso a financiamento de capital de giro;

- Relação de complementaridade e subordinação com as empresas de grande porte;

- Baixo investimento tecnológico.

Dentro das características acima, a taxa de mortalidade nos primeiros cinco anos de operação se destaca pelo elevado índice de encerramento das atividades no Brasil. Das empresas abertas em 2010, 62,2\% tiveram suas atividades encerradas até 2015, conforme demonstrado no Gráfico 8 (IBGE, 2017a).

Gráfico 8 - Taxa de mortalidade de empresas abertas em 2010 com até 5 anos

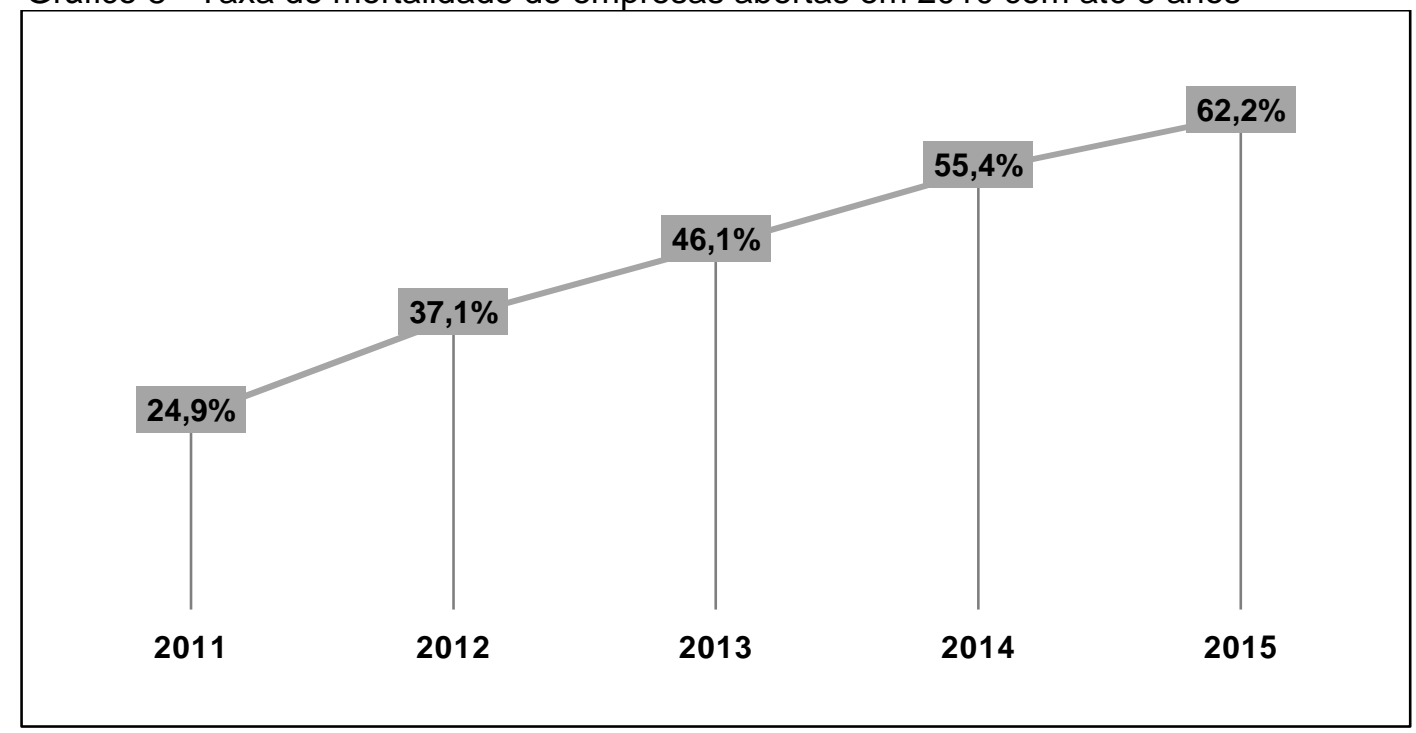

Fonte: IBGE (2017a).

Considerando o período de até dois anos da abertura, as empresas de pequeno porte (EPP) juntamente com as médias empresas (MdE) e grandes empresas (GdE) 
apresentaram menor taxa com relação às microempresas (ME). Segundo o Sebrae (2016a) e o IBGE (2017a), as empresas EPP, MdE e ME tendem a permanecer mais tempo no mercado por terem uma estrutura melhor de capital e de mão de obra.

Gráfico 9 - Taxa de mortalidade por porte de empresas com até 2 anos

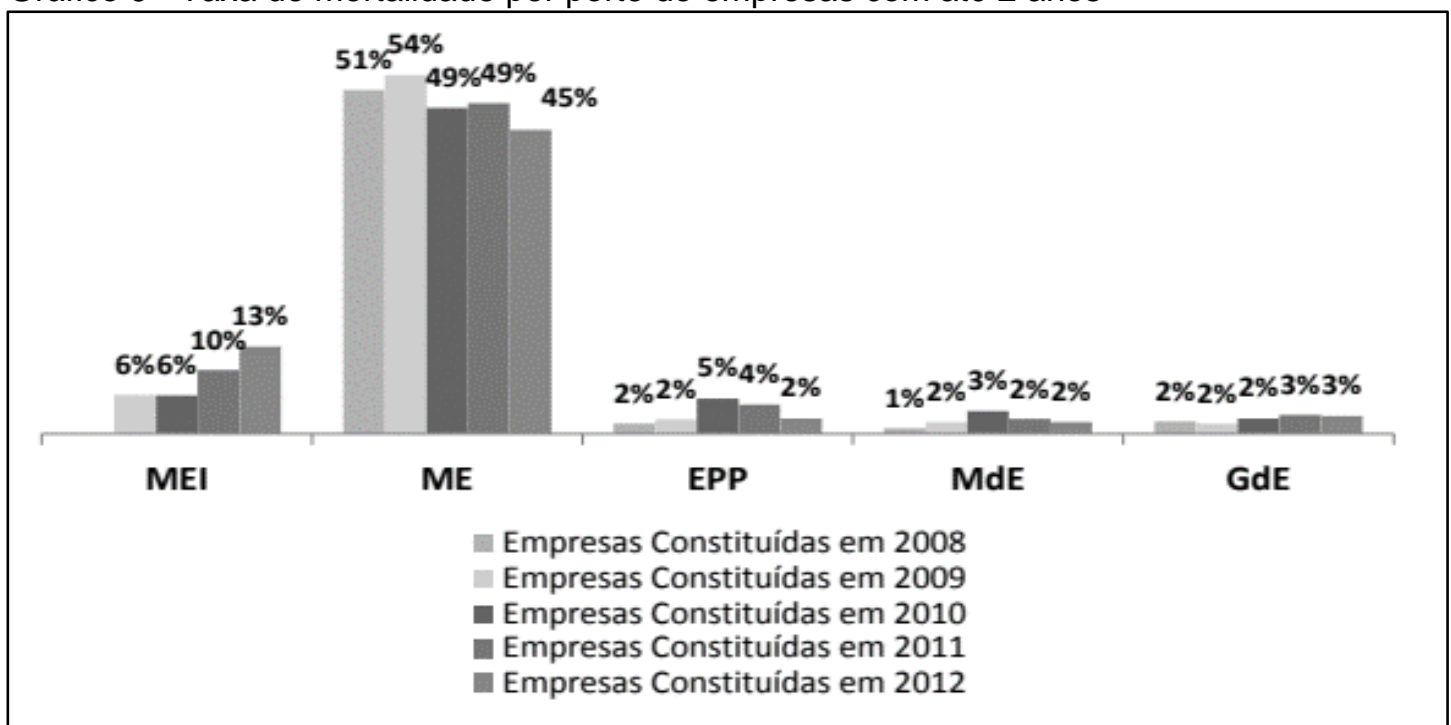

Fonte: Sebrae. Sobrevivência das empresas no Brasil. Brasília, 2016a.

O índice de mortalidade das pequenas e médias empresas no período de 2008 a 2012 reduziu de $45,8 \%$ para 23,4\% para empresas com até dois anos de operação. Ao considerar esse mesmo índice, não contemplando os microempreendedores individuais (MEI), a taxa de mortalidade passa a ser $44,6 \%^{1}$, isto é, a cada 1.000 empresas abertas, 446 empresas tiveram suas atividades encerradas nos dois primeiros anos (SEBRAE, 2016a).

1 Índice calculado com base na taxa de sobrevivência de 55,4\% no período de 2008 a 2012, não contemplando empresas de Microempreendedores Individuais (MEI). 
Gráfico 10 - Taxa de mortalidade de empresas com até 2 anos de operação

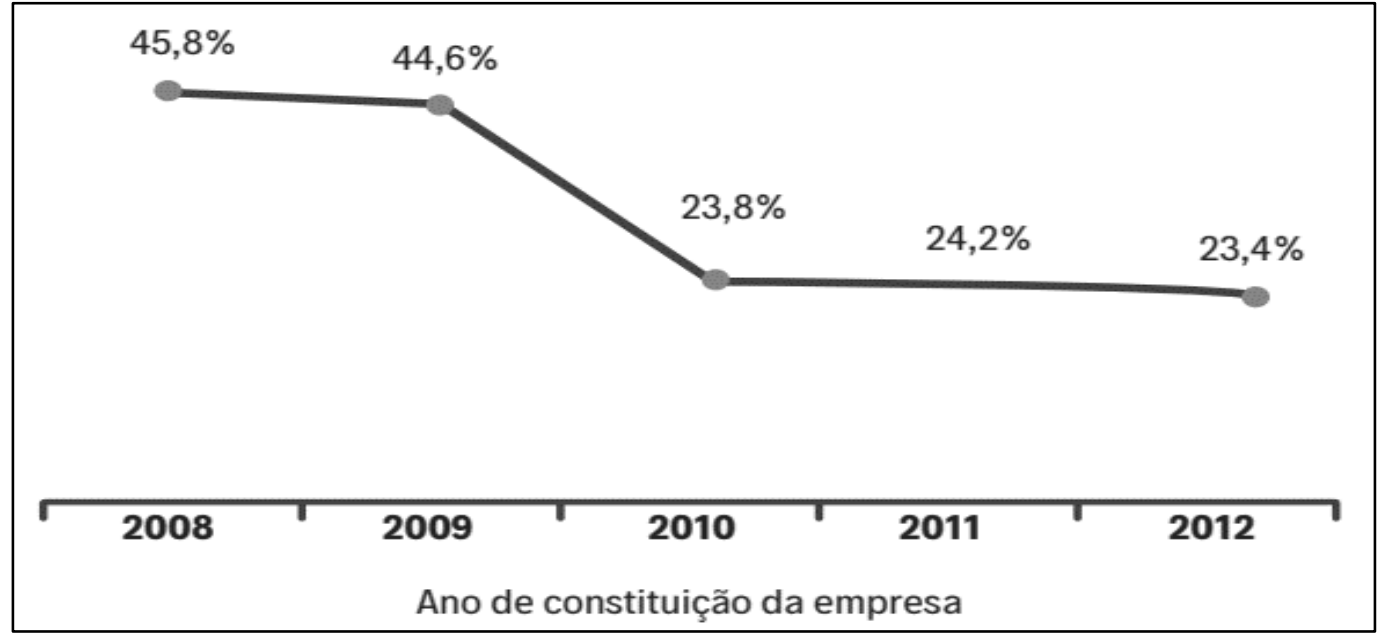

Fonte: Sebrae. Sobrevivência das empresas no Brasil. Brasília, 2016a.

Gráfico 11 - Taxa de sobrevivência de empresas com até 2 anos de operação

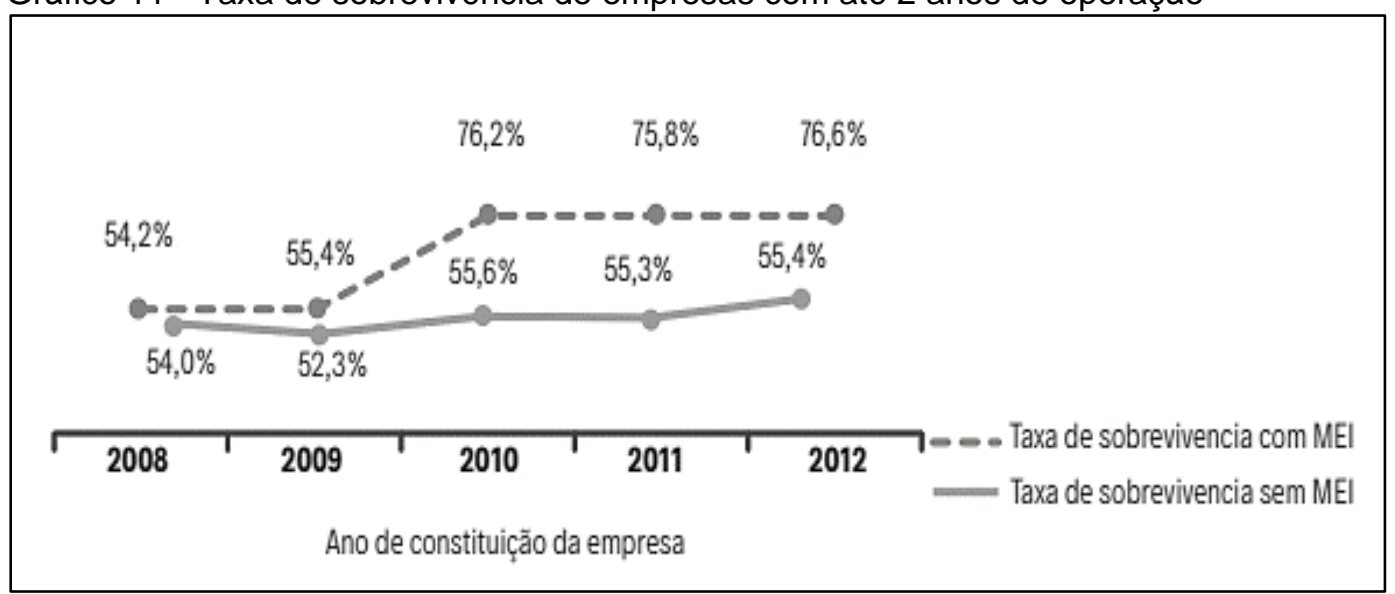

Fonte: Sebrae. Sobrevivência das empresas no Brasil. Brasília, 2016a.

O aumento da taxa de sobrevivência é contribuído por vários fatores positivos que ocorreram na economia nesse período, entre eles a evolução do PIB de 2008 a 2014, que contribui para a redução da taxa de desemprego, aumento do salário mínimo, evolução das taxas de juros, entre outros (SEBRAE, 2016a). 
Gráfico 12 - Evolução do PIB no Brasil no período de 2008 a 2014

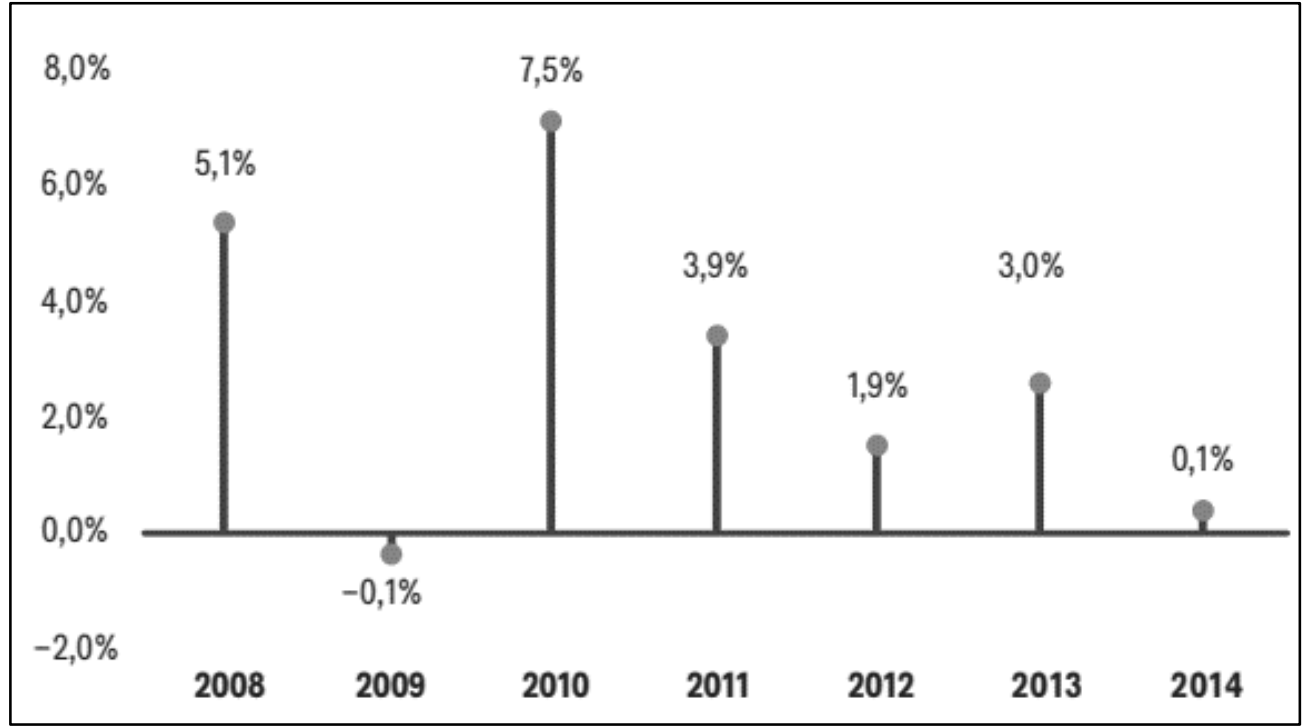

Fonte: Sebrae. Sobrevivência das empresas no Brasil. Brasília, 2016a.

Segundo a pesquisa do Sebrae (2016a), os empreendedores que tiveram suas empresas falidas identificaram como principais causas para que essa situação ocorresse as seguintes razões:

- faltou planejamento ao abrir a empresa;

- faltou acompanhamento das receitas e despesas;

- não conseguiram empréstimo em bancos;

- não conseguiriam negociar com fornecedores suas compras;

- não investiram na capacitação da mão de obra;

- não investiram na capacitação em gestão empresarial enquanto tinham a empresa.

Para Escrivão Filho et al. (2017), o sucesso e o fracasso das pequenas e médias empresas estão fortemente ligados às características individuais do proprietário-gestor, como dedicação integral, disciplina, persistência, disposição para as atividades operacionais e de gestão, assunção do risco, bem como, habilidades para compras, vendas, negociação, finanças e tecnologia da informação e, ainda, atitudes e motivação familiar.

Por conseguinte, a Lei Complementar 123/2006 (BRASIL, 2006a) pode ser considerada um marco para o desenvolvimento das micro e pequenas empresas. Conhecida como a lei que regulou o regime de tributação do Simples Nacional, ela concedeu a essas empresas um tratamento diferenciado, contribuindo para o 
crescimento e consequentemente para a sobrevivência desse nicho perante 0 mercado (SEBRAE, 2018a).

\subsubsection{Critérios de classificação da pequena e média empresa}

À luz de Leone (1991), a definição de uma empresa como pequena e média pode ser dada em diversos critérios, sejam eles quantitativos, qualitativos ou mistos. Para a autora, os critérios quantitativos são de uso recorrente de diversos setores e oferecem informações relacionadas ao nível de faturamento e quantidade de funcionários empregados.

A definição pelo critério qualitativo está relacionada ao perfil e as atitudes dos pequenos e médios empresários em gerir a empresa e, por final, os critérios mistos combinam indicadores econômicos com características sociais e políticas constituídas por critérios quantitativos e qualitativos (LEONE, 1991).

A classificação oficial do porte da empresa como micro e pequena empresa é publicada pela Receita Federal do Brasil por meio da Lei Complementar 123/2006, atualizada pela Lei Complementar 155/2016, no artigo 3o, utilizando como critério de classificação a receita bruta anual:

Art. $3^{\circ}[\ldots]$ consideram-se microempresas ou empresas de pequeno porte, a sociedade empresária, a sociedade simples, a empresa individual de responsabilidade limitada e o empresário a que se refere o art. 966 da Lei no 10.406, de 10 de janeiro de 2002 (Código Civil), devidamente registrados no Registro de Empresas Mercantis ou no Registro Civil de Pessoas Jurídicas, conforme o caso, desde que:

I - no caso da microempresa, aufira, em cada ano-calendário, receita bruta igual ou inferior a $R \$ 360.000,00$ (trezentos e sessenta mil reais); e

II - no caso da empresa de pequeno porte, aufira, em cada ano-calendário, receita bruta superior a $R \$ 360.000,00$ (trezentos e sessenta mil reais) e igual ou inferior a $R \$ 4.800 .000,00$ (quatro milhões e oitocentos e mil reais) [...] (BRASIL, 2006a)

O Banco Nacional do Desenvolvimento (BNDES) e o Banco Central do Brasil (BCB) diferenciam a micro e pequena empresa pela Lei Complementar 123/2006 (BRASIL, 2006a) e a grande empresa pela Lei 11.638/2007 (BRASIL, 2007). Sendo assim, a média empresa é definida entre as faixas de faturamento da pequena empresa e da grande empresa, conforme demonstrado no Quadro 2 abaixo (BCB, 2018; BNDES, 2018). 
Quadro 2 - Critério de classificação de empresa pelo BNDES e BACEN

\begin{tabular}{|l|l|}
\hline \multicolumn{1}{|c|}{ CLASSIFICAÇÃo } & \multicolumn{1}{c|}{ RECEITA OPERACIONAL BRUTA ANUAL } \\
\hline Microempresa & Menor ou igual a $\mathrm{R} \$ 360$ mil \\
\hline Pequena empresa & Maior que $\mathrm{R} \$ 360$ mil e menor ou igual a $\mathrm{R} \$ 4,8$ milhões \\
\hline Média empresa & Maior que $\mathrm{R} \$ 4,8$ milhões e menor ou igual a $\mathrm{R} \$ 300$ milhões \\
\hline Grande empresa & Maior que $\mathrm{R} \$ 300$ milhões ou ativo total superior a $\mathrm{R} \$ 240$ milhões \\
\hline
\end{tabular}

Fonte: adaptado de BCB (2018) e BNDES (2018).

O Sebrae (2013) apresenta como critério de classificação do porte da empresa a quantidade de empregados do IBGE, segmentando a classificação nas atividades da indústria e comércio e serviços, conforme Quadro 3 abaixo:

Quadro 3 - Critério de classificação de empresa pelo Sebrae

\begin{tabular}{|l|c|c|}
\hline \multicolumn{1}{|c|}{ CLASSIFICAÇÃO } & \multicolumn{1}{c|}{ INDÚSTRIA } & COMÉRCIO E SERVIÇO \\
\hline Microempresa & até 19 empregados & até 9 empregados \\
\hline Pequena empresa & de 20 a 99 empregados & de 10 a 49 empregados \\
\hline Média empresa & de 100 a 499 empregados & de 50 a 99 empregados \\
\hline Grande empresa & mais de 500 empregados & mais de 100 empregados \\
\hline
\end{tabular}

Fonte: adaptado de Sebrae (2013).

Portanto, qualquer que seja o critério para definir o tamanho da empresa, este tem de ajudar a classificar a empresa da melhor forma para que os resultados sejam analisados com segurança do ponto de vista econômico, social e político (LEONE, 1991).

\subsubsection{Características que influenciam as PMEs}

As pequenas e médias empresas tem sido ponto de atenção de pesquisadores, pois estes buscam entender os problemas enfrentados por este grupo de empresas. Pesquisadores tem se motivado a direcionar seus estudos a fim 
de orientar os proprietários-gestores dessas empresas a gerirem seus negócios com maior eficiência (LEONE, 1999).

Scott e Bruce (1987) caracterizam os pequenos negócios em três esferas:

1) Gestão: normalmente os gestores são os proprietários/empreendedores;

2) Capital: a empresa pode ser composta por um único proprietário ou um pequeno grupo de pessoas que disponibilizam o capital para empresa funcionar;

3) Abrangência: a área de operações é principalmente local. Trabalhadores e os proprietários estão em uma comunidade doméstica, mas os mercados não precisam ser locais.

Leone (1999) destaca que as características inerentes às pequenas e médias empresas são divididas em três grupos: organizacionais, decisionais e individuais. No grupo de PMEs organizacionais, as seguintes especificidades se destacam:

- Possuem uma gestão mais centralizada e com uma estrutura organizacional simples e de baixo custo que consegue atender às fracas necessidades que apresentam;

- A presença de familiares trabalhando, e a comunicação direta do proprietáriogestor com os funcionários, com um tratamento informal, se destacam nessa estrutura;

- Não possuem controle do ambiente externo e, por isso, dependem de recursos disponíveis;

- A influência das incertezas sobre a estrutura organizacional faz com que o proprietário-gestor não delegue suas atividades, por receio de ocasionar grandes perdas. Por isso, ele prefere agir sozinho e ser guiado mais pela sua sensibilidade do que pelo conhecimento técnico de administração aplicado pelas empresas de maior porte;

- Possuem os processos e controles poucos formalizados e quantificados, bem como dificuldade em planejar atividades e resultados futuros. Nota-se fraca especialização tanto na direção, quanto nos funcionários e na tecnologia;

- O proprietário-gestor conduz a estratégia do negócio com pouca formalização e com base na intuição. A proximidade dele com os funcionários contribui para modificar o planejamento rapidamente; 
- Dificuldade de se antecipar aos problemas devido à ausência de um planejamento formal;

- O estilo de gestão do proprietário-gestor nessas empresas pode ser considerado personalizado;

- Comunicação direta do proprietário-gestor com seus clientes, a fim de entender as expectativas destes com seus produtos.

Com relação ao grupo decisionais, a autora destaca as seguintes especificidades:

- A tomada de decisão é apoiada na experiência, no julgamento ou na intuição do proprietário-gestor com uma visão de curto prazo. Os processos de decisão normalmente são individualistas e diariamente o gestor toma diversas decisões sem qualquer formalização. O proprietário-gestor não possui tempo e habilidade para um olhar analítico e estratégico nas decisões;

- O proprietário-gestor entende seu negócio como sua vida e os objetivos da empresa acabam sendo definidos por seus objetivos pessoais;

- Os dados da empresa nem sempre estão disponíveis para serem analisados e, posteriormente, embasar a tomada de decisões;

Por fim, o grupo de PMEs individuais é caracterizado pelas seguintes especificidades:

- As pequenas e médias empresas são marcadas pela presença predominante de uma única pessoa: o proprietário-gestor. Este tem forte influência no clima organizacional, na estrutura e no desempenho da empresa;

- Quase não há separação entre a pessoa física do proprietário-gestor e a pessoa e a pessoa jurídica da empresa, de maneira que as atividades de uma e de outra afetam-se mutuamente;

- O papel do proprietário-gestor é colocar seu patrimônio à disposição da empresa, colocando em risco seu próprio capital;

- A posição que o proprietário-gestor ocupa na empresa é a origem do seu poder e o reconhecimento do seu status;

- O perfil do pequeno e médio empresário é mais de uma pessoa que corre riscos do que a de um administrador que busca uma gestão com minimização de riscos; 
- O sucesso dessas empresas está associado às competências, atitudes, motivações e ao comportamento organizacional do proprietário-gestor;

- A comunicação direta do proprietário-gestor com seus funcionários permite a ele conhecer e vivenciar os problemas pessoais de seus colaboradores;

- De forma geral, o proprietário-gestor apresenta um comportamento paternalista e, às vezes, egocêntrico.

Para Albuquerque e Escrivão Filho (2007) e Bortoli Neto (1980), o proprietário-gestor da pequena e média empresa tem dificuldade de identificar e diferenciar problemas e sintomas, bem como solucioná-los. Exemplificando, os autores evidenciam que a dificuldade de capital de giro presente nessas empresas é considerada um problema pelos proprietários-gestores e não um sintoma causado pela má administração dos recursos.

Welsh e White (1981) destacam que grande parte das pequenas empresas tendem a crescer com taxas conservadoras, pois possuem dificuldades em pagar por serviços e profissionais especialistas. Assim, o proprietário-gestor necessita ter uma visão generalista sobre o negócio e ser capaz de suportar a mudança de um papel para outro, tolerar a desordem e ater-se às particularidades fundamentais (WELSH; WHITE, 1981).

Bielikova e Mazanec (2016) consideram que, além das dificuldades que as pequenas e médias empresas têm com relação às grandes empresas, elas destacam-se pelas flexibilidades e adaptabilidade em períodos de crescentes pressões competitivas e de crise econômica.

$\mathrm{Na}$ gestão de grandes empresas, os diretores se inclinam a uma sofisticação cada vez maior no modelo de gestão, ao passo que, na pequena empresa, o proprietário-gestor inclina-se aos conhecimentos básicos da administração (WELSH; WHITE, 1981).

A administração das PMEs é marcada em sua maioria pela restrição aos recursos financeiros, a falta de pessoal treinado e uma perspectiva de curto prazo para o gerenciamento. Quando a necessidade é de acesso imediato a financiamento externo, as grandes empresas possuem rápida disponibilidade, o que não corre com as pequenas. A avaliação dos credores para a liberação de um empréstimo é muito pessoal e com base em experiências em outros pequenos tomadores (WELSH; WHITE, 1981). 
Para Welsh e White (1981), uma pequena empresa pode sobreviver sem lucro por um tempo surpreendentemente longo. Para isso, o fluxo de caixa é uma informação mais importante do que a grandeza de valor do lucro ou do retorno sobre o investimento. Para os autores, a liquidez é uma questão de vida ou morte para os pequenos negócios. Portanto, a liquidez da pequena e média empresa deve ser o objetivo primordial do proprietário-gestor e devido à força motriz que elas produzem na economia nacional é necessário apoiá-las tanto financeiramente quanto com consultorias, visando o desenvolvimento futuro (BIELIKOVA; MAZANEC, 2016; WELSH; WHITE, 1981).

\subsubsection{O produtor rural no Brasil - Perfil e caracterização}

O produtor rural pode ser definido como a

pessoa física ou jurídica que explora a terra, com fins econômicos ou de subsistência, por meio da agricultura, da pecuária, da silvicultura, do extrativismo sustentável, da aquicultura, além de atividades não-agrícolas, respeitada a função social da terra (BRASIL, 2006b).

O IBGE (2017b) define o produtor rural como a pessoal jurídica ou física que exerce responsabilidade pelas decisões na utilização de recursos e controle administrativo das operações de exploração das atividades agropecuárias. $O$ produtor rural não necessariamente precisa ser proprietário da terra, pois é possível exercer a produção rural em terras de terceiros, em forma de arredamento.

No primeiro trimestre de 2018 foi apontado, segundo a Pesquisa Nacional por Amostra de Domicílios Contínua, 4,06 milhões de produtores existentes no Brasil, correspondendo aproximadamente a $15 \%$ do número total de empreendedores no país (SEBRAE, 2018c).

Entretanto, de acordo com a série histórica demonstrada no Gráfico 13, 0 número de produtores rurais desde o primeiro trimestre de 2016 vem sofrendo redução. Os motivos para essa redução estão parcialmente associados ao êxodo rural e ao avanço da tecnologia no campo (SEBRAE, 2018c). 
Gráfico 13 - Evolução trimestral do número de produtores rurais

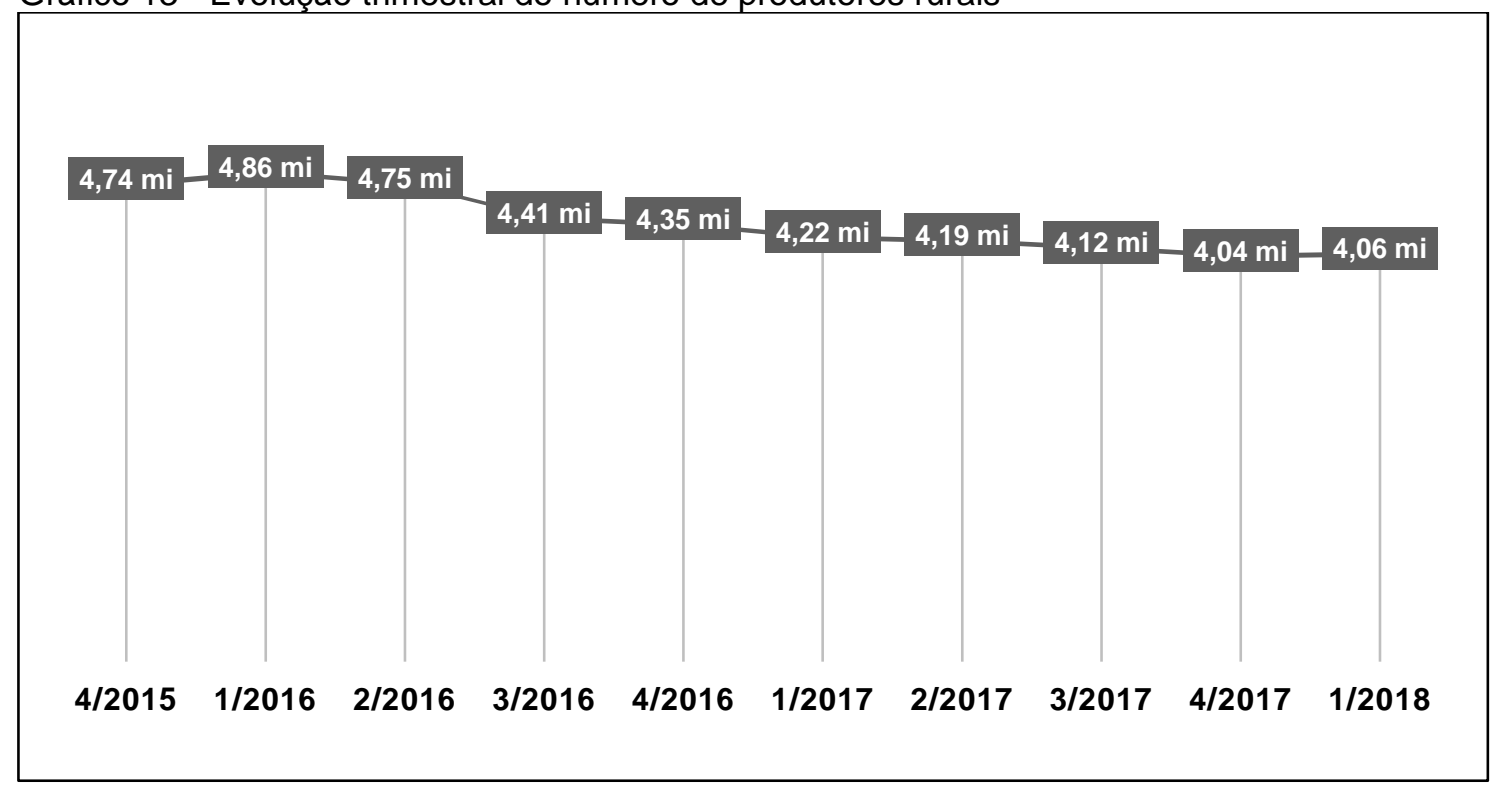

Fonte: adaptado de Sebrae (2018c).

O produtor rural no Brasil apresenta um perfil composto por 81,3\% por homens e 18,7\% por mulheres. A grande maioria dos produtores estão concentrados na faixa etária de 30 a 60 anos e possuem apenas o ensino fundamental, enquanto 23,0\% não sabem ler e escrever (IBGE, 2017b).

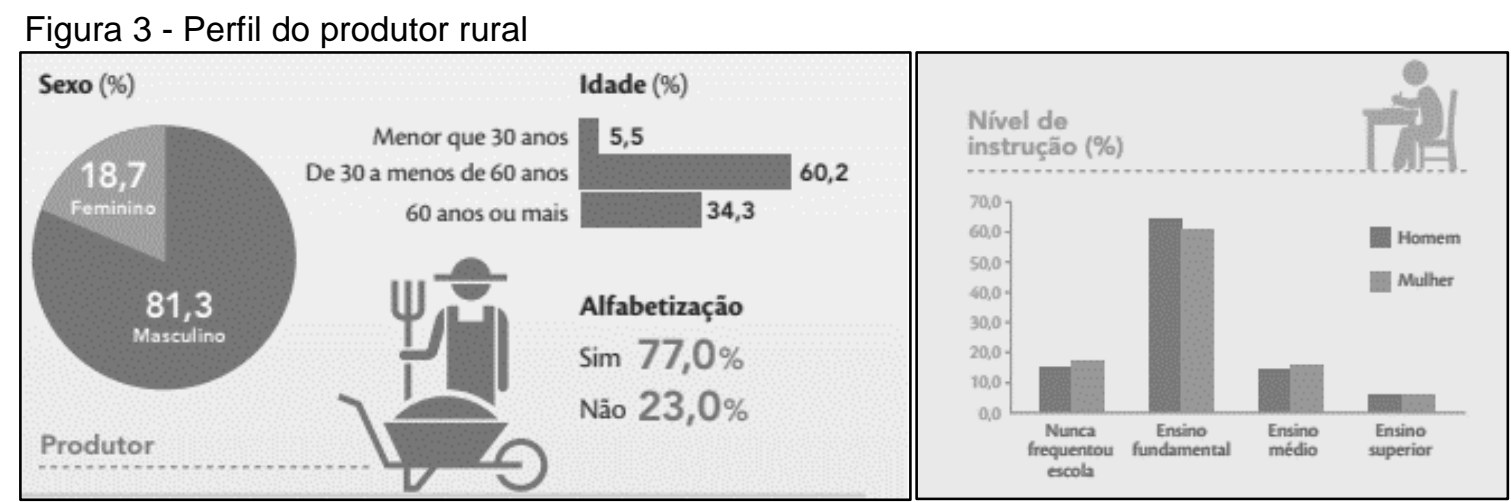

Fonte: IBGE. Censo Agropecuário 2017 (Resultados Preliminares). Rio de Janeiro, 2017b.

Foi demonstrado, ainda, que apenas $20,3 \%$ das propriedades são dirigidas por casais, isto é, a participação do casal na administração da propriedade rural se dá pela divisão total ou parcial das responsabilidades pelo negócio (IBGE, 2017b).

Com relação à finalidade principal da propriedade rural, 60,0\% dos produtores exploram a atividade rural para comercialização da produção, e 40,0\% utilizam a produção rural para consumo próprio e de familiares (IBGE, 2017b).

Os Fundos Constitucionais de Financiamento do Norte (FNO), do Nordeste (FNE) e do Centro-Oeste (FCO) constituídos pela Lei no. 7.827/1989 classificam os 
produtores rurais quanto à renda de acordo com o Quadro 4, incluindo os pequenos e miniprodutores rurais, conforme artigo 3ำ desta lei (SEBRAE, 2012).

Quadro 4 - Critério de classificação de produtora rural segundo a renda

\begin{tabular}{|l|c|}
\hline \multicolumn{1}{|c|}{ CLASSIFICAÇÃO } & RECEITA AGROPECUÁRIA BRUTA \\
\hline Mini/Micro ${ }^{2}$ & até $R \$ 360$ mil \\
\hline Pequeno & acima de $R \$ 360$ mil até $R \$ 3.600$ milhões \\
\hline Pequeno-médio & acima de $R \$ 3.600$ milhões até $R \$ 16.000$ milhões \\
\hline Médio & acima de $R \$ 16.000$ milhões até $R \$ 90.000$ milhões \\
\hline Grande & acima de $R \$ 90.000$ milhões \\
\hline
\end{tabular}

Fonte: adaptado de Sebrae (2012).

Já o Instituto Nacional de Colonização e Reforma Agrária (INCRA) classifica os produtores rurais pelo tamanho das propriedades rurais, de acordo com o Quadro 5 (INCRA, 2018).

Quadro 5 - Critério de classificação de produtor rural segundo tamanho da propriedade

CLASSIFICAÇÃO

Minifúndio

Pequeno

Médio

Grande
TAMANHO

é o imóvel rural com área inferior a 1 (um) módulo fiscal imóvel rural com área compreendida entre 1 (um) e 4 (quatro) módulos fiscais

imóvel rural com área superior a 4 (quatro) até 15 (quinze) módulos fiscais

Fonte: adaptado de INCRA (2018).

Para Nantes (1997), na década de 1980, o produtor rural não se via pressionado a desenvolver seu conhecimento de gestão devido à facilidade de crédito disponível no mercado. Entretanto, o domínio das técnicas de produção nesse período era suficiente para garantir a produtividade e a lucratividade.

Com o transcorrer do tempo, o produtor rural percebeu que não era suficiente apenas o domínio da produção, pois novos desafios da economia, como taxa de juros elevada, inflação crescente nos insumos, sazonalidade, variações bruscas no

\footnotetext{
2 Inclui microempreendedores individuais que tenham auferido receita bruta no ano anterior de até $\mathrm{R} \$$ $60.000,00$.
} 
preço de venda dos produtos produzidos, entre outros fatores, começam a exigir habilidades para tomar decisões financeiras (PROCÓPIO, 1997).

Segundo o IBGE (2017b), apenas 15,5\% dos produtores obtiveram empréstimos ou financiamentos com finalidades de investir, manter e custear sua produção. Dessa parcela, apenas 52,5\% utilizaram-se de recursos provenientes de programas governamentais. Muito embora a grande maioria não goste de assumir riscos, os produtores rurais financiam a maior parte da safra com capital próprio (FIESP, 2018).

Gráfico 14 - Finalidades do empenho de empréstimos/financiamentos obtidos

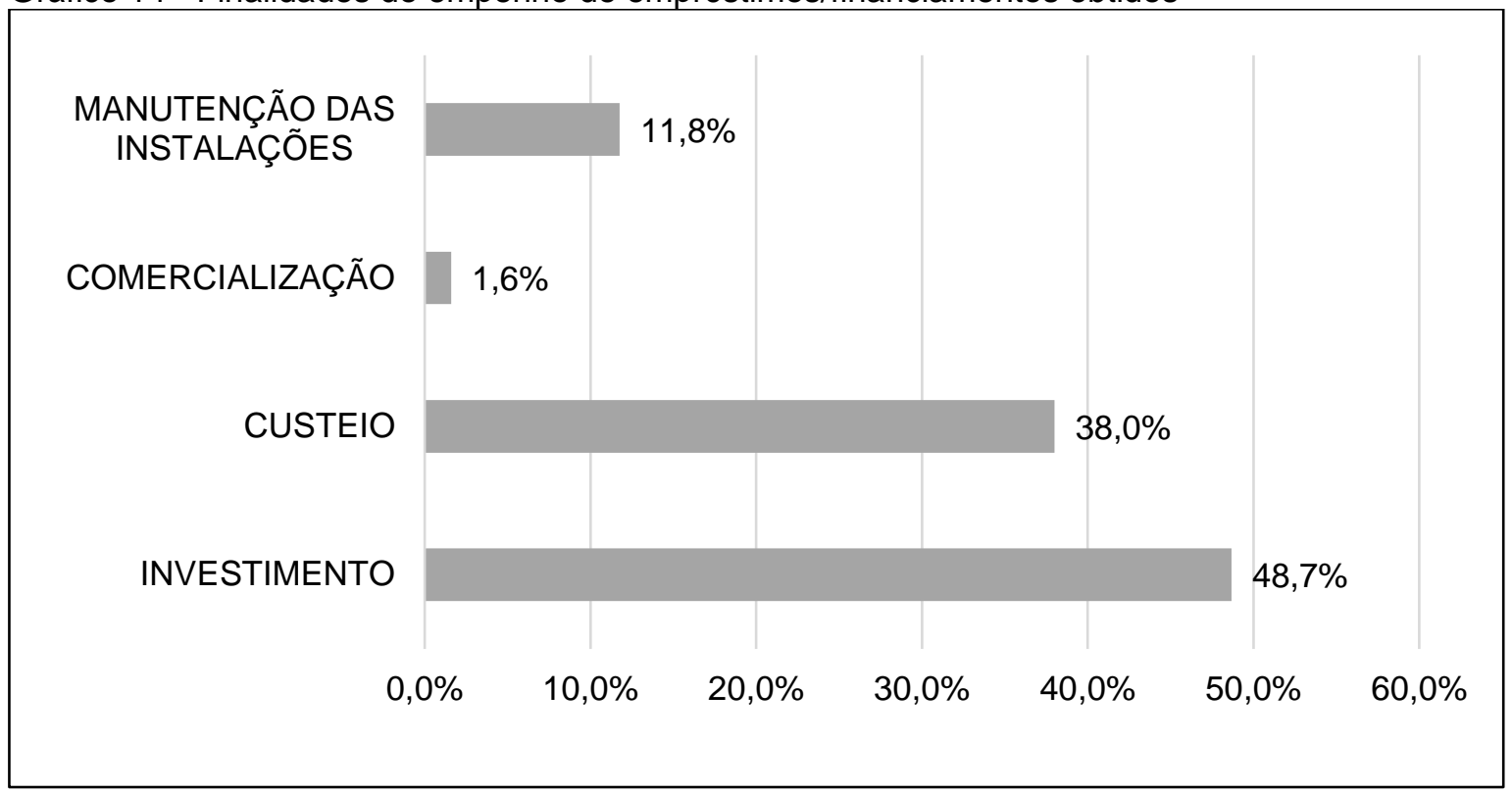

Fonte: adaptado de IBGE/SIDRA (2017b). 
Gráfico 15 - Proporção de recursos tomados com e sem subsídios do governo

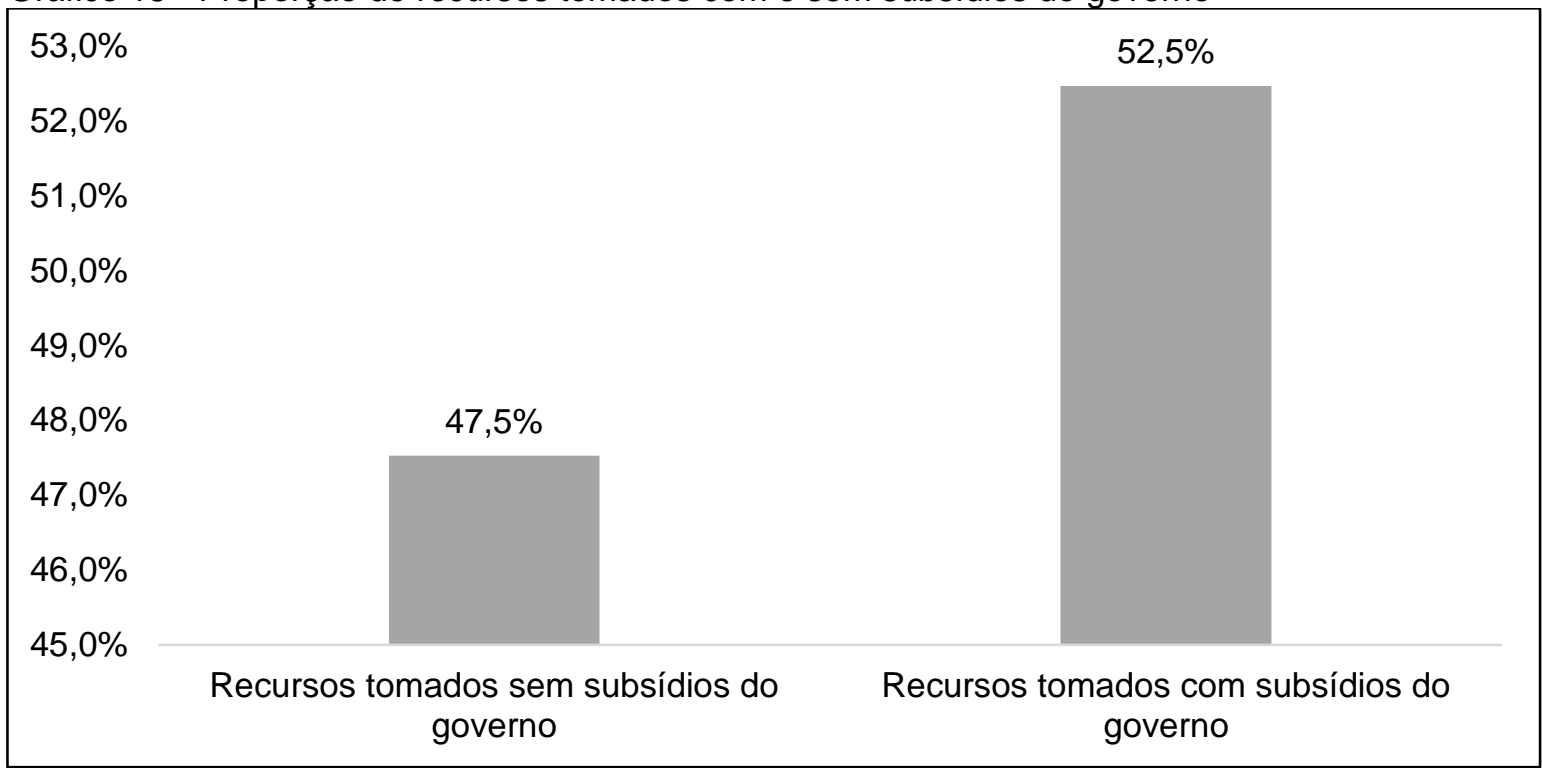

Fonte: adaptado de IBGE/SIDRA (2017b).

Já $41,8 \%$ dos produtores desenvolvem atividades nas propriedades como principal fonte de renda, isto é, o produtor depende da produção agrícola para sua sobrevivência, enquanto $58,2 \%$ dos produtores não dependem das atividades agrícolas (IBGE, 2017b).

Por isso, a busca pela profissionalização diante dos desafios fez com que o produtor rural implementasse tecnologias modernas para melhorar sua produção, planejamento e controle, a fim de obter eficiência na rentabilidade da propriedade (MARION; SEGATTI, 2005).

Os desafios do produtor rural são vários, tanto na gestão quanto nas técnicas do campo, mas a preponderância dos fatores do campo ligados às condições biológicas das culturas e criações, associadas a pragas, doenças, clima, entre outros exigem que o produtor se planeje antecipadamente prevendo os riscos que podem comprometer seu negócio financeiramente (MARION; SEGATTI, 2005).

Portanto, é muito importante que o produtor rural trate sua propriedade como uma empresa com visão de longo prazo, com boas práticas de gestão e não apenas como uma extensão de um bem familiar. Assim, é necessário aplicar ferramentas de controle que permitam a obtenção das informações de forma simples e prática para a tomada de decisão (SILVA, 2017).

\subsection{Visão básica da administração financeira}


Administrar uma empresa, seja ela pequena, média ou grande, envolve muitas funções diferentes. Independentemente do tamanho, o gestor financeiro dever ter uma visão ampliada do negócio e controle das principais áreas, como gestão de marketing, finanças, recursos humanos, produção, estoques, compras, logística e pesquisa e desenvolvimento (GITMAN,1997).

Finanças é a área que se intersecciona com todas as demais e direciona os recursos necessários para que estas outras mantenham-se em funcionamento. Sem recursos para atender aos investimentos necessários para o crescimento ou para atender às operações do dia a dia, a área financeira pode limitar o desenvolvimento de novos produtos, novas campanhas de marketing, aumento de produção, capacitação da mão de obra, redução de custos e outras importantes decisões estratégicas (GITMAN, 1997).

Sendo assim, o papel do gestor financeiro é de grande importância para a empresa, para assegurar que os recursos estejam disponíveis dentro do tempo planejado, no montante planejado e ao menor custo. Caso contrário, a empresa estará destinada à falência (GITMAN,1997).

No Brasil, pequenos e médios empreendedores que desempenham papel de gestores financeiros, cujas empresas fecharam, relataram que os problemas financeiros, tais como falta de capital de giro, linha de crédito, inadimplência e custos foram alguns dos principais motivos para que a empresa deixasse de funcionar (SEBRAE, 2016b).

Para esse caso, Ross, Westerfield e Jordan (1998) afirmam que o gestor deve se preocupar com três visões básicas para garantir a disponibilidade de recursos, 0 crescimento da empresa e a continuidade do negócio. Ao analisar detalhadamente cada uma dessas visões, os teóricos as diferenciam como:

- Investimentos: trata-se da capacidade do gestor financeiro de identificar as oportunidades de ativos que geram valor superior a seu custo de aquisição, isto é, o fluxo de caixa gerado por um novo investimento deve superar o custo desse investimento. Para isso, é importante haver um planejamento de investimento que contemple o montante a ser investido, o prazo do investimento e os riscos que podem surgir e comprometer a decisão do investimento.

- Financiamentos: está relacionado à forma pela qual a empresa obtém recursos para sustentar seus investimentos dentro do prazo estabelecido. 
Nesse ponto, o gestor financeiro deve se atentar em saber qual o montante necessário que a empresa precisa obter emprestado e quais são as fontes disponíveis que apresentam o menor custo.

- Capital de giro: está relacionada à gestão dos ativos de curto prazo que a empresa possui, como, por exemplo, estoques, clientes a receber, dinheiro disponível nas contas bancárias, bem como as obrigações de curto prazo, tais como, folha de pagamento, fornecedores, impostos e outros. A gestão do capital de giro está totalmente concatenada na atividade principal da empresa. O capital de giro demanda uma rotina diária que o administrador financeiro necessita controlar com precisão, para assegurar que a empresa tenha recursos suficientes a curto prazo e evitar dificuldades financeiras ou interrupção na operação.

Para gerir os recursos financeiros de uma empresa, o gestor financeiro necessita entender as informações divulgadas nas três principais demonstrações financeiras: o Balanço Patrimonial (BP), a Demonstração de Resultados do Exercício (DRE) e a Demonstração de Fluxos de Caixa (DFC) (ROSS; WESTERFIELD; JAFFE, 2002).

Na ótica da Comissão de Valores Mobiliários - CVM (1986), órgão regulador do mercado de capitais no país, o objetivo principal das demonstrações contábeis é permitir que os usuários avaliem a situação econômica, financeira da empresa e a evolução patrimonial.

Ainda assim, o Financial Accounting Standards Board - FASB (1987), órgão regulador das normas contábeis nos EUA, afirma que as informações contábeis relevantes são capazes de fazer a diferença em uma decisão, ajudando os usuários a formar previsões sobre os resultados de eventos passados, presentes e futuros ou para confirmar ou corrigir expectativas anteriores.

Entretanto, uma pesquisa realizada por Maingot e Zeghal (2006) indica que os gestores nas pequenas e médias empresas utilizam os demonstrativos financeiros apenas para fins de tributação e captação de empréstimos, e um dos principais motivos para tal é a complexidade em entender as informações publicadas.

Portanto, para um entendimento básico, a seguir serão abordados conceitos e estruturas das três principais demonstrações financeiras: o Balanço Patrimonial, a Demonstração de Resultados do Exercício e a Demonstração dos Fluxos de Caixa. 


\subsubsection{O Balanço Patrimonial}

Ross, Westerfield, Jaffe (2002) e Gitman (1997), definem que o Balanço Patrimonial é uma demonstração financeira que evidencia a posição dos bens, direitos e obrigações da empresa em um dado momento, por isso possui a característica de uma demonstração estática.

O Balanço Patrimonial, assim como as demais demonstrações, segue normas contábeis e leis regulamentadoras de suas estruturas e publicações em consonância com os padrões internacionais (BRASIL, 2007).

Segundo o Comitê de Pronunciamentos Contábeis (CPC, 2009), o Balanço Patrimonial para pequenas e médias empresas é estruturado pelos seguintes grupos:

- Ativo: composto pelos bens e direitos da empresa, representa o resultado de eventos passados com a expectativa de gerar benefícios econômicos futuros para a empresa. Nesse grupo é possível identificar os saldos de estoques de matéria-prima e produto acabado, caixa e equivalentes de caixa, clientes a receber, investimentos (participação em outras empresas e direitos que não fazem parte da atividade-fim da empresa), imobilizados (máquinas, equipamentos, veículos e outros), intangível (marcas, patentes), entre outras contas.

- Passivo: composto por obrigações geradas em eventos já ocorridos pela empresa, cuja liquidação se resulta na saída de recursos econômicos. Nesse grupo, é possível identificar os saldos de fornecedores a pagar, impostos a recolher, financiamentos, direitos trabalhistas e outras contas.

- Patrimônio líquido: é o residual da diferença entre ativo e passivo. Nesse grupo, é possível identificar os montantes de capital integralizado pelos sócios, lucros ou prejuízos acumulados, reserva de lucros, entre outras contas.

$\mathrm{Na}$ estrutura do Balanço Patrimonial é possível identificar uma importante diferenciação nos grupos de Ativo e Passivo, mediante a classificação em circulante e não circulante. Essa classificação diferencia os registros financeiros em curto e longo prazo (CPC, 2011).

As contas classificadas em ativos circulantes e passivos circulantes possuem vencimentos de curto prazo, isto é, contas que serão liquidadas em até doze meses. 
Acima desse prazo, as contas serão classificadas como ativos e passivos não circulantes, conforme modelo demonstrado no Quadro 6 (CPC, 2011).

Quadro 6 - Modelo de Balanço Patrimonial

\begin{tabular}{|c|c|c|c|c|c|}
\hline \multicolumn{6}{|c|}{$\begin{array}{c}\text { COMPANHIA XYZ LTDA } \\
\text { Balanço Patrimonial } \\
\text { ncerrado em xx de xx de 20x8 (em milhares de \$) }\end{array}$} \\
\hline ATIVO & $20 \times 8$ & $20 \times 7$ & PASSIVO & $20 \times 8$ & $20 \times 7$ \\
\hline ATIVO CIRCULANTE & & & PASSIVO CIRCULANTE & & \\
\hline $\begin{array}{l}\text { Caixa e equivalentes de } \\
\text { caixa }\end{array}$ & 400 & 380 & Fornecedores & 400 & 380 \\
\hline Clientes & 600 & 570 & Impostos a pagar & 250 & 238 \\
\hline \multirow[t]{2}{*}{ Estoques } & 600 & 570 & Contas a pagar & 100 & 95 \\
\hline & & & Salários a pagar & 200 & 190 \\
\hline ATIVO NÃO CIRCULANTE & & & PASSIVO NÃO CIRCULANTE & & \\
\hline Realizável a longo prazo & 300 & 285 & Financiamentos a longo prazo & 500 & 475 \\
\hline Investimentos & 300 & 285 & & & \\
\hline Imobilizados & 200 & 190 & PATRIMÔNIO LÍQUIDO & & \\
\hline Intangível & 100 & 95 & Capital Social & 500 & 500 \\
\hline \multirow[t]{2}{*}{$\begin{array}{l}\text { ( - ) Depreciação } \\
\text { acumulada }\end{array}$} & (150) & (143) & Reservas de Capital & 100 & 150 \\
\hline & & & Reservas de Lucros & 300 & 205 \\
\hline TOTAL & 2.350 & 2.233 & TOTAL & 2.350 & 2.233 \\
\hline
\end{tabular}

Fonte: Própria autoria.

Portanto, por meio da análise do Balanço Patrimonial, é possível extrair indicadores de liquidez que demonstram a capacidade financeira que a empresa possui para honrar seus compromissos em curto e longo prazo, taxas de retorno sobre o capital investido pelos sócios/acionistas, bem como o retorno sobre ativos investidos pela empresa para a geração de receitas, grau do endividamento, evolução patrimonial da empresa, entre outros (ROSS; WESTERFIELD; JORDAN, 1998). 


\subsubsection{A Demonstração de Resultados do Exercício}

A Demonstração de Resultados do Exercício (DRE) é um relatório financeiro dinâmico que fornece um resumo das operações da empresa durante um determinado período, confrontando as receitas com os custos e despesas para se obter o resultado econômico (GITMAN, 1997).

Os gestores financeiros tratam o demonstrativo como uma importante base de informação para uma análise econômica. Através do resultado da última linha da demonstração é possível verificar se o resultado foi positivo ou negativo, significando assim lucro ou prejuízo (GUILDING; PIZAM, 2010).

$\mathrm{Na} \mathrm{DRE}$, os registros contábeis são realizados pelo regime de competência, isto é, as receitas e despesas são reconhecidas quando ocorre o fato gerador e não apenas no momento do pagamento ou recebimento ${ }^{3}$ (ROSS; WESTERFIELD; JORDAN, 1998).

É muito importante que o gestor financeiro saiba diferenciar os regimes de competência e de caixa, pois a DRE pode apresentar despesas que não tenham transitado no fluxo de caixa e resultar numa análise equivocada realizada pelo gestor em relação ao resultado da empresa (ROSS; WESTERFIELD; JORDAN, 1998).

Despesas com depreciação, amortização e exaustão que estão adicionadas no resultado são exemplos de despesas não desembolsáveis. Esse tipo de despesa está relacionado ao valor de recomposição de um ativo pela sua utilização e desgaste ao longo do tempo (DAS, 2017).

Entretanto, essas despesas não afetam o fluxo de caixa, pois são apenas para informação contábil. $O$ registro da depreciação e de outras despesas não desembolsáveis na DRE permitem que a empresa recolha menos impostos, devido à redução do lucro tributável (GITMAN, 1997).

A disposição das contas no demonstrativo segue uma ordem padrão. A primeira conta a ser apresentada na demonstração é a das receitas relacionadas à atividade principal da empresa, seguida dos impostos e abatimentos sob as vendas,

\footnotetext{
${ }^{3} \mathrm{O}$ reconhecimento de receitas e despesas no momento do recebimento ou pagamento é caracterizado como regime de caixa, sendo assim é utilizado apenas no fluxo de caixa.
} 
custos de produção da mercadoria e despesas operacionais (ROSS; WESTERFIELD; JORDAN, 1998).

Esse grupo de contas está relacionado à atividade principal da empresa e por isso elas são posicionadas logo no início da demonstração. As demais contas, tais como, receitas financeiras, despesas financeiras e impostos sob resultado são posicionadas logo após o primeiro grupo, conforme modelo demonstrado no Quadro 7 (ROSS; WESTERFIELD; JAFFE, 2002).

Quadro 7 - Modelo Demonstração de Resultados do Exercício

\begin{tabular}{|c|c|}
\hline $\begin{array}{c}\text { COMPANHIA XYZ LTDA } \\
\text { Demonstração de Resultados do Exercício } \\
\text { (em milhares de \$) }\end{array}$ & \\
\hline $\begin{array}{l}\text { RECEITA OPERACIONAL BRUTA } \\
\text { ( - ) Deduções das Vendas }\end{array}$ & $\begin{array}{l}20 \times 8 \\
100.000\end{array}$ \\
\hline Impostos sobre vendas & 20.000 \\
\hline Devoluções & 10.000 \\
\hline Abatimentos & 2.000 \\
\hline RECEITA OPERACIONAL LÍQUIDA & 68.000 \\
\hline ( - ) Custo das Mercadorias, Produtos e Serviços Prestados & 25.000 \\
\hline $\begin{array}{l}\text { LUCRO OPERACIONAL BRUTO } \\
\text { ( - ) Despesas Operacionais }\end{array}$ & 43.000 \\
\hline Administrativas & 5.000 \\
\hline Comerciais & 2.000 \\
\hline Outras despesas e receitas operacionais & 1.000 \\
\hline RESULTADO ANTES DAS RECEITAS E DESPESAS FINANCEIRAS & 35.000 \\
\hline ( +/- ) Despesas e Receitas Financeiras & 3.000 \\
\hline RESULTADO ANTES DOS TRIBUTOS SOBRE O LUCRO & 38.000 \\
\hline ( - ) Provisão Impostos sob resultados & 12.920 \\
\hline LUCRO LÍQUIDO OU PREJUÍZO DO EXERCÍCIO & 25.080 \\
\hline
\end{tabular}

Fonte: Própria autoria.

Nota-se que o lucro é demonstrado em dois níveis: primeiro como lucro bruto, que é calculado pela dedução da receita liquida menos os custos dos produtos e 
segundo como lucro líquido, quando deduzido todas as despesas e os impostos sob resultados (GUILDING; PIZAM, 2010).

Essa diferenciação permite ao administrador monitorar a eficiência da empresa. O lucro bruto pode ser considerado um indicador de rentabilidade quando comparado com a receita. Quanto maior a margem de lucro bruto melhor será o retorno sobre as vendas, pois a empresa está retendo mais retorno para cada unidade monetária de vendas. Se o lucro bruto diminuir ao longo do tempo, o gestor consegue perceber o movimento dinâmico entre um período e outro e agir rapidamente (AUSTRALIA, 2018).

O mesmo ocorre com o lucro líquido, que demonstra o quanto a empresa está obtendo de margem liquida sobre a receita após pagar todas as despesas. Esses e outros indicadores são muito importantes para demonstrar ao gestor quais pequenos ajustes de um período para o outro podem tornar o negócio mais lucrativo (AUSTRALIA, 2018).

\subsubsection{A Demonstração dos Fluxos de Caixa}

O demonstrativo de fluxo de caixa era preparado há muito tempo pelos comerciantes da antiguidade e era chamado de "declarações de fundos". Em meados de 1800, nessas declarações eram registradas apenas as receitas e despesas que efetivamente eram recebidas e pagas. Em meados de 1920, a definição de "fundos" passou a ser chamada de capital de giro (CHEATHAM; CHEATHAM, 1993).

Em 1986, a organização americana FASB emitiu a declaração FAS95, que passou a vigorar no ano seguinte, normatizando a Demonstração de Fluxos de Caixa (DFC) em todo território norte-americano e seguindo como modelo para os demais países e outras organizações de normas contábeis (CHEATHAM; CHEATHAM, 1993).

No Brasil, o Comitê de Pronunciamentos Contábeis emitiu em julho de 2008 o pronunciamento CPC 03, regulamentando o Demonstrativo de Fluxo de Caixa no

Brasil no modelo emitido pelo FASB juntamente com o International Accounting Standards Board (IASB) (CPC, 2008). 
Entretanto, a Lei 11.638/07 no seu artigo 176, parágrafo 6º prevê que apenas as companhias fechadas ${ }^{4}$ com patrimônio líquido inferior a $R \$ 2.000 .000,00$ (dois milhões de reais) não serão obrigadas à elaboração e publicação da DFC (BRASIL, 2007).

Independentemente da exigência à elaboração e publicação para atendimento da legislação, a DFC tem sido considerada por alguns pesquisadores como a demonstração financeira mais importante para a gestão de uma empresa devido à relevância das informações no processo decisório (SILVA; SANTOS; OGAWA, 1993).

O grande obstáculo para os gestores de pequenas e médias empresas é entender como resolver seus problemas financeiros apenas com o gerenciamento do Balanço Patrimonial e da Demonstração de Resultados do Exercício. Esses demonstrativos acabam sendo incapazes de interseccionar os números publicados com os problemas de fluxo de caixa (CHEATHAM; CHEATHAM, 1993).

O objetivo principal da DFC é prover informações relevantes de todos os recebimentos e pagamentos da empresa, bem como o resultado do fluxo financeiro presente e futuro, permitindo ao gestor antecipar suas necessidades de dinheiro ou escolher a melhor forma de aplicação do excedente (FRANCISCO et al., 2001).

De acordo com a definição do FASB (1987), o objetivo principal da demonstração de fluxos de caixa é avaliar a liquidez, solvência, viabilidade e a flexibilidade financeira da empresa.

Segundo Boer (1999), o Demonstrativo de Fluxos de Caixa demonstra de que forma o dinheiro entrou e saiu da empresa, identificando as fontes e aplicações de caixa. Essas movimentações registradas são utilizadas pelos seus usuários, segundo o FASB (1987) para:

a) avaliar a capacidade da empresa em gerar fluxos de caixa futuros positivos;

b) avaliar a capacidade da empresa em cumprir suas obrigações, sua capacidade de remunerar os sócios pelo capital investido e suas necessidades de financiamento;

\footnotetext{
${ }^{4}$ Companhias fechadas são empresas não listadas em bolsa de valores.
} 
c) avaliar as razões das diferenças entre o lucro líquido obtido pela DRE e os recebimentos de caixa associados aos pagamentos;

d) avaliar os efeitos sobre a posição financeira da empresa tanto do caixa operacional quanto de investimentos e financiamento durante o período.

Ainda sobre a norma FAS95, o Demonstrativo de Fluxos de Caixa permite ao gestor ter três visões estratégicas do negócio: o fluxo de caixa da atividade operacional, de investimento e de financiamento (FASB,1987).

O fluxo de caixa da atividade operacional está relacionado com as movimentações de receitas e despesas que envolvem a atividade principal da empresa. O montante gerado nesse fluxo de caixa é um indicador chave para manter a capacidade operacional da empresa, amortizar empréstimos, remunerar os sócios e realizar novos investimentos sem recorrer a capital de terceiros. Exemplos de receitas e despesas decorrentes da operação, segundo o pronunciamento CPC 03 (2010), são:
a) recebimento das vendas de mercadorias e prestação de serviços;
b) pagamento de fornecedores de mercadorias e serviços;
c) pagamento de salários, encargos e benefícios;
d) pagamentos dos impostos sob receita e resultado;

A segunda visão estratégica é o fluxo de caixa da atividade de investimento. Essa atividade está relacionada aos empenhos de recursos que a empresa necessita para gerar lucros e fluxo de caixa futuro. São exemplos de entradas e saídas do fluxo de investimentos, segundo o pronunciamento CPC 03 (2010):

a) recebimento pela venda de ativo imobilizado, intangíveis e outros ativos de longo prazo;

b) pagamento pela aquisição de imobilizados;

c) pagamento pela aquisição de ações de outras empresas e de novos negócios;

d) empréstimo a terceiros.

Como última visão estratégica, o fluxo de caixa da atividade de financiamento, de acordo com os parágrafos 18 ao 20 da norma FAS95, inclui a obtenção de dinheiro dos sócios, bem como a devolução do dinheiro emprestado ou a remuneração do capital investido e, ainda, obtenção e pagamento por outros recursos a credores por crédito de longo prazo. São exemplos de entradas e saídas do fluxo de financiamento (FASB,1987): 
a) entrada de caixa por emissão de ações e outros instrumentos patrimoniais;

b) entrada de caixa de empréstimos de curto e longo prazo;

c) pagamento de empréstimos e financiamentos de curto e longo prazo;

d) pagamento de dividendos e outras distribuições aos sócios.

Segundo os pronunciamentos CPC 03 (2010) e FASB (1987), o Demonstrativo de Fluxos de Caixa pode ser apresentado por dois métodos alternativos: direto e indireto.

O método direto demonstra o fluxo de caixa líquido das atividades operacionais a partir da diferença dos recebimentos de caixa bruto e pagamentos a fornecedores, empregados, governo entre outros, conforme modelo demonstrado no Quadro 8 (FASB,1987).

Quadro 8 - Modelo Demonstração de Fluxos de Caixa - Método Direto

\begin{tabular}{|c|c|c|c|}
\hline \multicolumn{4}{|c|}{$\begin{array}{c}\text { COMPANHIA XYV LTDA. } \\
\text { DEMONSTRAÇÃO DE FLUXOS DE CAIXA } \\
\text { (em milhares \$) }\end{array}$} \\
\hline & $20 \times 1$ & $20 \times 2$ & $20 \times 3$ \\
\hline RECEITAS OPERACIONAIS & 3.000 & 4.500 & 8.000 \\
\hline Receita com vendas & 1.000 & 3.000 & 5.000 \\
\hline Receita com prestação de serviços & 2.000 & 1.500 & 3.000 \\
\hline DESPESAS OPERACIONAIS & 297 & 465 & 582 \\
\hline Fornecedores de mercadorias & 100 & 250 & 400 \\
\hline Despesas de expediente & 24 & 50 & 30 \\
\hline Serviço de terceiros & 18 & 5 & 12 \\
\hline Folha de pagamento & 100 & 130 & 130 \\
\hline Outras despesas operacionais & 55 & 30 & 10 \\
\hline SALDO DO FLUXO DE CAIXA OPERACIONAL (1) & 2.703 & 4.035 & 7.418 \\
\hline Venda de ativos & - & - & - \\
\hline Aquisição de ativos e investimentos & 3.000 & 1.400 & 300 \\
\hline SALDO DO FLUXO DE CAIXA DE INVESTIMENTO (2) & $(3.000)$ & $(1.400)$ & $(300)$ \\
\hline Entrada de empréstimos & - & - & - \\
\hline Amortização de empréstimos & 3.000 & 3.000 & 3.000 \\
\hline SALDO DO FLUXO DE CAIXA DE FINANCIAMENTO (3) & $(3.000)$ & $(3.000)$ & $(3.000)$ \\
\hline GERAÇÃO DE CAIXA NO PERÍODO $(1+2+3)$ & $(3.297)$ & $(365)$ & 4.118 \\
\hline Saldo inicial das disponibilidades & 10.000 & 6.703 & 6.338 \\
\hline Saldo final das disponibilidades & 6.703 & 6.338 & 10.456 \\
\hline
\end{tabular}

Fonte: Própria autoria. 
O método indireto obtém o fluxo de caixa líquido operacional a partir do lucro líquido ou prejuízo apurado pela DRE, ajustando o resultado com itens de receitas e despesas que não são operacionais e que não transitam pelo caixa, bem como a variação de contas do Balanço Patrimonial, conforme o modelo do Quadro 9 (FASB,1987).

Quadro 9 - Modelo Demonstração de Fluxos de Caixa - Método Indireto

\begin{tabular}{|c|c|c|c|}
\hline \multicolumn{4}{|c|}{$\begin{array}{c}\text { COMPANHIA XYV LTDA. } \\
\text { DEMONSTRAÇÃO DE FLUXOS DE CAIXA } \\
(\text { em milhares \$) }\end{array}$} \\
\hline & $20 \times 1$ & $20 \times 2$ & $20 \times 3$ \\
\hline LUCRO LÍQUIDO DO EXERCÍCIO & 1.000 & 1.500 & 3.000 \\
\hline (+) Depreciação & 500 & 500 & 500 \\
\hline (-) Aumento de duplicatas a receber & 300 & 150 & 250 \\
\hline (+) Diminuição dos estoques & 224 & 400 & 530 \\
\hline (+) Diminuição de fornecedores & 100 & 250 & 400 \\
\hline (+) Pagamento a funcionários & 100 & 100 & 100 \\
\hline (+) Aumento de contas a pagar e impostos & 24 & 50 & 30 \\
\hline SALDO DO FLUXO DE CAIXA OPERACIONAL (1) & 1.648 & 2.650 & 4.310 \\
\hline Venda de ativos & - & - & - \\
\hline Aquisição de ativos e investimentos & 3.000 & 1.400 & 300 \\
\hline SALDO DO FLUXO DE CAIXA DE INVESTIMENTO (2) & $(3.000)$ & $(1.400)$ & (300) \\
\hline Entrada de empréstimos & - & - & - \\
\hline Amortização de empréstimos & 3.000 & 3.000 & 3.000 \\
\hline SALDO DO FLUXO DE CAIXA DE FINANCIAMENTO (3) & $(3.000)$ & $(3.000)$ & $(3.000)$ \\
\hline GERAÇÃO DE CAIXA NO PERÍODO $(1+2+3)$ & (4.352) & $(1.750)$ & 1.010 \\
\hline Saldo inicial das disponibilidades & 10.000 & 5.648 & 3.898 \\
\hline Saldo final das disponibilidades & 5.648 & 3.898 & 4.908 \\
\hline
\end{tabular}

Fonte: Própria autoria.

Para Krishnan e Largay (2000), o método direto oferece melhor previsão de fluxo de caixa operacional futuro do que as informações ajustadas pelo método indireto. Para os autores, o demonstrativo produzido pelo método direto assegura ao gestor financeiro comparar um fluxo de caixa orçado para cada conta de receita e 
despesa, além de uma melhor representação do ciclo de caixa em um formato mais agradável para gestores que não possuem um amplo conhecimento contábil.

Por outro lado, os mesmos autores destacam que o demonstrativo pelo método indireto permite ao gestor financeiro perceber as variações das contas de capital de giro e identificar as contas que não são desembolsáveis.

Assim, embora seja evidente que a demonstração apresentada pelo método direto pode ser mais vantajosa para alguns usuários e gestores financeiros, a demonstração pelo método indireto avalia a qualidade dos lucros quando conciliada com o ajuste das contas sob regime de competência para regime de caixa e possui maior preferência de utilização em diversos países e menor custo de implantação com relação ao método direto (JEPPESON; RUDDY; SALERNO, 2016).

\subsection{Fluxo de caixa como ferramenta de gestão para pequenas e médias empresas}

Dentre diversas definições, o fluxo de caixa pode ser compreendido como a "espinha dorsal" de uma organização por demonstrar a informação de recursos necessários para sustentar as operações e o período no qual haverá a real necessidade de captar recursos para a continuidade da operação (GITMAN, 1997).

A gestão de fluxo de caixa nas pequenas e médias empresas é fundamental para assegurar o desempenho financeiro e o controle da disponibilidade de dinheiro. O benefício de uma boa gestão de fluxo de caixa é significativo, pois as PMEs, quando comparadas a empresas maiores, possuem custos de captação mais altos quando necessitam de dinheiro (TAURINGANA; AFRIFA, 2013).

Ross, Westerfield e Jordan (1998) afirmam que o fluxo de caixa pode ser considerado como um conjunto de informações mais importantes extraído das demonstrações financeiras. É por meio dele que o gestor financeiro consegue saber a quantidade de dinheiro recebida e a quantidade de dinheiro que saiu da empresa.

Assim, o fluxo de caixa se torna uma ferramenta de controle ainda mais essencial, pois consegue controlar fluxos de pagamentos e recebimentos em qualquer situação, inclusive os fluxos voláteis, que possuem fortes oscilações comprometendo a disponibilidade de dinheiro e a escassez a qualquer momento (FERREIRA; VILELA, 2004). Dessa forma, o fluxo de caixa, quando bem gerido, pode servir como um "amortecedor" contra eventos inesperados (AFRIFA, 2016). 
Sebrae (2016a) aponta que, entre os fatores que levaram à mortalidade de empresas no período de 2008 a 2012, está o fato de 65\% dos empreendedores não controlaram rigorosamente as receitas e despesas ao longo do tempo, significando que a gestão de fluxo de caixa não era utilizada para o controle da empresa.

Birley e Niktari (1996) identificaram em uma pesquisa com pequenos empreendedores que $60 \%$ dos entrevistados não planejaram a abertura do negócio, $23 \%$ disseram que fizeram retiradas acima do que a empresa poderia suportar e 33\% não possuíam competências nas áreas de finanças, tributos e jurídica.

Por isso, a gestão de fluxo de caixa está associada à disciplina do empreendedor em agir de forma profissional. Muito embora ele terceirize a responsabilidade para o contador ou para outros profissionais, é evidente que esse profissional não cuidará do negócio se não participar do dia a dia da empresa (FERREIRA et al., 2012).

Por mais que haja essa transferência de responsabilidade, os fatores associados à falência dependem da atuação do empreendedor, que possui uma tendência para influenciar o desempenho do negócio (FERREIRA et al., 2012).

Assaf Neto e Silva (2012) acrescentam que a gestão de fluxo de caixa permite prever se a empresa terá excedentes ou escassez de dinheiro em um determinado intervalo de tempo, determinando-se ações preventivas a serem implantadas.

O controle diário do fluxo de caixa tem grande relevância na gestão dos pagamentos e recebimentos perante fornecedores, governo, funcionários, sócios, clientes e outros (SEBRAE, 2016c). O descasamento de datas que o fluxo de caixa possui na entrada e saída de dinheiro, quando não controlado e gerenciado corretamente, pode causar efeitos de restrições no desempenho da empresa e na demanda de liquidez (ALMEIDA; CAMPELLO; WEISBACH, 2004).

Perez (2007) reforça que o empreendedor gera valor à empresa quando busca preservar o capital de giro, os investimentos e os financiamentos por meio da gestão de fluxo de caixa a curto prazo.

Em uma outra pesquisa realizada pelo Serviço de Apoio às Micro e Pequenas Empresas - SEBRAE (2016c) com mais de três mil empresas, foi constatado que $46 \%$ das empresas não planejam receitas e despesas para os próximos seis meses e $39 \%$ fazem o planejamento de maneira parcial. 
Quando a abordagem desta pesquisa se volta ao controle de receitas e despesas, apenas $10 \%$ das empresas realizam o controle de fluxo de caixa, e $77 \%$ não separam totalmente o dinheiro da empresa do dinheiro pessoal, como informado na Figura 4.

Figura 4 - Fatores praticados pelos empreendedores brasileiros

\begin{tabular}{|c|c|c|c|}
\hline \multicolumn{4}{|c|}{ Não Mais ou menos } \\
\hline $\begin{array}{c}\text { SEPARAM O DINHEIRO DA EMPRESA DO } \\
\text { DINHEIRO PESSOAL }\end{array}$ & $34 \%$ & $43 \%$ & $23 \%$ \\
\hline $\begin{array}{c}\text { CONTROLAM AS RECEITAS E DESPESAS } \\
\text { DAS EMPRESAS }\end{array}$ & $43 \%$ & $47 \%$ & $10 \%$ \\
\hline $\begin{array}{c}\text { PLANEJAM RECEITAS E DESPESAS DAS } \\
\text { EMPRESAS PARA } 6 \text { MESES }\end{array}$ & $46 \%$ & $39 \%$ & $15 \%$ \\
\hline $\begin{array}{l}\text { UTILIZAM PLANILHAS OU SOFTWARES PARA } \\
\text { CONTROLAR O FLUXO DE CAIXA }\end{array}$ & $15 \%$ & $53^{\circ}$ & \\
\hline
\end{tabular}

Fonte: adaptado de Sebrae (2016c).

Esses fatores praticados pelos pequenos e médios empreendedores comprometem a continuidade da empresa, conforme prevê os princípios contábeis da entidade e da continuidade, que determinam respectivamente a separação do patrimônio da empresa com a dos seus sócios e o controle das receitas e despesas para aferir a capacidade futura de geração de resultado (CFC, 2008).

Além de ser uma ferramenta utilizada para avaliação do valor da empresa ao longo do tempo, o processo de decisão pelo fluxo de caixa demonstra maior ênfase no que é de interesse e preocupação ao empreendedor: o valor de caixa disponível para investimentos e capital de giro, conforme ilustrado na Figura 5 (DAS, 2017). 
Figura 5 - Aplicação da geração de caixa

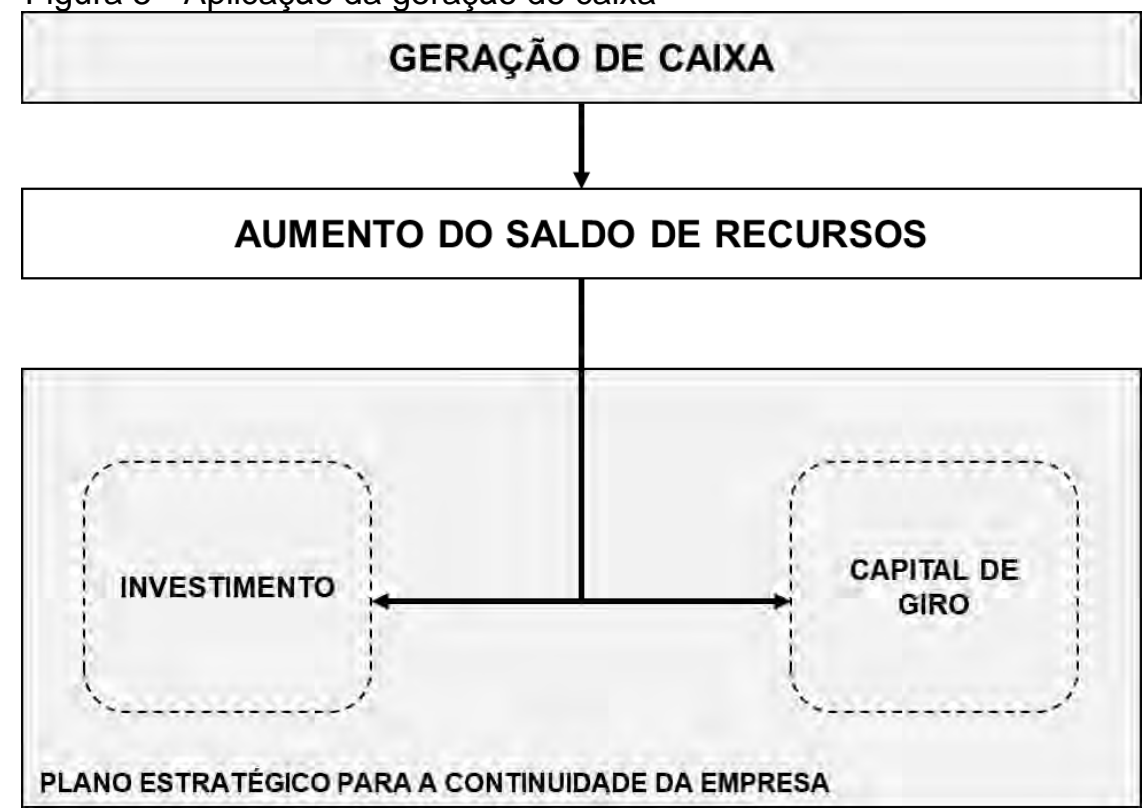

Fonte: adaptado de Das (2017).

É importante evidenciar que a utilização do fluxo de caixa contribui para a reorganização financeira e para novas estratégias ligadas a crescimento, sobrevivência e competitividade. Quando a empresa enfrenta dificuldades financeiras, é possível perceber, com a gestão de fluxo de caixa, que o montante das disponibilidades não é suficiente para cobrir os pagamentos contratados e assim sinalizar ao gestor um grave problema (ROSS; WESTERFIELD; JAFFE, 2002).

Por isso, o monitoramento do fluxo de caixa como ferramenta de gestão para pequenas e médias empresas ajuda evitar dificuldades financeiras, processo de insolvência, liquidação de ativos para pagamentos de dívidas, captação de empréstimos com juros elevados, investimentos em projetos não rentáveis, perda da eficiência operacional e falência (YAHYA; ALI; GHAZALI, 2016).

\subsubsection{A importância do plano de contas para estruturar o fluxo de caixa}

Nas pequenas e médias empresas, o empresário acaba por assumir o papel de gestor financeiro e, muitas vezes, não possui conhecimento das técnicas gerenciais e dos aspectos financeiros e contábeis do negócio devido à simplicidade com que essas empresas operam (KASSAI, 1997).

O plano de contas é uma ferramenta que pode satisfazer as necessidades gerenciais, bem como as necessidades da contabilidade financeira em conter 0 
mínimo de informações básicas para a preparação de demonstrações financeiras formais (HAYES; SILVA, 1992).

A estrutura do plano de contas permite ao gestor financeiro capturar os dados que chegam a partir dos processos de transação do fluxo de caixa deixando-os padronizados e informativos mediante a operação da empresa (SÁNCHEZRODRÍGUEZ; SPRAAKMAN, 2012).

Kassai (1997) sugere que o plano de contas contenha o número de contas mínimo com nomenclatura objetiva e de fácil compreensão para os usuários. Ainda sob a ótica da autora, o plano de contas deverá manter a essência da simplicidade das PMEs nos quesitos de não exigir conhecimentos contábeis para sua elaboração e ser intuitivo, como segue no Quadro 10.

Quadro 10 - Modelo de plano de contas

\begin{tabular}{|l}
\hline CONTRADAS \\
\hline 1. Receitas com vendas \\
1.1 Vendas à vista \\
1.2 Vendas a prazo \\
1.3 Vendas com cheque \\
1.4 Outras receitas
\end{tabular}

2. Entradas de Investimentos

GRUPO FINANCEIRO

Operacional

Investimento

2.1 Venda de imobilizado

2.2 Rendimento de aplicações financeiras

2.3 Resgate de aplicações financeiras

2.4 Outras entradas de investimentos

3. Entradas Financeiras

Financiamento

3.1 Empréstimo/Financiamento

3.2 Juros recebidos de clientes em atraso

3.3 Antecipação de vendas a prazo

3.4 Outras entradas financeiras

3.5 Aporte de capital

SAÍDAS

6. Impostos sob vendas

Operacional

6.1 ICMS

6.2 PIS

6.3 COFINS

$6.4 \mathrm{IPI}$ 
7. Custos de produção

7.1 Matéria-prima

7.2 Embalagens

7.3 Energia Elétrica

7.4 Manutenção de equipamentos

7.5 Manutenção predial da produção

7.6 Fretes insumos/mercadorias

8. Logística \& Distribuição

8.1 Combustíveis e pedágios

8.2 Manutenções de veículos

8.3 Seguros

8.4 Impostos e taxas de veículos

8.5 Multas diversas

8.6 Frete para entrega de mercadoria

\section{Folha de pagamento}

9.1 Salários e adiantamento

9.2 Férias

$9.313^{\circ}$

9.4 Vale alimentação

9.5 Vale transporte

9.6 Assistência médica

9.7 Seguros de vida em grupo

9.8 Uniformes e EPI's

9.9 Rescisões

9.10 Passivos trabalhistas

9.11 INSS

9.12 FGTS

9.13 IRRF

9.14 Cursos e Treinamentos

10. Comercial

10.1 Comissões

10.2 Propagandas e promoções

10.3 Ação de vendas em clientes

10.4 Outros

11. Ocupação \& Apoio

11.1 Aluguel do prédio

11.2 Água e esgoto

11.3 Energia elétrica

11.4 Telefonia e internet

11.5 Materiais de escritório

11.6 Materiais de cozinha e limpeza

11.7 Despesas bancárias

11.8 Manutenção predial adm.

11.9 Manutenção de equipamentos de escritório 11.10 Serviços de terceiros
Operacional

Operacional

Operacional

Operacional

Operacional 
conclusão

12. Outros impostos e contribuições

Operacional

12.1 IRPJ

12.2 CSLL s/ resultado

12.3 ITR

13. Saídas de financiamento

Financiamento

13.1 Distribuição de lucros

13.2 Pagamento de empréstimo/financiamento

13.3 Juros por atraso de pagamento

14. Saídas de investimento

Investimento

14.1 Compra de imobilizado

14.2 Construção de ativo em andamento

14.3 Aplicação financeira

Fonte: Própria autoria.

Sánchez-Rodrígues e Spraakman (2012) reforçam que uma boa construção do plano de contas pode reduzir o envolvimento de contadores no registro de informações e permitir relatórios com mais detalhes de informações.

De acordo com Hayes e Silva (1992), as informações financeiras deverão ser reportadas nos padrões dos relatórios contábeis, porém o plano de contas no formato padrão de contabilidade é muito amplo e por isso deverá ser ajustado de acordo com as implicações de cada empresa, seja aumentando ou diminuindo contas ou apenas ajustando o título das mesmas.

Para registrar as entradas e saídas no fluxo de caixa, o gestor deverá relacionar esses eventos a uma conta do plano, segundo a natureza econômica daquele evento (PARISI; CORNACHIONE JUNIOR; VASCONCELLOS, 1997).

Os autores Parisi, Cornachione Junior e Vasconcellos (1997) sugerem que:

a) o plano de contas deve atender aos objetivos e premissas do sistema de apuração;

b) a classificação deve partir dos grupos genéricos para os mais específicos;

c) a descrição das contas deve indicar com clareza a natureza econômica que será classificada nela;

d) deve ser flexível para absorver futuras alterações.

Portanto, com o plano de contas é possível ao empreendedor ou gestor financeiro acompanhar as receitas e despesas realizadas com as previstas naqueles períodos, além de facilitar o planejamento dos próximos períodos com bases nas 
informações consolidadas que apenas o plano de contas financeiro permitirá (HAYES; SILVA, 1992).

\subsubsection{Planejamento financeiro com fluxo de caixa}

Gitman (1997), caracteriza o planejamento como um aspecto importante para a continuidade e sustentação da empresa, pois fornece caminhos para dirigir, coordenar e controlar as ações alinhadas aos objetivos de curto e longo prazo.

Ross, Westerfield e Jaffe (2002) definem o planejamento como um método que estabelece as diretrizes de mudanças na empresa e de que forma as metas financeiras devem ser atingidas num período futuro, permitindo com que a empresa se discipline para direcionar suas metas.

Segundo Haskins, Higgs e Ketz (1987), planejamento financeiro requer que as pequenas, médias e grandes empresas possuam capacidade de entender as entradas e saídas de dinheiro do fluxo de caixa com as necessidades futuras, a fim de poder posicionar a empresa entre o sucesso e o fracasso.

Para planejar as necessidades futuras, o gestor financeiro reflete sua análise em resultados de eventos que já ocorreram para que consiga orientar suas projeções futuras, aproveitando também para corrigir erros cometidos no passado (CHEATHAM; CHEATHAM, 1993).

O planejamento pode ser realizado em curto e longo prazo, e o prazo adotado pelo gestor financeiro para as tomadas de decisões influencia de que forma o planejamento será elaborado. Os termos "curto prazo" e "longo prazo" se diferenciam, respectivamente, pelo período de até um ano e de dois a cinco anos (ROSS; WESTERFIELD; JAFFE, 2002).

O planejamento de longo prazo está relacionado ao planejamento estratégico da empresa. É previsto nesse planejamento os investimentos, atividades de pesquisas e desenvolvimento, ações de marketing, quitação de financiamentos, fontes de captação para novos financiamentos, lançamento de novos produtos, ampliação das estruturas de produção, novos ramos de negócios, entre outros (GITMAN, 1997).

Já o planejamento de curto prazo está ligado às operações da empresa nos próximos dozes meses, informando o montante de vendas de que a empresa necessita, o quanto precisa comprar de matéria-prima para manter a produção, se 
haverá necessidade de dinheiro no fluxo de caixa, os investimentos necessários para o período, como será a política de estocagem, entre outras situações (GITMAN, 1997).

Para planejar o fluxo de caixa é necessário projetar as vendas com seus recebimentos e os pagamentos com fornecedores, salários, impostos, despesas administrativas, despesas comerciais, investimentos, empréstimos e financiamentos para manter a empresa em operação (ROSS; WESTERFIELD; JORDAN, 1998).

O planejamento de caixa pode ser elaborado para qualquer período e é recomendado que o período projetado seja dividido em intervalos mensais para empresas que apresentam fluxos sazonais e incertos. Empresas que apresentam fluxos de caixa mais estáveis podem projetar seus resultados financeiros em intervalos trimestrais, semestrais ou anuais (GITMAN, 1997).

Planejar algo que ainda não ocorreu requer cuidado com relação a riscos e incertezas. Riscos e incertezas estão inter-relacionados, mas se diferenciam quando num planejamento, os riscos podem ser mensuráveis e as incertezas não (KNIGHT, 1964).

Assim, Ross, Westerfield e Jaffe (2002) recomendam que o processo de planejamento seja preparado em três cenários alternativos, a fim de diminuir os riscos e incertezas:

1. Pessimista: o gestor financeiro nesse plano prevê as piores projeções e riscos que a empresa pode passar durante o período, considerando liquidação de ativos para pagamentos das dívidas e encerramento das atividades.

2. Mais provável: o planejamento nesse cenário irá considerar as projeções mais prováveis com relação à empresa e o cenário econômico, apresentando maior equilíbrio entre projeções favoráveis e desfavoráveis.

3. Otimista: nesse cenário a empresa traça sua projeção com base nas hipóteses mais otimistas, prevendo expansão das operações, lançamento de novos produtos, vendas com crescimento acelerado, entre outros.

Gitman (1997) e Ross, Westerfield e Jaffe (2002) recomendam que a projeção de fluxo de caixa seja realizada por etapa, para facilitar o entendimento do gestor financeiro e prever todas as variáveis de cada etapa, conforme demonstrado na Figura 6. 
Figura 6 - Etapas de planejamento de caixa

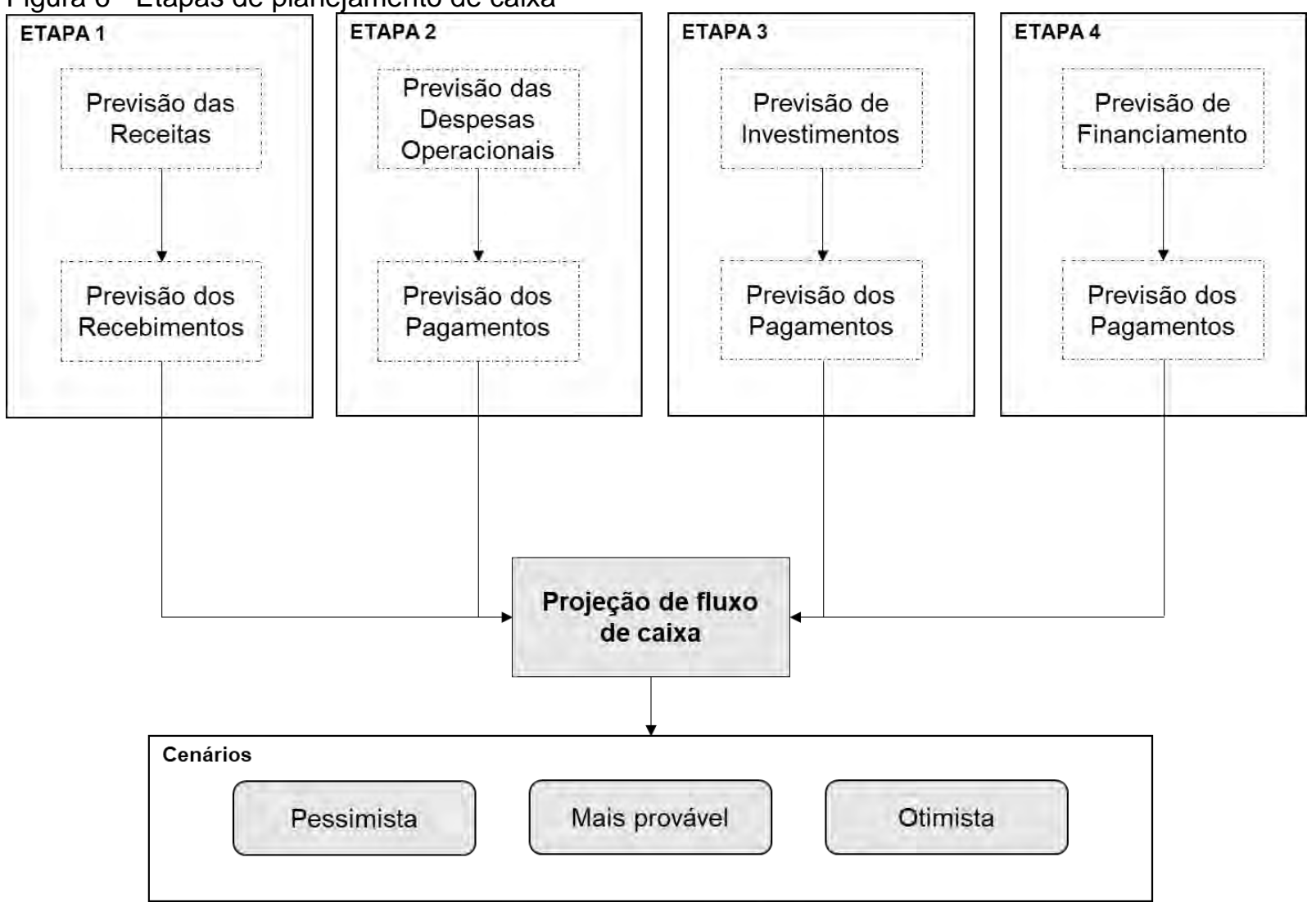

Fonte: adaptado de Gitman (1997) e Ross, Westerfield e Jaffe (2002).

Dessa forma, utilizar a ferramenta de planejamento para o fluxo de caixa seguindo cada etapa demonstrada na Figura 6 é a melhor maneira do pequeno e médio empreendedor lidar com os problemas de caixa antes que eles ocorram, evitando surpresas e decisões equivocadas (CHEATHAM; CHEATHAM, 1993).

Portanto, quando o empresário não prevê financeiramente o que ocorrerá com o seu negócio, há um alto risco em se confundir, por exemplo, com entradas de recebimentos de caixa em um período em que as vendas diminuíram e não perceber que os recebimentos são referentes a períodos anteriores, quando as vendas estavam altas, e necessitar urgentemente de uma intervenção de recursos para manter as obrigações da empresa em dia. (CHEATHAM; CHEATHAM, 1993).

\subsubsection{Ciclo operacional e de caixa para a gestão do capital de giro}

Assaf Neto e Silva (2012, p. 3) definem capital de giro como recursos correntes que podem ser convertidos em caixa em um período de curto prazo, isto é, o capital de giro "[...] representa os recursos demandados por uma empresa para 
financiar suas necessidades operacionais identificadas desde a aquisição de matérias-primas (ou mercadorias) até o recebimento pela venda do produto acabado."

As empresas podem ter um nível ótimo de capital de giro que lhes permita trabalhar com margem de liquidez e maximização do seu valor patrimonial. Porém, alguns eventos levam o gestor financeiro a tomar decisões que podem demandar um valor muito maior de investimento em capital de giro do que a empresa necessita (DELOOF, 2003).

Segundo estudo realizado por Pais e Gama (2015) com um grupo de pequenas e médias empresas portuguesas, a gestão eficiente do capital de giro tornou-se vital para o desempenho do negócio. Os resultados indicaram que uma redução no nível de estoques mantidos e da quantidade de dias que as empresas levam para pagar fornecedores e receber de clientes foram associadas a maior lucratividade financeira.

Entretanto, o capital de giro é gerado pela falta de sincronização entre as datas de recebimentos e de pagamentos da empresa, podendo ser positivo quando os recebimentos são maiores que os pagamentos ou negativo quando os pagamentos são maiores do que os recebimentos (ASSAF NETO; SILVA, 2012).

Ross, Westerfield e Jaffe (2002) afirmam que as finanças a curto prazo garantem as atividades operacionais a curto prazo, e o capital de giro tem forte relação com a lucratividade financeira da empresa, que pode ser melhor gerida pelo gestor a partir da sequência de eventos e decisões que segue no Quadro 11.

Quadro 11 - Eventos e decisões de capital de giro

Eventos

Decisões

1. Compra de insumos para a produção Qual o volume de estoque necessário?

2. Pagamento de fornecedores Precisará de empréstimo ou possui saldo de caixa?

3. Linha de produção Qual tecnologia de produção será

3. Linha de produção utilizada? Será necessário comprar novas máquinas ou equipamentos?

4. Vendas

As vendas serão à vista ou a prazo para os clientes?

5. Recebimentos de vendas

Como será cobrado? Qual o prazo?

Fonte: adaptado de Ross, Westerfield e Jaffe (2002, p. 602) 
A fim de garantir as atividades operacionais a curto prazo, a administração eficiente do caixa é medida por meio do ciclo operacional e do ciclo de caixa. O ciclo operacional é compreendido pelo período de tempo em que a empresa adquire a matéria-prima, produz, estoca, vende e recebe do seu cliente. O ciclo operacional para uma empresa industrial pode ser determinado pelo seguinte cálculo (GITMAN, 1997; ASSAF NETO; SILVA, 2012):

$$
\text { CICLO OPERACIONAL }=\text { PME }+ \text { PMF + PMV + PMR }
$$

onde:

$\mathrm{PME}=$ prazo médio de estocagem das matérias-primas, apurado pelo seguinte cálculo:

PME $=\frac{\text { Estoque de matéria-prima }}{\text { Consumo de matéria-prima }} \times 360^{5}$

PMF = prazo médio de fabricação, apurado pelo seguinte cálculo:

$$
\mathbf{P M F}=\frac{\text { Estoque de produto em processo }}{\text { Custo dos produtos elaborados }} \times 360
$$

PMV = prazo médio de venda, apurado pelo seguinte cálculo:

$$
\mathbf{P M V}=\frac{\text { Estoque de produto acabado }}{\text { Custo do produto vendido }} \times 360
$$

PMR = prazo médio de recebimento, apurado pelo seguinte cálculo:

PMR = Contas a receber Vendas $\times 360$

\footnotetext{
${ }^{5}$ Para prazos médios mensais, considerar 30 dias ao invés de 360 dias (anual).
} 
O ciclo de caixa, conhecido também como ciclo financeiro, compreende o período entre o pagamento de fornecedores de insumos (matéria-prima e mão-deobra) e o recebimento das vendas dos produtos produzidos. O cálculo do ciclo de caixa é obtido pela fórmula (GITMAN, 1997; ROSS; WESTERFIELD; JAFFE, 2002):

CICLO DE CAIXA = CICLO OPERACIONAL - PMPF

onde:

PMPF = prazo médio de pagamento de fornecedores, apurado pelo seguinte cálculo:

$\mathbf{P M P F}=\frac{\text { Fornecedores a pagar }}{\text { Compras }} \times 360$

A Figura 7 representa graficamente o ciclo operacional e de caixa de uma empresa industrial.

Figura 7 - Ciclo operacional e de caixa

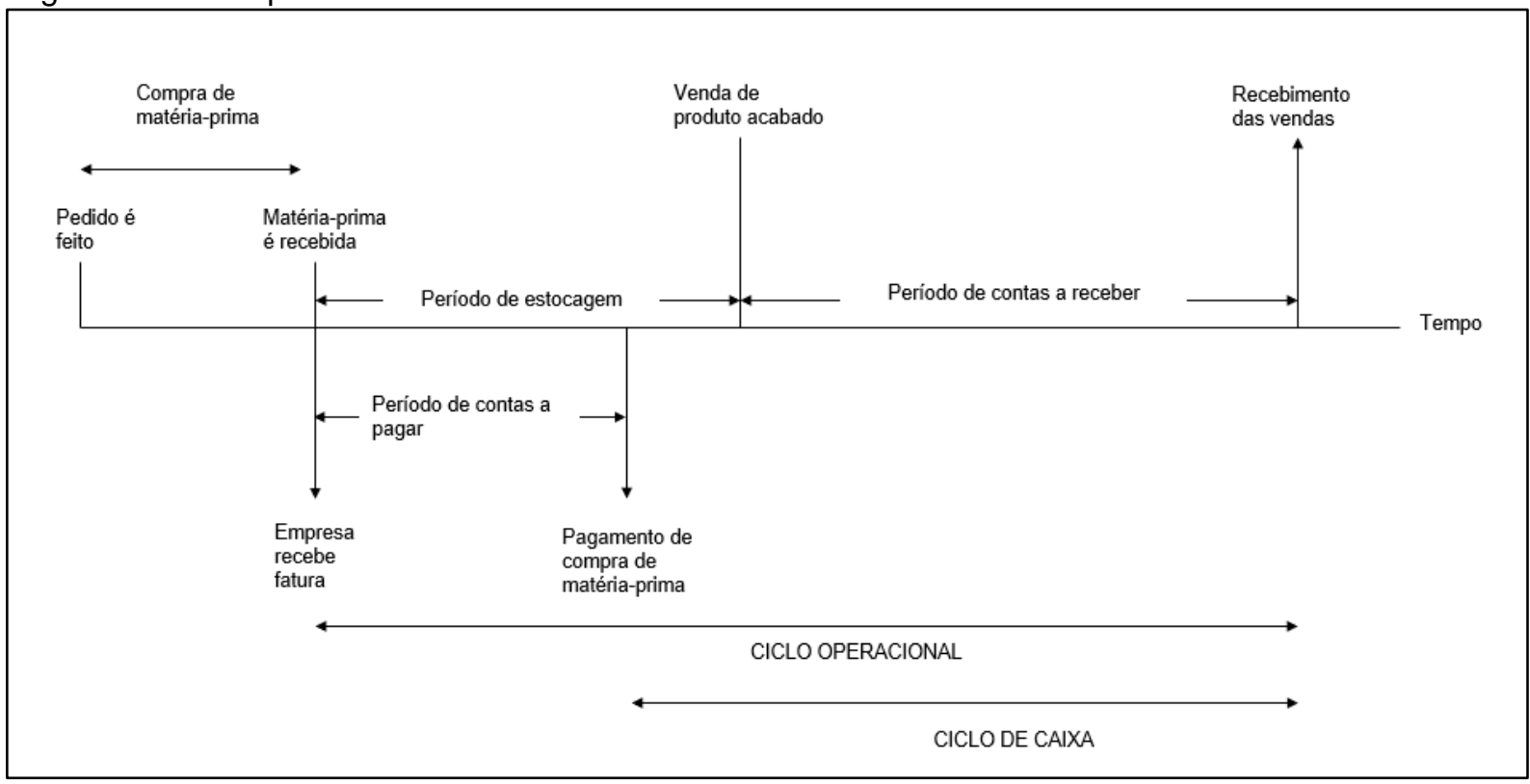

Fonte: ROSS, S. A.; WESTERFIELD, R. W.; JAFFE, J. F. Administração financeira. 2. ed. São Paulo: Atlas, 2002, p.603.

Quando a empresa apresenta um ciclo de caixa positivo, o gestor financeiro precisará se utilizar de empréstimos para financiar o ciclo de caixa. Neste caso, ao investir no capital de giro e formar o montante necessário para suportar esse 
período, evita a empresa recorrer a empréstimos com custos de juros elevados (GITMAN, 1997; PAIS; GAMA, 2015).

A condição ideal para qualquer empresa seria os prazos médios de pagamentos serem maiores que o ciclo operacional, eliminando dessa forma 0 investimento em capital de giro ou captação de empréstimos. Nessa situação, a empresa pode beneficiar-se utilizando essas fontes de recursos para dar sustentação a outras necessidades do negócio para melhor desempenho, além do ciclo operacional (GITMAN, 1997).

Portanto, Gitman (1997) reforça que o gestor financeiro deve visar estratégias que minimizem a quantidade de dias necessárias para financiar o ciclo de caixa sem prejudicar as vendas e sintetiza essas estratégias em três pontos:

1. Renovar os estoques tão rápido quanto possível, a fim de evitar a falta de estoques e prejudicar as vendas da empresa;

2. Diminuir o prazo de recebimento de vendas sem motivar quedas no volume de vendas e pressão exagerada nos clientes. Descontos financeiros durante as vendas, desde que sejam economicamente viáveis podem ser utilizados para atingir esse objetivo e;

3. Alongar o prazo de pagamento de contas a pagar ao máximo possível, sem prejudicar o crédito da empresa com o fornecedor, e sempre negociar descontos favoráveis.

2.4.4 Dimensionamento do capital de giro e cálculo dos prazos médios

Segundo Hill, Kelly e Highfield (2010), adotar políticas de capital de giro durante o ciclo operacional permite à empresa administrar as variáveis do mercado e acumular benefícios que afetam o fluxo de caixa.

Para os autores, o comportamento do capital de giro é influenciado pelas capacidades de financiamento que a empresa possui. Empresas com menor capacidade de financiamento, acesso limitado a instituições bancárias e altas taxas de juros para obtenção de recursos financeiros requerem uma política de capital de giro mais intensa.

Assaf Neto e Silva (2012) propõe o método Fleuriet para aplicar o dimensionamento do capital de giro em empresas brasileiras. O método utiliza as estruturas do Balanço Patrimonial da empresa para quantificar a necessidade de 
capital de giro. O Quadro 12 determina os principais valores que o gestor financeiro necessita para o cálculo.

Quadro 12 - Grupos patrimoniais de capital de giro

\begin{tabular}{|c|c|c|c|c|c|}
\hline & & ATIVO & PASSIVO & & \\
\hline$\sum_{\frac{1}{4}}^{\text {W }}$ & 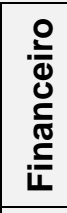 & $\begin{array}{l}\text { Caixa e Bancos } \\
\text { Aplicações Financeiras }\end{array}$ & \begin{tabular}{|l|} 
Empréstimos Bancários \\
Financiamentos \\
Duplicatas Descontadas \\
Dividendos e Imposto de Renda
\end{tabular} & 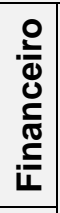 & 宸 \\
\hline 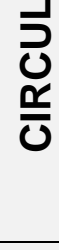 & $\begin{array}{l}\frac{\pi}{c} \\
\frac{0}{0} \\
\frac{\pi}{0} \\
\frac{0}{0} \\
\text { 은 }\end{array}$ & $\begin{array}{l}\text { Duplicatas a Receber } \\
\text { Estoque de Produto Acabado } \\
\text { Estoque de Insumos } \\
\text { Adiantamento de Despesas de } \\
\text { competência do período seguinte }\end{array}$ & $\begin{array}{l}\text { Fornecedores } \\
\text { Salários e Encargos } \\
\text { Impostos e Taxas } \\
\text { Adiantamento de Clientes }\end{array}$ & $\begin{array}{l}\bar{\pi} \\
\frac{0}{0} \\
\frac{\pi}{0} \\
\frac{\pi}{d} \\
\overline{0}\end{array}$ & 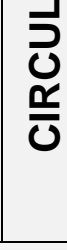 \\
\hline & $\frac{1}{\frac{1}{4}}$ & $\begin{array}{l}\text { Máquinas e Equipamentos } \\
\text { Imóveis } \\
\text { Outros itens de longo prazo }\end{array}$ & $\begin{array}{l}\text { Passivo não circulante } \\
\text { Patrimônio Líquido }\end{array}$ & & 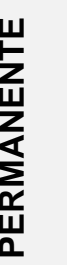 \\
\hline
\end{tabular}

Fonte: ASSAF NETO, A.; SILVA, C. A. T. Administração do capital de giro. 4. ed. São Paulo: Atlas, 2012, p. 66.

Os autores agrupam as contas de Ativo e Passivo em grupos que denominam em Circulante e Permanente. O grupo Circulante é dividido em dois subgrupos: financeiro e operacional.

O subgrupo financeiro é formado por contas que não apresentam necessariamente um vínculo com o ciclo operacional da empresa enquanto o subgrupo operacional é formado por valores que estão diretamente relacionados ao ciclo operacional da empresa. O grupo Permanente é composto por bens, direitos e obrigações que a empresa possui a longo prazo, isto é, acima de 12 meses (ASSAF NETO; SILVA, 2012).

Assim, as atividades operacionais da empresa podem criar um fluxo de caixa, cujas saídas de dinheiro acontecem de forma mais rápida do que as entradas. Dessa forma, a empresa passa a ter uma necessidade permanente de investimento em capital de giro (NIG) e o gestor consegue saber o montante necessário com o seguinte cálculo utilizando as informações do Quadro 12 (ASSAF NETO; SILVA, 2012): 
NIG = Ativo Circulante Operacional - Passivo Circulante Operacional

Quanto menor o valor do NIG, menor será o investimento em capital de giro, enquanto que o inverso também é verdadeiro, isto é, quanto maior o valor do NIG, maior será o investimento em capital de giro (AFRIFA, 2016).

O NIG também pode ser negativo e, nesse caso, a empresa não necessita de investir em capital de giro. Isso ocorre porque as contas do passivo circulante relacionadas à operação estão financiando não somente as contas do ativo operacional como também do financeiro e do permanente. Por exemplo, em uma empresa que recebe suas vendas com 30 dias e realiza os pagamentos com 45 dias, o dinheiro entra primeiro no caixa, para depois ser empenhado para algum pagamento e, por isso, compõe o saldo bancário ou de caixa localizados no grupo do ativo financeiro (ASSAF NETO; SILVA, 2012).

O pequeno e médio empreendedor necessita entender, por exemplo, como o crescimento das vendas pode influenciar no investimento em capital de giro (NIG). Muito embora o crescimento de vendas com a necessidade de capital de giro pode apresentar uma relação inversa, empresas podem adotar uma política de cobrança, estoque e de pagamentos que influencia no capital de giro, à medida em que alcançam os níveis planejados de crescimentos de vendas (HILL; KELLY; HIGHFIELD, 2010).

Calculado o NIG, o gestor financeiro já tem conhecimento do valor mínimo de capital de giro, conhecido também como capital circulante líquido, que a empresa necessita para manter suas atividades operacionais. Porém, o gestor necessita saber o quanto a empresa possui de capital de giro e não apenas o valor mínimo. Portanto, para encontrar o montante de capital de giro presente, a fórmula de cálculo será (ASSAF NETO; SILVA, 2012):

CAPITAL DE GIRO LÍQUIDO (CDG) = Ativo Circulante - Passivo Circulante

O CDG pode ser positivo ou negativo. Quando positivo demonstra que a empresa possui capacidade financeira de manter todo o ciclo operacional. Quando 
negativo, o passivo circulante é maior que o ativo circulante indicando que a empresa está utilizando de recursos de curto prazo para financiar recursos de longo prazo comprometendo a liquidez financeira do negócio (ASSAF NETO; SILVA, 2012).

Assim, uma política de capital de giro mais restritiva com prazos de cobranças, prazos de pagamentos, prazos de estocagem e prazos de crédito pode ser uma resposta às empresas que apresentam escassez de capacidade financeira e de geração de caixa operacional (HILL; KELLY; HIGHFIELD, 2010).

Entretanto, para os pesquisadores Hill, Kelly e Highfield (2010) empresas que apresentam vendas voláteis e dificuldades financeiras tendem a reduzir 0 investimento em capital de giro, utilizando apenas o capital de giro disponível de forma mais intensa, a fim de incrementar o fluxo de caixa. Porém, é importante que o gestor se atente ao nível de investimento de capital de giro (NIG) e de capital de giro (CDG), que podem ser sazonais.

Assaf Neto e Silva (2012) afirmam que a maneira mais simples de dimensionar o capital de giro sazonal é mensurar a operação da empresa em períodos de menor e maior volume.

Aktas, Croci e Petmezas (2015) afirmam que em empresas com capital de giro baixo, o investimento em capital de giro e investimentos em ativos fixos (máquinas, equipamentos, patentes, entre outros) podem melhorar o desempenho da empresa.

Entretanto, para não comprometer o investimento em capital de giro com investimentos em ativos fixos (AKTAS; CROCI; PETMEZAS, 2015), o gestor poderá adicionar ao valor da NIG o montante necessário para investir em ativos fixos. Para isso, a fórmula da Necessidade Total de Financiamento Permanente (NTFP) será a seguinte (ASSAF NETO; SILVA, 2012):

$$
\text { NTFP = NIG + Investimentos não circulante }
$$

Portanto, calculado a NIG e o CDG, o gestor financeiro pode concluir que a empresa mantém um saldo de disponível (SD) positivo para uma reserva financeira, a fim de cobrir novos investimentos em capital de giro que podem ocorrer com eventos de natureza sazonal e assegurar oscilações na NIG. O saldo de disponível 
pode ser calculado pela diferença do CDG e da NIG, isto é (ASSAF NETO; SILVA, 2012):

$$
S D=C D G-N I G
$$

ou, para o cálculo do saldo disponível considerando os investimentos permanentes:

$$
S D=C D G-N T F P
$$

Sendo assim, o gestor financeiro necessita compreender que as necessidades temporárias que exigem maior empenho do capital de giro podem ser cobertas até o limite do saldo de disponível, devendo prever o recomposição do SD o mais breve possível, pois seu valor negativo poderá, quando não administrado corretamente, comprometer a continuidade das operações da empresa (ASSAF NETO; SILVA, 2012).

\subsubsection{Saldo mínimo de caixa}

A incerteza pode levar a situações em que, algumas vezes, a empresa tem mais gastos do que o planejado. Por isso, empresas com maior incerteza de caixa devem reter mais dinheiro em caixa (OPLER et al., 1999).

É importante a empresa atentar-se aos níveis de estoque, aos prazos de pagamentos e recebimentos de clientes e à necessidade de um saldo mínimo de caixa (SEBRAE, 2016c).

Keynes (1982) define três motivos que direcionam o empreendedor a gerir uma empresa com um saldo mínimo de caixa. O primeiro motivo está relacionado ao negócio. A empresa necessita ter recursos líquidos para assegurar o intervalo que ocorre entre o momento de pagamentos das despesas e o recebimento de vendas devido à falta de sincronia presente no fluxo de caixa. O segundo motivo está relacionado à precaução. Devido aos riscos e incertezas presentes na execução de um planejamento financeiro, a empresa deve se precaver em relação aos eventos inesperados que podem surgir durante as atividades operacionais e surpreender 0 
gestor se este não tiver um saldo mínimo de caixa. E como último motivo, o autor recomenda à empresa ter uma reserva para garantir oportunidades que se apresentam ocasionalmente com condições vantajosas.

O cálculo de saldo mínimo de caixa para os pequenos e médios empreendedores podem ser complexos quando adotados modelos matemáticos que envolvem conhecimentos estatísticos. Assaf Neto e Silva (2012), definem uma forma simples de estabelecer o valor mínimo de dinheiro que a empresa deverá manter em caixa, conforme segue nas fórmulas (13) e (14):

onde,

$$
\text { Giro de Caixa }=\frac{360 \text { dias }^{6}}{\text { Ciclo de caixa }}
$$

Assim, como o saldo mínimo de caixa é obtido pela divisão do total de pagamentos pelo giro de caixa, quanto maior for o giro menor será o valor de saldo mínimo de caixa e dessa forma o gestor pode buscar a eficiência do giro de caixa diminuindo os prazos médios que compõe o ciclo de caixa. Portanto, devido à simplicidade do cálculo, o resultado obtido deve ser adotado com cautela pelo gestor financeiro que também deve avaliar se os resultados estão próximos da realidade dos negócios da empresa (ASSAF NETO; SILVA, 2012).

\subsubsection{Indicadores financeiros a partir do fluxo de caixa}

Desenvolvidos como uma ferramenta de análise de crédito de curto prazo, os indicadores foram traçados desde o final do século XIX. Desde então, os analistas

\footnotetext{
${ }^{6}$ Caso o ciclo de caixa esteja calculado mensalmente, considerar 30 dias ao invés de 360 dias (anual).
} 
elaboraram muitos indicadores financeiros que são utilizados amplamente por profissionais e pesquisadores atualmente (GIACOMINO; MIELKE, 1993).

A análise por meio de indicadores é utilizada para comparar o desempenho e a situação da empresa ao longo do tempo. O gestor financeiro consegue avaliar se a empresa está evoluindo conforme o planejado, comparando o desempenho atual com o desempenho do passado (GITMAN, 1997).

Esse tipo de comparação forma um conjunto de tendências que ajudará o empreendedor no planejamento futuro. Uma comparação entre indicadores atuais, indicadores passados e indicadores futuros pode sinalizar ao gestor um otimismo exagerado ou uma disparidade de informação nos resultados futuros (GITMAN, 1997).

Segundo Gitman (1997) e Ross, Westerfield e Jaffe (2002) os indicadores financeiros podem ser subdivididos em quatro categorias: indicadores de liquidez, indicadores de atividade, indicadores de endividamento e indicadores de lucratividade.

Os indicadores de liquidez medem a capacidade de a empresa honrar com suas obrigações de curto prazo na data de vencimento (GITMAN, 1997). Os indicadores de atividade medem a eficácia de várias contas, como por exemplo, contas de estoque, clientes a receber, fornecedores a pagar, que foram usadas para gerar vendas ou caixa. (ROSS; WESTERFIELD; JAFFE, 2002).

Os indicadores de endividamento demonstram o montante de recursos de terceiros (bancos, sócios, fornecedores entre outros) que a empresa está utilizando para gerar resultados. Além do interesse do gestor, os credores também se interessam pelo grau de endividamento que a empresa possui, pois para eles, no caso de um volume maior de endividamento, há a probabilidade de a empresa não conseguir honrar com os seus compromissos (GITMAN, 1997).

Finalmente, os indicadores de lucratividade demonstram o lucro contábil obtido pela diferença entre as receitas e despesas. Entretanto, não há um padrão determinado para analisar o quanto a empresa é rentável, pois o ambiente dinâmico de negócios permite à empresa sacrificar resultados em certo período na expectativa de resultados futuros. Portanto, uma empresa somente pode ser rentável economicamente para os sócios ou acionistas quando sua rentabilidade for maior que a rentabilidade do mercado de capitais (ROSS; WESTERFIELD; JAFFE, 2002). 
Gitman (1997) recomenda que, ao analisar os indicadores financeiros, o gestor deve se precaver com alguns pontos:

1. Não utilizar um único indicador para avaliar o desempenho da empresa;

2. A comparação de indicadores em períodos distintos deve equiparar 0 mesmo período, como por exemplo dezembro de 20x5 com dezembro de $20 \times 4$, pois comparar períodos em que tem sazonalidade com períodos fora da sazonalidade pode conduzir a conclusões e decisões equivocadas;

3. A base de informação deve ser auditada e validada para que os indicadores reflitam a situação real da empresa;

4. Os registros financeiros utilizados devem seguir os mesmos critérios contábeis, sem a exceção de uso de tratamentos contábeis diferenciados;

5. Ao comparar os indicadores da empresa com indicadores de outra empresa, deve-se atentar à inflação, ao ramo de atividade, ao tempo de existência da empresa, aos critérios contábeis, entre outros fatores.

Embora existam inúmeros meios pelos quais o fluxo de caixa pode ser utilizado como um critério de avaliação do desempenho da empresa (DAS, 2017), Giacomino e Mielke (1993) propõem indicadores financeiros a partir do fluxo de caixa das atividades operacionais e os classificam em indicadores de suficiência e eficiência.

Os indicadores de suficiência medem a capacidade da empresa de gerar dinheiro suficiente para pagar suas obrigações, reinvestir na operação e realizar distribuição de lucros para os sócios. Esses indicadores fornecem uma visão mais detalhada para os sócios e credores com relação à quantidade de recursos disponíveis no caixa. Já os indicadores de eficiência medem a capacidade da empresa em gerar caixa a partir das vendas e do uso dos seus ativos (GIACOMINO; MIELKE, 1993).

Com base nos indicadores financeiros, Das (2017) contribui com a validação de mensurar o desempenho de uma empresa utilizando indicadores a partir do fluxo de caixa das atividades operacionais e indicadores de suficiência e eficiência propostos por Giacomino e Mielke (1993).

O Quadro 13 demonstra os principais indicadores financeiros propostos por Das (2017) e Giacomino e Mielke (1993) e Gitman (1997). 
Quadro 13 - Indicadores financeiros

INDICADORES

INTERPRETAÇÃO

Indicadores de Liquidez

$\begin{aligned} \text { Liquidez de caixa } & =\frac{\text { Fluxo de caixa operacional }}{\text { Passivo circulante }} \\ \text { Liquidez corrente } & =\frac{\text { Ativo circulante }}{\text { Passivo circulante }} \\ \text { Liquidez seca } & =\frac{\text { Ativo circulante }- \text { Estoques }}{\text { Passivo circulante }}\end{aligned}$

Indicadores de Solvência

Solvência $=$

Fluxo de caixa operacional

Passivo total

Solvência Juros =

Fluxo de caixa operacional

Juros
Esse indicador demonstra se a empresa está gerando caixa suficiente para atender suas obrigações de curto prazo. Quanto maior o resultado, melhor a posição de liquidez.

Mede a capacidade da empresa em pagar suas obrigações a curto prazo. Quanto maior o resultado, menor a dependência da empresa com capital de giro.

Possui o mesmo objetivo da liquidez corrente, porém com a exclusão dos saldos de estoque, por ser um ativo de menor liquidez.

Mede a capacidade da empresa em atender suas obrigações de curto e longo prazo apenas com o fluxo de caixa operacional. Quanto maior o resultado, melhor a posição de liquidez.

Mede a margem de segurança que a empresa pode pagar de juros de dívida pendente durante um determinado período que necessita para sobreviver a dificuldades financeiras futuras. Resultado $<1$ indica que a empresa não está gerando vendas suficientes para pagar as despesas com juros.

continua 
Indicadores de Rentabilidade
Fluxo de caixa sob receitas $=$

Fluxo de caixa operacional

Total de receitas
Lucro líquido

Vendas

Margem bruta $=$

Lucro bruto

Vendas
Esse indicador mede o quanto a empresa consegue converter de vendas em caixa. Quanto maior o resultado melhor o desempenho da empresa. Não há um padrão para a margem de fluxo de caixa com relação às vendas.

Mede a capacidade da empresa de gerar lucro após a dedução de todas as despesas e impostos sob lucros.

Mede a capacidade da empresa em pagar suas despesas fixas após os custos de produção dos produtos vendidos. Quanto maior o resultado, menor o custo relativo aos produtos vendidos.

Indicador de Eficiência

Retorno do fluxo de caixa sob Ativos =

Fluxo de caixa operacional

Total de ativos
Esse indicador determina o montante de caixa operacional que a empresa está gerando em proporção ao seu ativo. Permite avaliar as decisões de negócios da empresa em relação à capitalização. 
Indicadores de Suficiência

Capacidade de pagar dívidas $=$

Pagamento de dívidas

Fluxo de caixa operacional

Fluxo de caixa operacional

Capacidade de investimentos $=$
Esse indicador monitora o quanto a empresa necessita de caixa operacional para o pagamento de dívidas da empresa. Quanto menor o resultado, menor a dependência do caixa com dívidas.

Esse indicador demonstra a capacidade do fluxo de caixa operacional em manter os investimentos e distribuição de lucros aos sócios. Resultado > 1 indica que a empresa apresenta boa saúde financeira enquanto o resultado $<1$ indica que problemas de liquidez.

Fonte: adaptado de Das (2017), Giacomino e Mielke (1993) e Gitman (1997). 
A fim de fortalecer o ponto de vista da gestão corporativa e o papel dos auditores e contadores mostrando sinais vermelhos ou sinais de fraude em relação a acontecimentos incomuns e inesperados, a análise de indicadores é um método eficaz para avaliar as informações financeiras, pois reduz os dados a um conjunto de informações interligadas que destacam as operações e os resultados das práticas de gerenciamento de fluxo caixa da empresa (DAS, 2017). 


\section{MATERIAL E MÉTODOS}

A partir da perspectiva da estrutura metodológica, este trabalho abordou uma análise de modo qualitativo e com objetivo exploratório e descritivo. Segundo Godoy (1995, p.21), a pesquisa qualitativa possibilita "[...] estudar os fenômenos que envolvem os seres humanos e suas intrincadas relações sociais, estabelecidas em diversos ambientes." Portanto, estando o processo da pesquisa qualitativa relacionado com a interpretação dos fenômenos e seus significados, não há a necessidade da aplicação de métodos e técnicas estatísticas.

Uma pesquisa também pode ser classificada com base em seus objetivos ou procedimentos técnicos adotados. Todavia, é necessário definir um modelo conceitual e operativo que irá delinear a pesquisa quando o pesquisador analisa a visão teórica com os dados da realidade (GIL, 2002). "Como o delineamento expressa em linhas gerais o desenvolvimento da pesquisa, com ênfase nos procedimentos técnicos de coleta e análise de dados, torna-se possível, na prática, classificar as pesquisas segundo o seu delineamento" (GIL, 2002, p.43).

Assim, como delineamento para esse trabalho foi adotado a técnica da pesquisa ação, que Kemmis e McTaggart definem como:

Action research is a form of collective, self-reflective inquiry that participants in social situations undertake to improve: (1) the rationality and justice of their own social or educational practices; (2) the participants' understanding of these practices and the situations in which they carry out these practices. Groups of participants can be teachers, students, parents, workplace colleagues, social activists or any other community members - that is, any group with a shared concern and the motivation and will to address their shared concern. The approach is action research only when it is collaborative and achieved through the critically examined action of individual group members. (KEMMIS; MCTAGGART, 1988, p.5)

French (2009) descreve a pesquisa ação como uma ferramenta metodológica apropriada para pesquisas relacionadas à gestão e organização no campo empresarial. $\mathrm{O}$ autor analisa diversos pesquisadores que expõem algumas razões pelas quais a pesquisa ação é atraente para o ambiente corporativo, pois: 
- Utiliza os pesquisadores como parte integrante da pesquisa e não apenas como observadores: eles trabalham ativamente para fazerem a ação acontecer;

- Foca na experiência profissional do pesquisador, ao invés de considerações metodológicas;

- Permite que os pesquisadores pesquisem suas próprias atividades profissionais;

- Ajuda a promover melhores práticas no local de trabalho;

- Busca o desenvolvimento profissional dos envolvidos, examinando criticamente suas crenças e práticas;

- Ajuda os gestores a serem multidisciplinares e trabalharem com questões técnicas, culturais e funcionais;

- Apoia o pesquisador e os gestores a implementarem mudanças de formas eficazes, buscando mudar o modo de agir e de pensar por meio da pesquisa;

- Foca na situação-problema, mas com orientação para o futuro; e

- Contribui para o desenvolvimento de uma compreensão holística.

Coghlan e Brannick (2001) e Moss, Alho e Alexander (2007) reforçam que a pesquisa ação pode ser baseada em uma relação colaborativa para a solução de um problema entre o pesquisador e um cliente, visando não apenas resolver o problema, como também gerar novos conhecimentos.

Portanto, a escolha pelo método da pesquisa ação para esse trabalho foi motivada por duas situações: (1) pelo envolvimento do pesquisador em um projeto de reestruturação financeira como atividade profissional; (2) pelo interesse em aprofundar o conhecimento científico da modelagem do fluxo de caixa para tomada de decisão em pequenas e médias empresas.

Para aplicar a metodologia da pesquisa ação, Coughlan e Coghlan (2002) propõem que seja realizado um processo cíclico conforme ilustrado na Figura 8: 
Figura 8 - Ciclo da pesquisa ação

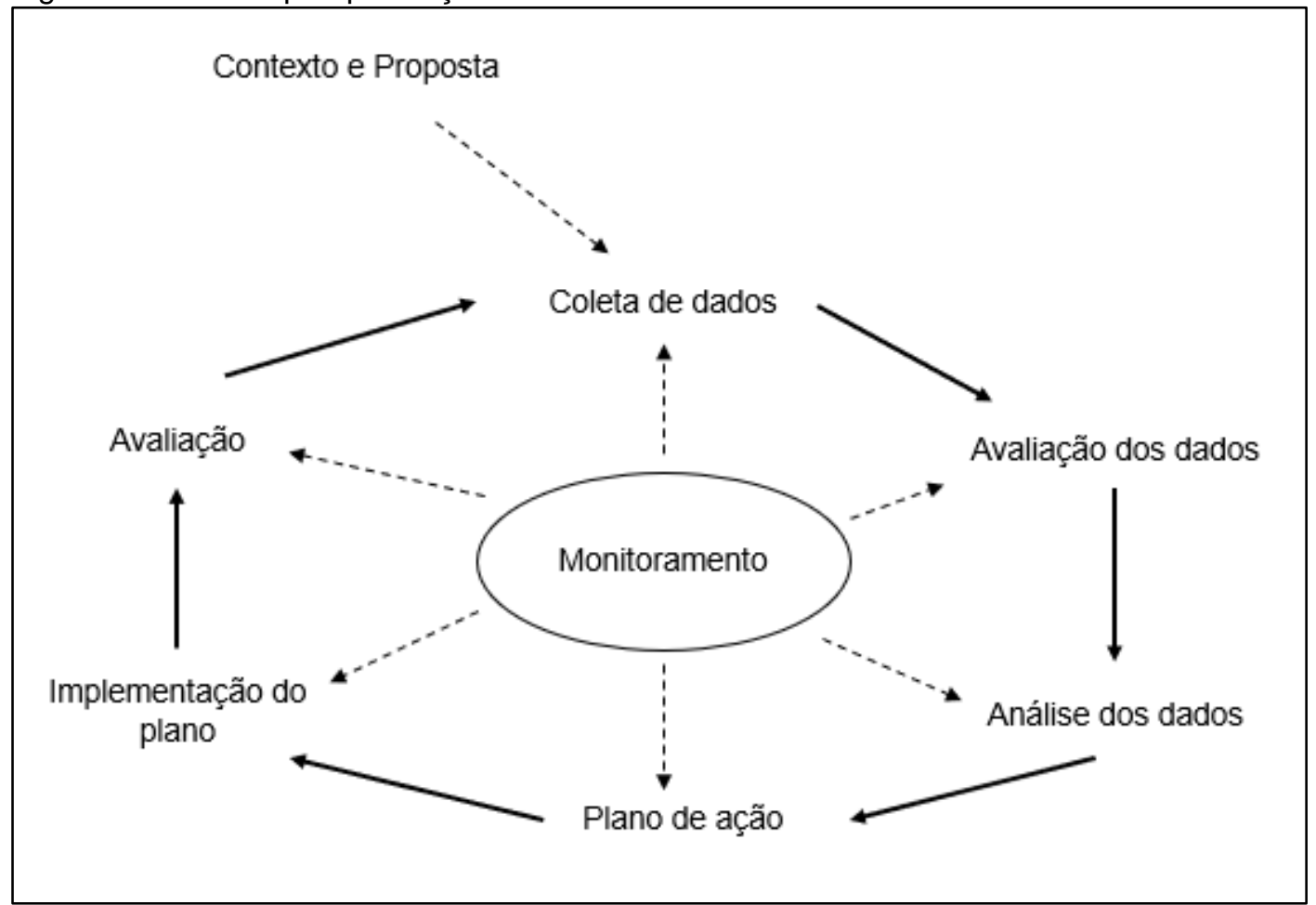

Fonte: COUGHLAN, P.; COGHLAN, D. Action research for operations management. International Journal of Operations \& Production Management, v. 22, n. 2, p.220-240, 2002.

Também foi utilizado para esse trabalho algumas ferramentas e técnicas para o levantamento das informações da empresa pesquisada, tais como:

a) Entrevistas semiestruturadas com os diretores-proprietários;

b) Reuniões com os diretores e funcionários da empresa;

c) Conversas informais;

d) Observação do pesquisador;

e) Revisão teórica sobre agronegócio, pequenas e médias empresas, produtor rural e gestão financeira;

f) Levantamento de informações documentais.

De acordo com o processo cíclico da pesquisa ação, para cada etapa será descrito como as ferramentas e técnicas de levantamento das informações foram aplicadas, a forma que os dados foram disponibilizados e o plano de ação que o pesquisador aplicou na situação-problema.

3.1 Etapas de implementação da pesquisa ação

Etapa 1 - Contexto e Proposta 
Essa etapa inicial da pesquisa ação tem por objetivo interligar o pesquisador ao contexto e à proposta do projeto de ação. Coughlan e Coghlan (2002) recomenda o pesquisador a direcionar sua pesquisa ação com base em duas perguntas:

- Por que o projeto é necessário ou desejável?

- Quais são as forças econômicas, sociais, políticas e técnicas que necessitam de uma ação?

Com base nessas questões, a primeira reunião realizada com os diretores na empresa, objeto de estudo, foi estruturada como uma entrevista com duas perguntas a eles: (1) Quais os motivos que levaram a empresa a buscar um apoio externo para a gestão? (2) Quais as principais decisões tomadas que contribuíram para o cenário atual?

Para melhor entendimento do contexto da empresa na visão dos colaboradores, o pesquisador reuniu-se também à equipe administrativa e de produção, a fim coletar informações da empresa de diversas fontes. A reunião com os colaboradores foi dividida em duas partes: a primeira parte tinha a presença dos diretores para a apresentação da proposta do projeto e do pesquisador como membro de equipe, e a segunda parte apenas com os colaboradores e o pesquisador, a fim de não os inibir com a presença dos diretores e não causar viés na coleta de informações sobre a empresa a partir do ponto de vista dos colaboradores.

\section{Etapa 2 - Coleta de dados}

Essa etapa foi considerada a principal etapa para o pesquisador. Com base nas entrevistas e reuniões iniciais que ocorreram na etapa 1, a pesquisa começou a ter as primeiras informações e dados da empresa.

Além dessas reuniões iniciais, o pesquisador se reunia de duas a três vezes por semana nos primeiros trinta dias do início do projeto com os diretores e funcionários para coleta de dados. As reuniões duravam entre 30 e 90 minutos. 0 objetivo dessas reuniões era aprofundar o conhecimento do pesquisador nos processos e atividades da empresa e perscrutar as informações com relação à veracidade das mesmas, a fim de planejar as ações corretamente para a situaçãoproblema. A pesquisa ocorreu entre os meses de julho de 2016 a dezembro de 2017, conforme demonstrado na Figura 9. 
Figura 9 - Linha cronológica da pesquisa

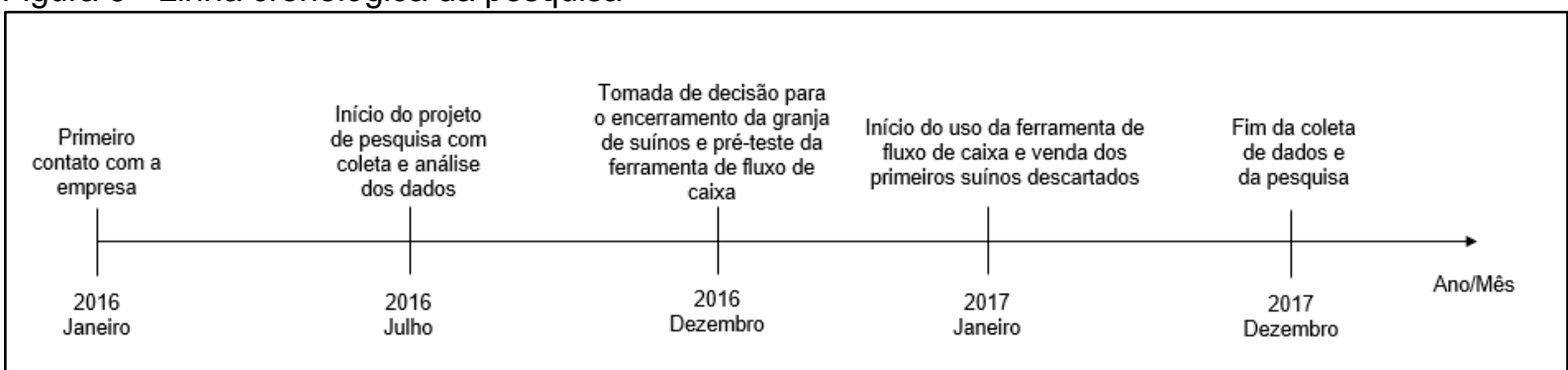

Fonte: Própria autoria

Como complemento na coleta de dados, o pesquisador utilizou informações do software ERP da empresa, controles gerenciais, relatório e documentos que podiam ser utilizados para a pesquisa. Grande parte das informações foram coletadas por meio da observação do pesquisador durante a sua vivência no dia a dia da empresa, pois realizando uma avaliação prévia dos documentos disponibilizados pela empresa, constatou-se uma quantidade relevante de informações incompletas por razão da falta de controles.

\section{Etapa 3 - Avaliação dos dados}

Após o período de coleta de dados descrito na etapa anterior, foi realizada uma análise sobre a qualidade das informações coletadas, bem como a importância delas para o desenvolvimento das ações de melhoria. A avaliação dos dados foi suficiente para executar a análise e o planejamento das ações.

\section{Etapa 4 - Análise dos dados}

Com base nos dados coletados nas entrevistas, reuniões, documentos e observação do pesquisador, as informações foram organizadas em quatro grandes áreas da empresa: finanças, recursos humanos, comercial e produção.

A análise dos dados buscou apresentar a visão dos diretores e a do pesquisador, uma vez que este possui participação ativa no projeto. Embora o pesquisador estivesse desenvolvendo uma atividade profissional, as análises foram realizadas de forma imparcial com a empresa.

Como a característica da pesquisa é qualitativa, exploratória e descritiva, além dos dados coletados e analisados, foram utilizados modelos de demonstrativos 
e fórmulas matemáticas financeiras abordadas na revisão de literatura para avaliação financeira da empresa.

A técnica escolhida para a análise dos dados coletados foi a análise de conteúdo validando as informações por meio da técnica de triangulação de diferentes fontes de informação de dados. Segundo Mozzato e Grzybovski (2011, p.734), "[...] a análise de conteúdo tem como objetivo ultrapassar as incertezas e enriquecer a leitura dos dados coletados". Por conseguinte, Bardin (2006) e Mozzato e Grzybovski (2011) recomendam o cuidado com a descrição e execução durante a análise, por mais que sejam mantidas a criatividade e a flexibilidade, pois é uma forma de gerar credibilidade.

\section{Etapa 5 - Plano de ação}

Essa etapa abordou a elaboração do plano de ação com as principais medidas que deveriam ser tomadas para a retomada dos resultados financeiros do negócio. As ações foram formuladas com a observação do pesquisador e sua experiência profissional, informações dos diretores e colaboradores e documentos.

Uma vez que cada empresa tem suas peculiaridades, mesmo estando no mesmo ramo de atividade, as características analisadas, bem como o tipo da pesquisa, o modelo de gestão, a cultura da empresa, entre outros fatores faz com que o plano de ação seja único e exclusivo para a empresa, objeto de estudo.

O plano de ação considerou o critério utilizado para a organização das informações por área da empresa, isto é, ações de melhorias foram propostas para as áreas de finanças, recursos humanos, comercial e produção. A área de finanças foi a base para o planejamento, uma vez que está relacionada ao objetivo desse trabalho, e as demais áreas tiveram suas ações construídas na sequência.

Como ferramenta de controle das ações foi utilizado o aplicativo Trello ${ }^{\circledR}$ que permitiu ao pesquisador envolver todas as pessoas responsáveis com poucas horas de treinamento no acompanhamento das ações com informações em tempo real por celular. O propósito da ferramenta não era apenas controlar as ações, como também o prazo de entrega, a quantidade de ações que cada equipe conseguia concluir e a interação da equipe. 
O aplicativo antes de ser utilizado foi parametrizado pelo pesquisador para funcionar como um fluxo cíclico na implementação de cada ação. O fluxo foi composto por quatro etapas, conforme demonstrado abaixo. A nomenclatura de cada etapa buscou esclarecer de forma clara e objetiva a finalidade daquela etapa, uma vez que os usuários se diferenciavam pelo grau de instrução educacional que possuíam.

1. "O que fazer?": este era o processo inicial no qual o pesquisador registrava a ação com a descrição do problema, como ele seria resolvido, seu prazo de solução, o anexo de algum documento que fosse necessário utilizar e a marcação do rótulo que servia para identificar com cores o status daquela ação (cor verde para ação planejada; amarela para ação em execução; laranja para ação em validação; vermelha para ação ineficaz e azul para concluído). Apenas o pesquisador era responsável por incluir as ações.

2. "Já estamos em execução": após aberta uma ação e iniciada sua execução, o colaborador movia essa ação para essa etapa, significando que a ação já estava sendo resolvida.

3. "Executamos e estamos checando se está ok!": após a resolução do problema que gerou a ação, o pesquisador, juntamente com a equipe, validava se a ação havia sido implementada de forma eficaz. Caso os resultados não fossem satisfatórios, o usuário editava o rótulo daquela ação para a cor vermelha e a ação voltava para a segunda etapa, para ser refeita e logo após validada.

4. "Concluído": ações que foram implementadas com êxito eram movidas para essa etapa e arquivadas.

\section{Etapa 6 - Implementação do plano}

A implementação do plano de ação foi alcançada com os resultados obtidos a partir das informações do demonstrativo de fluxo de caixa publicados no capítulo de Resultados e Discussão desse trabalho.

Durante a fase de implementação, os colaboradores responsáveis pela ação se reuniam semanalmente em reuniões denominadas de comitês, a fim de apresentar ao pesquisador as evoluções das ações e dificuldades enfrentadas na implementação. Em quase todos os comitês algum dos diretores estava presente. 
As mudanças e revisões no plano de ações, quando necessárias, eram realizadas pelo pesquisador.

\section{Etapa 7 - Avaliação}

O processo de avaliação após a implementação das ações tem por objetivo avaliar se as mesmas atingiram ou não o resultado planejado. Essa fase propõe ao pesquisador e às pessoas envolvidas a geração de conhecimento e aprendizado. Caso haja uma ação implementada sem sucesso, o ciclo da pesquisa ação se repete a partir da revisão do planejamento e das ações para que o ciclo se complete como um todo. Sem a etapa de avaliação das ações, independente de sucesso ou falha, a pesquisa ação pode se tornar ineficaz.

\section{Etapa Meta - Monitoramento}

O monitoramento, por ser uma etapa meta, ocorre em todas as etapas da pesquisa ação. Tem por objetivo monitorar, continuamente e em tempo real, como as etapas estão sendo conduzidas, a fim de evitar problemas que possam dificultar o término do ciclo da pesquisa ação.

A etapa meta de monitoramento é realizada pelo próprio pesquisador, proporcionando o controle no desenvolvimento da pesquisa, o conhecimento dos processos e a coleta de novas informações.

\subsection{Modelagem da ferramenta de fluxo de caixa}

A Demonstração dos Fluxos de Caixa (DFC) proposta pela FASB (1987) foi adotada como a ferramenta financeira principal para o desenvolvimento da pesquisa. A escolha por esse modelo foi devido a sua praticidade em operacionalizar o dia a dia da empresa e proporcionar uma análise nas três visões estratégicas: operacional, investimento e financiamento, conforme relatado nos subcapítulos 2.3.3.

Muito embora a instituição de apoio às pequenas empresas brasileiras Sebrae - proponha um demonstrativo simples de fluxo de caixa para a gestão 
financeira, disponível para download no seu portal eletrônico (SEBRAE, 2018d), o modelo não permite ao usuário analisar os resultados por atividades.

De acordo com a revisão teórica, a DFC pode ser obtida por dois métodos: direto e indireto. Para esse trabalho foi utilizado o método direto que permite obter as informações a partir dos lançamentos diários do fluxo de caixa, sendo mais simples e fácil para o usuário com relação ao método indireto que demanda um conhecimento técnico na área contábil.

Foram definidos cinco indicadores financeiros com base nos indicadores propostos no subcapitulo 2.4.6 para o acompanhamento mensal. Com a mesma objetividade do fluxo de caixa, buscou-se a simplicidade nos indicadores, a fim de facilitar o entendimento do produtor e a importância deles para a negócio.

Conforme demonstrado na Figura 11, o primeiro indicador denominado "Estamos rentáveis?" mede a capacidade da empresa de converter suas vendas em caixa. O segundo indicador denominado "Quanto utilizamos para reinvestir?" demonstra o quanto a empresa está utilizando do seu resultado operacional para novos investimentos na operação.

O terceiro indicador denominado "Quanto utilizamos para pagamento de dívidas?" mede a capacidade de pagamento de dívidas com fornecedores, bancos e outros a partir do resulto do fluxo operacional. O quarto indicador denominado "Qual a nossa geração de caixa (aumento de saldo)?" mede o desempenho da empresa em gerar caixa com relação a receitas para serem investidos futuramente em capital de giro e novos investimentos.

Por final, o quinto indicador denominado de "Saldo mínimo de caixa" demonstra o quanto a empresa possui de disponibilidades com relação ao saldo mínimo dimensionado para a operação. Esse indicador foi definido com base no grau de importância detalhada no subcapitulo 2.4.5.

A empresa não possuía fluxo de caixa e tampouco o controle das receitas e despesas de uma forma organizada e segura. Assim, em uma reunião com a diretoria, juntamente com o pesquisador e o colaborador responsável pela área financeira, foi elaborado um plano com três etapas para modelar a ferramenta descritas a seguir:

1. Plano de contas: com base na natureza das receitas e despesas da empresa foi elaborada uma estrutura de contas que seria utilizada para classificar as entradas e saídas do fluxo de caixa. O plano de contas buscou ser intuitivo 
com a nomenclatura das contas e reduzido na quantidade de contas, a fim de facilitar o registro das receitas e despesas e a análise da Demonstração dos Fluxos de Caixa para o usuário, conforme demonstrado no Quadro 14:

Quadro 14 - Plano de contas implantado na empresa

\begin{tabular}{|c|c|}
\hline ENTRADAS & DESCRIÇÃO \\
\hline Receita com venda de ovos & Entradas obtidas com vendas de ovos \\
\hline Receita com venda de suínos & Entradas obtidas com vendas de suínos \\
\hline Outras receitas & $\begin{array}{l}\text { Entradas obtidas com vendas de esterco, descarte de aves, } \\
\text { sucatas, resíduos da fábrica de ração }\end{array}$ \\
\hline Renda de aplicação financeira & Entradas obtidas com investimentos financeiros \\
\hline Entrada de empréstimos & Entradas obtidas com empréstimos de terceiros e bancários \\
\hline Desconto de duplicatas & Entradas obtidas com antecipação de recebíveis a prazo \\
\hline \multicolumn{2}{|l|}{ SAÍDAS } \\
\hline Impostos sob vendas (Funrural) & Saídas relacionadas a impostos incidentes na venda \\
\hline Imposto de renda sob resultado & $\begin{array}{l}\text { Saídas relacionadas a gasto com imposto de renda do período } \\
\text { anterior }\end{array}$ \\
\hline Ovos para revenda/conservas & $\begin{array}{l}\text { Saídas relacionadas a compras de ovos para revenda e materiais } \\
\text { para conserva de ovos }\end{array}$ \\
\hline Aquisição de Pintinhas/Frangas & Saídas relacionadas a aquisição de aves para a produção \\
\hline Embalagens & Saídas relacionadas a embalagens para produto acabado \\
\hline Energia elétrica & Saídas relacionadas a energia elétrica e gerador \\
\hline Insumos - Farelo de soja & Saídas relacionadas a farelo de soja para ração \\
\hline Insumos - Milho & Saídas relacionadas a milho para ração \\
\hline $\begin{array}{l}\text { Insumos - Outros insumos para } \\
\text { ração }\end{array}$ & $\begin{array}{l}\text { Saídas relacionadas a Premix, calcário, sal e outros insumos para } \\
\text { a ração }\end{array}$ \\
\hline Despesas com agricultura & Saídas relacionadas ao plantio de milho \\
\hline $\begin{array}{l}\text { Vacinas/Medicamentos/ } \\
\text { Desinfecção }\end{array}$ & $\begin{array}{l}\text { Saídas relacionadas a vacinas, medicamentos e desinfecção das } \\
\text { aves }\end{array}$ \\
\hline $\begin{array}{l}\text { Despesas com vendas } \\
\text { (comissões, refeições, outros) }\end{array}$ & $\begin{array}{l}\text { Saídas relacionadas a comissão e gastos de viagens da equipe } \\
\text { comercial }\end{array}$ \\
\hline Despesas bancárias & Saídas relacionadas a tarifas bancárias \\
\hline Manutenção predial & Saídas relacionadas a reparos e reformas dos galpões \\
\hline Materiais de cozinha e limpeza & Saídas relacionadas a materiais de cozinha e limpeza \\
\hline Material de escritório & $\begin{array}{l}\text { Saídas relacionadas a gastos com papelaria e materiais de } \\
\text { escritório }\end{array}$ \\
\hline Serviços de terceiros & $\begin{array}{l}\text { Saídas relacionadas a prestadores de serviços jurídico, contábil, } \\
\text { segurança do trabalho, veterinário e outros }\end{array}$ \\
\hline Telefonia/Internet & Saídas relacionadas a gastos com telefonia fixa, móvel e internet \\
\hline $\begin{array}{l}\text { Veículos } \\
\text { (combustível/manutenção) }\end{array}$ & $\begin{array}{l}\text { Saídas relacionadas a combustível e manutenção dos veículos e } \\
\text { caminhões }\end{array}$ \\
\hline Logística (pedágios e outros) & Saídas relacionadas a entrega dos produtos em clientes \\
\hline $\begin{array}{l}\text { Manutenção das instalações e } \\
\text { equipamentos de produção }\end{array}$ & $\begin{array}{l}\text { Saídas relacionadas a reparos das instalações e equipamentos } \\
\text { da produção }\end{array}$ \\
\hline Salários & Saídas relacionadas a salários mensais, férias e décimo terceiro \\
\hline
\end{tabular}


conclusão

\begin{tabular}{|l|l|}
\hline Encargos & Saídas relacionadas a INSS, FGTS, IRRF, sindicatos e outros \\
\hline Benefícios & Saídas relacionadas a benefícios concedidos aos funcionários \\
\hline Rescisões trabalhistas & Saídas relacionadas a desligamento de funcionários \\
\hline Passivos trabalhistas & Saídas relacionadas a demandas trabalhistas na esfera judicial \\
\hline Renegociação de dívidas & Saídas relacionadas a contas não pagas e vencidas acima de 120 dias \\
\hline Retirada dos sócios & Saídas relacionadas a salários dos sócios e retiradas de resultados \\
\hline Publicidade & Saídas relacionadas a divulgação dos produtos e marcas \\
\hline $\begin{array}{l}\text { Outras despesas } \\
\text { operacionais }\end{array}$ & $\begin{array}{l}\text { Saídas relacionadas a compra de materiais que não se classificam nas } \\
\text { demais contas }\end{array}$ \\
\hline Pagamento de empréstimo & $\begin{array}{l}\text { Saídas relacionadas a pagamento de empréstimo de terceiros e } \\
\text { bancários }\end{array}$ \\
\hline Investimentos na operação & Saídas relacionadas a investimentos para a melhoria da operação \\
\hline Juros Passivo & $\begin{array}{l}\text { Saídas relacionadas a juros por atraso de pagamentos e descontos de } \\
\text { duplicatas }\end{array}$ \\
\hline $\begin{array}{l}\text { Devolução de duplicatas } \\
\text { não pagas }\end{array}$ & $\begin{array}{l}\text { Saídas relacionadas a devolução de duplicata descontada que não foi } \\
\text { liquidada pelo cliente }\end{array}$ \\
\hline Empréstimo para terceiros & $\begin{array}{l}\text { Saídas relacionadas a empréstimo de dinheiro para terceiros, sócios e } \\
\text { funcionários }\end{array}$ \\
\hline Transferência entre contas & Transação entre contas bancárias \\
\hline
\end{tabular}

Fonte: Própria autoria.

2. Agrupamento das contas: após definido o plano de contas, as contas foram agrupadas em grupos financeiros: operacional, investimento e financiamento, conforme modelo demonstrado no capítulo 2.4.1. Além desse agrupamento, as contas de despesas operacionais também foram agrupadas em subgrupos, denominados: Impostos sob Vendas; Custos de Produção; Logística \& Distribuição; Comercial; Ocupação \& Apoio e Folha de Pagamento.

Quadro 15 - Plano de contas da empresa com agrupamento

\begin{tabular}{|l|c|c|}
\hline ENTRADAS & GRUPO FINANCEIRO & $\begin{array}{c}\text { SUB GRUPO } \\
\text { OPERACIONAL }\end{array}$ \\
\hline Receita com venda de ovos & Operacional & - \\
\hline Receita com venda de suínos & Operacional & - \\
\hline Outras receitas & Operacional & - \\
\hline Renda de aplicação financeira & Investimento & - \\
\hline Entrada de empréstimos & Financiamento & - \\
\hline Desconto de duplicatas & Financiamento & - \\
\hline
\end{tabular}




\begin{tabular}{|c|c|c|}
\hline SAÍDAS & $\begin{array}{c}\text { GRUPO } \\
\text { FINANCEIRO }\end{array}$ & $\begin{array}{l}\text { SUB GRUPO } \\
\text { OPERACIONAL }\end{array}$ \\
\hline Impostos sob vendas (Funrural) & Operacional & $\begin{array}{l}\text { Impostos s/vendas e } \\
\text { resultados }\end{array}$ \\
\hline Imposto de renda sob resultado & Operacional & $\begin{array}{l}\text { Impostos s/vendas e } \\
\text { resultados }\end{array}$ \\
\hline Ovos para revenda/conservas & Operacional & Custos de Produção \\
\hline Aquisição de Pintinhas/Frangas & Investimento & - \\
\hline Embalagens & Operacional & Custos de Produção \\
\hline Energia elétrica & Operacional & Custos de Produção \\
\hline Insumos - Farelo de soja & Operacional & Custos de Produção \\
\hline Insumos - Milho & Operacional & Custos de Produção \\
\hline Insumos - Outros insumos para ração & Operacional & Custos de Produção \\
\hline Despesas com agricultura & Operacional & Custos de Produção \\
\hline Vacinas/Medicamentos/Desinfecção & Operacional & Custos de Produção \\
\hline $\begin{array}{l}\text { Despesas com vendas (comissões, refeições, } \\
\text { outros) }\end{array}$ & Operacional & Comercial \\
\hline Despesas bancárias & Operacional & Ocupação \& Apoio \\
\hline Manutenção predial & Operacional & Ocupação \& Apoio \\
\hline Materiais de cozinha e limpeza & Operacional & Ocupação \& Apoio \\
\hline Material de escritório & Operacional & Ocupação \& Apoio \\
\hline Serviços de terceiros & Operacional & Ocupação \& Apoio \\
\hline Telefonia/Internet & Operacional & Ocupação \& Apoio \\
\hline Veículos (combustível/manutenção) & Operacional & Logística \& Distribuição \\
\hline Logística (pedágios e outros) & Operacional & Logística \& Distribuição \\
\hline $\begin{array}{l}\text { Manutenção das instalações e equipamentos de } \\
\text { produção }\end{array}$ & Operacional & Custos de Produção \\
\hline Salários & Operacional & Folha de Pagamento \\
\hline Encargos & Operacional & Folha de Pagamento \\
\hline Benefícios & Operacional & Folha de Pagamento \\
\hline Rescisões trabalhistas & Operacional & Folha de Pagamento \\
\hline Passivos trabalhistas & Operacional & Folha de Pagamento \\
\hline Renegociação de dívidas & Financiamento & - \\
\hline Retirada dos sócios & Operacional & Folha de Pagamento \\
\hline Publicidade & Operacional & Comercial \\
\hline Outras despesas operacionais & Operacional & Ocupação \& Apoio \\
\hline Pagamento de empréstimo & Financiamento & - \\
\hline Investimentos na operação & Investimento & - \\
\hline Juros Passivo & Financiamento & - \\
\hline Devolução de duplicatas não pagas & Financiamento & - \\
\hline Empréstimo para terceiros & Financiamento & - \\
\hline Transferência entre contas & - & - \\
\hline
\end{tabular}

Fonte: Própria autoria. 
3. Parametrização da ferramenta: a ferramenta foi desenvolvida em planilha eletrônica do Microsoft Exce ${ }^{\circledR}$ composta por duas planilhas: a primeira para os lançamentos das entradas e saídas do fluxo de caixa, na qual estavam as informações sobre os dados dos lançamentos, a conta de receita ou despesa que seria empenhada, os saldos bancários e o saldo previsto considerando 0 saldo bancário atual com as projeções e os compromissos assumidos para os dias seguintes. A segunda planilha contemplava o Demonstrativo dos Fluxos de Caixa, isto é, um resumo das operações efetivamente realizadas no fluxo de caixa, conforme demonstrado na Figura 11.

Durante a reunião de modelagem do fluxo de caixa, o pesquisador realizou treinamento com os participantes por meio de dinâmicas que permitiram rapidamente a compreensão e distinção das contas de receitas e despesas em operacionais, investimento e financiamento.

A dinâmica utilizou explanações lúdicas do conceito teórico, para aproximar a teoria com as novas atividades de execução dos responsáveis. A ferramenta ficou compartilhada com a equipe por meio do aplicativo Dropbox ${ }^{\circledR}$, que permitia a visualização, a gestão e a interação do pesquisador com o projeto em períodos ausentes na empresa. 
Figura 10 - Tela de lançamento de entradas e saídas do fluxo de caixa implantado na empresa

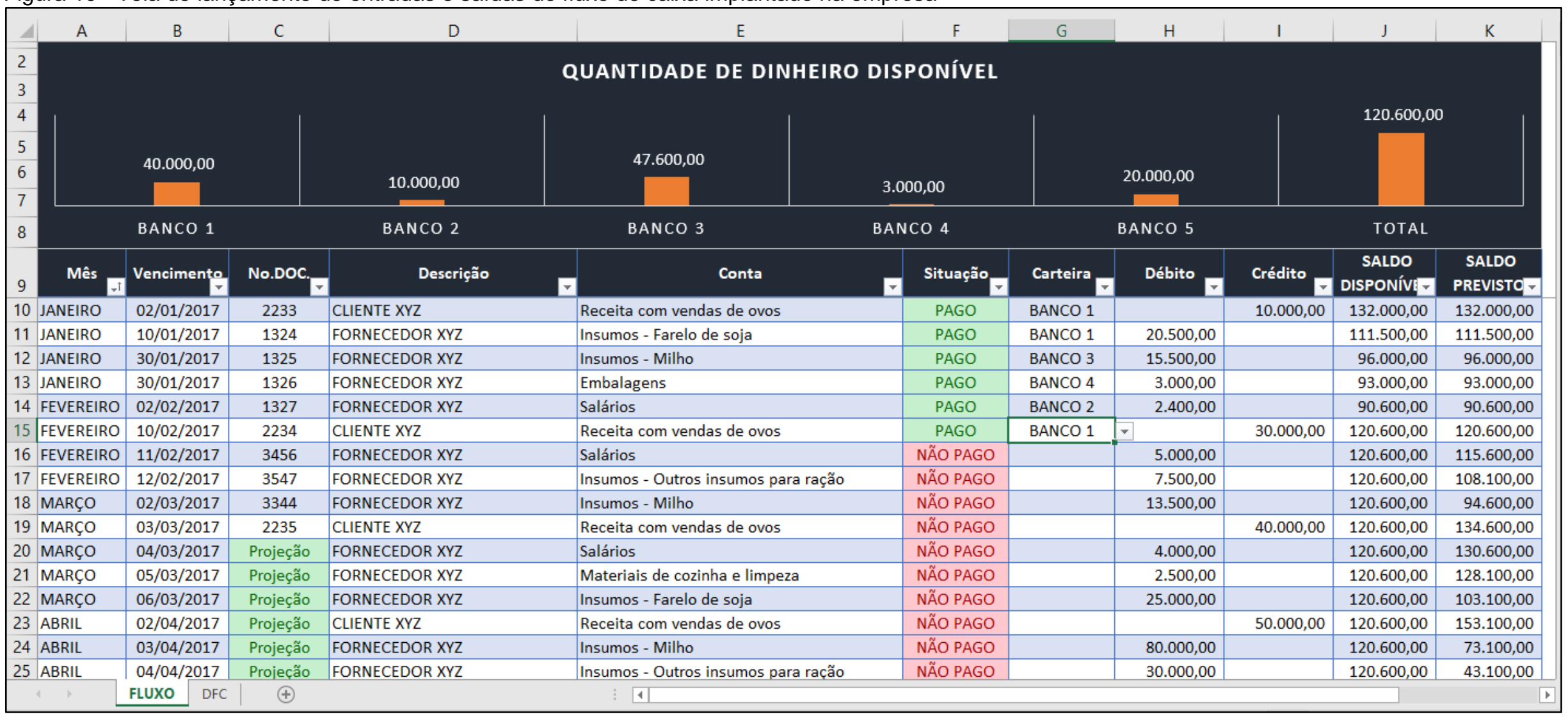

Fonte: Própria autoria. 
Figura 11 - Demonstrativo dos fluxos de caixa implantado na empresa

\begin{tabular}{|c|c|c|c|c|c|c|c|c|c|c|c|c|c|}
\hline \multicolumn{14}{|c|}{ DEMONSTRATIVO DOS FLUXOS DE CAIXA } \\
\hline & JAN & FEV & MAR & ABR & MAI & JUN & JuL & AGO & SET & out & Nov & DEZ & ACUMULAdo \\
\hline \multicolumn{14}{|l|}{ (+) RECEITAS OPERACIONAIS } \\
\hline Receita com venda de ovos & - & - & - & - & - & - & - & - & - & - & - & 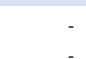 & \\
\hline $\begin{array}{l}\text { Receita com venda de suínos } \\
\text { Outras receitas }\end{array}$ & - & 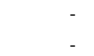 & & & & - & & & - & - & & & \\
\hline (-) DESPESAS OPERACIONAIS & - & . & . & - & - & - & - & - & . & - & - & - & \\
\hline Impostos s/vendas e resultados & - & & - & - & & - & & - & - & - & - & & \\
\hline Custos de produção & - & - & - & - & . & - & - & - & - & - & - & - & \\
\hline Logística \& Distrtibuição & - & - & - & - & - & - & - & - & - & - & - & - & \\
\hline Folha de pagamento & - & - & - & - & . & - & - & - & - & - & - & - & \\
\hline Ocupação \& Apoio & - & - & & - & - & - & & - & - & - & & - & \\
\hline Comercial & - & - & - & - & - & - & - & - & - & - & - & & \\
\hline (E) RESULTADO OPERACIONAL & - & - & - & - & - & - & - & - & - & - & - & - & \\
\hline (+) Renda Aplicação Financeira & - & $\cdot$ & & & - & $\cdot$ & & & - & & & & \\
\hline $\begin{array}{l}\text { (-) Aquisição de Pintinhas/Matrizes/Frangas } \\
(-) \text { Investimentos na operacão }\end{array}$ & & & & & & & & & & & & & \\
\hline $\begin{array}{l}(-) \text { Investimentos na operaçăo } \\
\text { (E) RESULTADO DE INVESTIMENTO }\end{array}$ & . & . & . & . & . & . & . & . & . & . & . & . & \\
\hline (+) Entrada de Empréstimos & & & & & & & - & & & & & & \\
\hline (+) Desconto de duplicatas & - & - & & & - & - & & & - & - & & & \\
\hline (-) Devoluçăo de duplicatas não pagas & $\cdot$ & $\cdot$ & & & - & $\cdot$ & & & $\cdot$ & $\cdot$ & & & \\
\hline (-) Pagamento de empréstimos & $\cdot$ & $\cdot$ & & & $\cdot$ & $\cdot$ & & & $\cdot$ & $\cdot$ & & & \\
\hline (-) Renegociação de dividas & $\cdot$ & $\cdot$ & & & - & $\cdot$ & & & $\cdot$ & $\cdot$ & & & \\
\hline (-) Juros Passivo & & & & & & & & & & & & & \\
\hline (-) Empréstimo para terceiros & & & - & - & & & - & & & & & & \\
\hline (E) RESULTADO DE FINANCIAMENTOS & - & - & - & - & - & - & - & - & - & - & - & - & \\
\hline \multicolumn{14}{|l|}{ (E) RESULTADO FINAL (GERAÇ̄O DE CAIXA) } \\
\hline \multirow{2}{*}{\multicolumn{14}{|c|}{$\begin{array}{l}\text { SALDO INIIIAL DE DINHEIRO } \\
\text { SALDO FINAL DE DINHEIRO }\end{array}$}} \\
\hline & & & & & & & & & & & & & \\
\hline \multicolumn{14}{|l|}{$\begin{array}{l}\text { CONTAS NÃO PAGAS } \\
\text { CONTAS A RECEBER }\end{array}$} \\
\hline \multicolumn{14}{|l|}{$\begin{array}{l}\text { CONOASASARECEEERR } \\
\text { PROJA̧O DE SALO DE DINHEIRO }\end{array}$} \\
\hline \multicolumn{14}{|c|}{ INDICADORES FINANCEIROS } \\
\hline Estamos rentáveis? & $0,0 \%$ & & $0,0 \%$ & & & & $0,0 \%$ & $0,0 \%$ & & $0,0 \%$ & $0,0 \%$ & & $0,0 \%$ \\
\hline Quanto utilizamos para reinvestir? & $0,0 \%$ & $0,0 \%$ & $0,0 \%$ & $0,0 \%$ & $0,0 \%$ & $0,0 \%$ & $0,0 \%$ & $0,0 \%$ & $0,0 \%$ & $0,0 \%$ & $0,0 \%$ & $0,0 \%$ & $0,0 \%$ \\
\hline Quanto utilizamos para pagamento de dividas? & $0,0 \%$ & $0,0 \%$ & $0,0 \%$ & $0,0 \%$ & $0,0 \%$ & $0,0 \%$ & $0,0 \%$ & $0,0 \%$ & $0,0 \%$ & $0,0 \%$ & $0,0 \%$ & $0,0 \%$ & $0,0 \%$ \\
\hline Qual a nossa geração de caixa (aumento de saldo)? & $0,0 \%$ & $0,0 \%$ & $0,0 \%$ & $0,0 \%$ & $0,0 \%$ & $0,0 \%$ & $0,0 \%$ & $0,0 \%$ & $0,0 \%$ & $0,0 \%$ & $0,0 \%$ & $0,0 \%$ & $0,0 \%$ \\
\hline Saldo mínimo de caixa & 0,00 & 0,00 & 0,00 & 0,00 & 0,00 & 0,00 & 0,00 & 0,00 & 0,00 & 0,00 & 0,00 & 0,00 & 0,00 \\
\hline
\end{tabular}

Fonte: Própria autoria. 
3.3 Aspectos éticos da pesquisa

A pesquisa foi aprovada pelo Comitê de Ética em Pesquisa com Seres Humanos da Faculdade de Zootecnia e Engenharia de Alimentos da Universidade de São Paulo, com o Certificado de Apresentação para Apreciação Ética (CAAE) no 13310919.6.0000.5422 e número do parecer 3.326.601. O Termo de Consentimento Livre encontra-se como apêndice nesse trabalho. 


\section{RESULTADOS}

De acordo com a metodologia de pesquisa adotada - pesquisa-ação -, bem como da participação do autor como profissional de uma empresa de consultoria e pesquisador neste projeto, buscou-se com sua experiência em gestão de pequenas e médias empresas estruturar um modelo de gestão de fluxo de caixa para a tomada de decisão, com a preocupação de que tal modelo pudesse ser simples e fácil para ser aplicado em uma empresa rural.

Conforme relatado anteriormente, a empresa não possuía um fluxo de caixa para controle das entradas e saídas de dinheiro que aconteciam todos os dias. Dessa forma, o proprietário-gestor não possuía informações seguras e organizadas para apoiá-lo em suas tomadas de decisões, tampouco possuía dados que sinalizassem as principais operações da empresa para dar-lhe a certeza de que os valores finais de saldo, quando somados, conferiam exatamente em centavos de reais com os saldos das contas bancárias e de caixa.

Além da falta de um instrumento de gestão de fluxo de caixa, a empresa enfrentava uma intensa dificuldade financeira pela falta de capital de giro, o que em poucos meses poderia causar a falência do negócio.

Com o foco no objetivo principal em propor um modelo de fluxo de caixa para a tomada de decisão, o autor participou ativamente durante o primeiro e segundo semestres de 2017 na empresa ajudando o proprietário-gestor a tomar decisões estratégicas que precisavam ser implementadas rapidamente.

Assim, o apoio do autor com os modelos e técnicas existentes na literatura para o embasamento dessa pesquisa foi muito importante, pois possibilitou analisar a empresa empiricamente e avaliar a possibilidade de gerir a empresa apenas com o fluxo de caixa.

4.1 Os resultados sem o uso da ferramenta de fluxo de caixa

A empresa, objeto de estudo dessa pesquisa, é uma granja produtora de ovos de postura comercial, localizada na região de Pirassununga, interior do Estado de São Paulo. De acordo com o critério de classificação do porte de empresa emitido pelo Banco Central do Brasil e BNDES (BCB, 2018; BNDES, 2018) com base no faturamento anual, a empresa é considerada de médio porte com um faturamento 
anual em torno de $\mathrm{R} \$ 6,0$ milhões. Por questões éticas e a pedido da empresa, a identificação comercial foi preservada.

A empresa iniciou suas atividades em 1970 com uma pequena produção de ovos produzidos por 1.500 aves. Com poucos recursos e sem experiência na produção de ovos, o fundador da empresa iniciou seus primeiros passos na construção de um negócio para complementar a renda familiar. Pai de três filhos e com pouco estudo, o fundador incentivou seu filho mais velho a trabalhar junto a ele no pequeno negócio.

Em 1987, seu filho assumiu o papel de proprietário-gestor da empresa com o objetivo de fazê-la crescer. Sua estratégia foi posicionar os produtos nas gôndolas de supermercados e em pequenas mercearias. Prezando pela qualidade dos ovos e o bom atendimento que fornecia aos clientes, após alguns anos a granja começou a crescer com a construção de novos galpões e da sala de ovos para o aumento da produção. O patriarca, ainda ao lado do filho, manteve-se resistente à visão do filho em expandir o pequeno negócio, mas a força empreendedora do filho conseguiu suplantar a resistência do pai.

Entre os anos de 1990 e 2000, a granja conquistou o mercado varejista compondo sua carteira de clientes com grandes redes de supermercados. Com isso, sua capacidade de produção cresceu de 1.500 aves para 120.000 aves alojadas. Aproveitando a demanda do mercado de ovos e os preços inflacionados no início desse período, o filho decidiu diversificar a produção da propriedade da família construindo uma granja de suínos.

Com um investimento em mais de um milhão de reais em instalações com capacidade para alojar 400 matrizes e 4.500 animais na fase de terminação, a granja de suínos possuía estrutura para todas as etapas de produção, desde a maternidade, creche, crescimento e terminação. Nesse período, o proprietário-gestor assumiu o novo desafio da empresa de dividir sua expertise de produção de ovos com uma produção em escala de suínos. Com vivência em produção agrícola, o novo desafio para o filho do patriarca era o mesmo experimentado com a expansão da produção de ovos.

Durante todo esse período, o proprietário-gestor não controlava suas finanças com rigor. As decisões eram tomadas de acordo com a sua intuição e a rentabilidade medida com a capacidade de construção de galpões, silos, compra de novos maquinários, caminhões, aquisição de bens pessoais e outros ativos que 
imobilizavam o capital gerado pelas atividades. Contudo, isso não o preocupava, pois havia folga financeira no caixa da empresa.

Entretanto, a economia do país passou a caminhar de encontro a suas expectativas, pois, a partir do ano de 2006, a empresa começou a enfrentar dificuldades financeiras, sendo estas vistas pelo proprietário-gestor, de acordo com sua experiência, como algo controlável e contornável. Porém, o mercado estava em mudanças e novos concorrentes chegaram para a produção de ovos.

Sua dificuldade financeira começou a se agravar após 2006 pelo fato de a estrutura de produção requerer manutenções e ainda pela necessidade de novos investimentos na renovação de plantel de suínos e aves. O resultado do negócio que crescia com os "bons ventos" da economia não era mais suficiente para manter a operação em funcionamento. Com crédito no mercado e um histórico de sucesso, a falta de dinheiro passou a ser suprida por fornecedores, bancos e cooperativas que se mantiveram durante muito tempo ao lado do produtor.

Porém, após alguns anos, os credores, ao perceberem a dificuldade em receber o capital emprestado para a empresa, bloquearam o crédito para novas solicitações e, a partir deste momento, a empresa se dispôs de uma parte da área da propriedade para captar recursos, e pessoas próximas e parentes passaram a ser agentes financiadores do proprietário-gestor.

Nesse período, sua esposa, que não trabalhava na empresa até então, começou a ajudá-lo nas principais atividades gerenciais. Sentindo-se o responsável pela construção do sucesso da empresa, o filho do patriarca demonstrava um perfil de centralização de poder com as pessoas ao seu redor. Sua voz prevalecia na comunicação com os funcionários, de modo que pouco os ouvia, e ele passou a utilizar a mesma postura com sua esposa. 
Figura 12 - Organograma antes do uso do fluxo de caixa

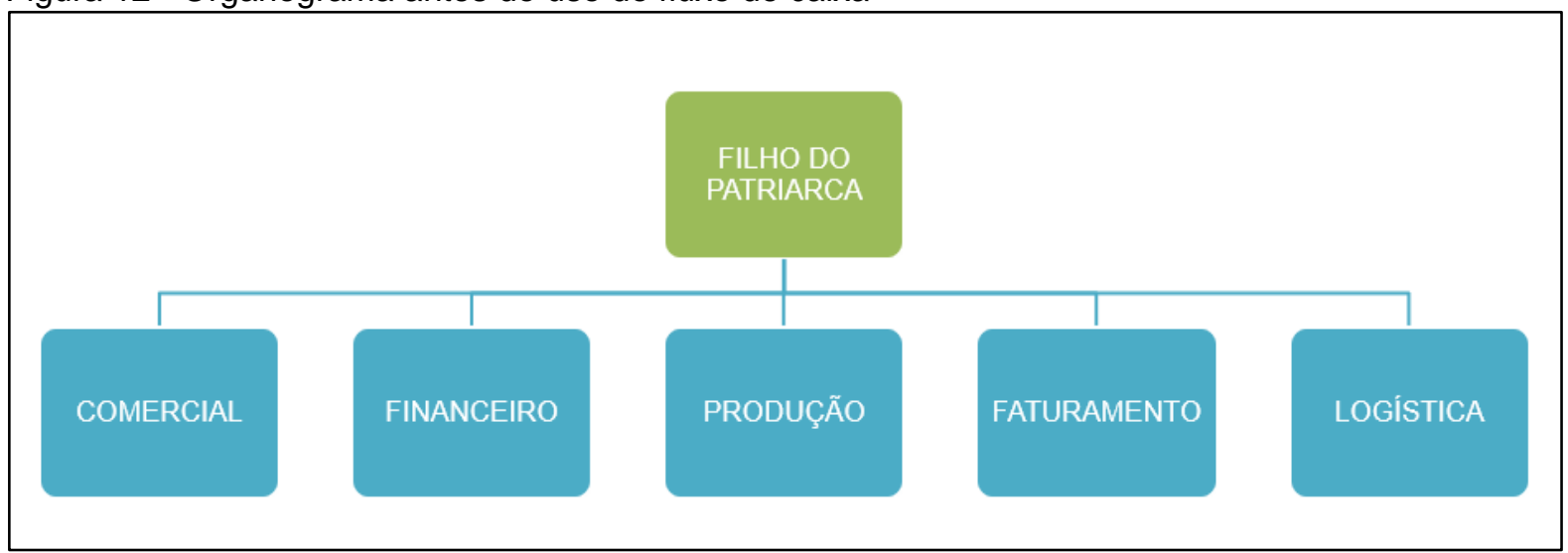

Fonte: Própria autoria.

Mesmo com as dificuldades em continuar com a operação funcionando, o proprietário-gestor manteve sua força e ânimo em resolver a situação e colocar a empresa novamente no patamar anterior. Seu otimismo e persistência não o deixava desanimar, ainda que enfrentasse desequilíbrios emocionais durante esse período.

Em 2016, a empresa contava com 40 funcionários e sem capital para manter a operação funcionando. Em virtude da má administração, os salários dos funcionários estavam atrasados. Aliado a isso, os preços de milho e do farelo de soja estavam elevados, o que aumentava ainda mais o risco iminente de falência. Nesse momento, o proprietário-gestor buscou ajuda de especialistas em gestão financeira. Para ele, o apoio consistia em identificar erros e falhas que ele não conseguia visualizar nem solucionar por estar vivenciando o problema. Relatado esse histórico, foi identificada a resposta da primeira pergunta sobre quais os motivos que levaram a empresa a buscar um apoio externo para a gestão.

Com baixa credibilidade no mercado e clientes migrando para a concorrência, as pessoas mais próximas não mais acreditavam no negócio e no sucesso do proprietário-gestor e com isso restringiram o crédito. As empresas de fomento que antes realizavam a antecipação de duplicatas a prazo reduziram o limite de crédito por precaução e, com essas mudanças de disponibilidade de dinheiro, a dificuldade do proprietário-gestor em gerir o dia a dia da empresa se agravou grandemente.

A empresa não tinha mais a produção de ovos de acordo com sua capacidade produtiva, pois, devido às dificuldades financeiras, 0 produtor interrompeu a recria das aves e o plantel foi reduzido de 120.000 aves para 60.000 aves. A produção de suínos operava até a etapa de creche, quando os animais 
atingiam 22 quilos e eram vendidos para outro produtor que continuava o processo de crescimento e terminação até atingir o peso de 100 quilos para abate. As instalações de crescimento e terminação estavam paradas por falta de capital. Os animais vendidos eram pagos por meio de permuta com milho à granel, devido à restrição de crédito que o produtor estava com os fornecedores de insumos na região.

Mediante toda essa dificuldade, o maior desafio do proprietário-gestor era manter os animais alimentados, pois nos últimos meses isso não vinha ocorrendo todos os dias. Para ele, as decisões de manter a empresa sempre em expansão não foram planejadas de acordo com as condições de caixa, e o capital que a empresa possuía não foi administrado corretamente, o que responde à segunda questão sobre quais as principais decisões tomadas que contribuíram para o cenário atual. Assim, tanto para ele quanto para sua esposa, o cenário promissor e reversivo viria com a retomada das etapas de crescimento e terminação de leitões, pois vendê-los com o peso de abate traria maior rentabilidade do que vendê-los na etapa de creche.

Utilizando da técnica de coleta de dados por observação e de levantamento das informações com os funcionários e diretores, foi elaborado um mapa de diagnóstico com os principais problemas da empresa, conforme demonstrado no Quadro 16. 
Quadro 16 - Mapa de diagnóstico dos principais problemas da empresa

\begin{tabular}{|c|c|c|}
\hline PROBLEMA & SITUAÇÃO & MOTIVO \\
\hline \multirow{6}{*}{ PRODUÇÃO DE OVOS } & Redução de 120.000 aves para 60.000 aves, gerando capacidade ociosa & Recursos financeiros \\
\hline & Falta frequente de ração para a alimentação das aves & Recursos financeiros \\
\hline & Aves com baixa produtividade e idade média de 120 semanas & Recursos financeiros \\
\hline & Baixo gerenciamento de manejo & Recursos humanos \\
\hline & Alto índice de ovos com casca fina e trincados & Recursos financeiros \\
\hline & Falta de insumos para embalagens dos produtos & Recursos financeiros \\
\hline \multirow{5}{*}{ PRODUÇÃO DE SUÍNOS } & Baixo gerenciamento de manejo e de acompanhamento técnico & Recursos humanos \\
\hline & Índice elevado de mortalidade & Recursos humanos \\
\hline & Utilização de marrãs para recompor a granja com baixa produtividade & Recursos financeiros \\
\hline & Instalações e equipamentos em condições precárias e com capacidade ociosa & Recursos financeiros \\
\hline & Falta frequente de ração para a alimentação dos animais & Recursos financeiros \\
\hline \multirow{4}{*}{ RECURSOS HUMANOS } & Alta rotatividade e absenteísmo & Recursos financeiros \\
\hline & Salários e outros benefícios atrasados & Recursos financeiros \\
\hline & Mão de obra sem capacitação & Recursos financeiros \\
\hline & Baixa motivação de toda a equipe & Recursos financeiros \\
\hline \multirow{3}{*}{ COMERCIAL } & Clientes migrando para a concorrência & Qualidade \\
\hline & Alto índice de trocas e devolução de mercadorias & Qualidade \\
\hline & Atendimento comercial frágil & Recursos humanos \\
\hline \multirow{3}{*}{ FINANCEIRO } & Software de controle interno (ERP) ineficaz & Recursos financeiros \\
\hline & Controles financeiros e de fluxo de caixa ineficientes & Recursos humanos \\
\hline & Equipe despreparada e com pouco conhecimento das atividades financeiras & Recursos humanos \\
\hline
\end{tabular}


De acordo com as informações demonstradas no Quadro 16, foi realizada uma análise financeira da viabilidade das duas unidades de operação da empresa: a produção de ovos e a produção de suínos. Devido à tradição na produção de ovos, essa unidade de negócio era a que mais gerava receita para a empresa. Com participação de cerca de $73,0 \%$ nas receitas totais, a produção de ovos, mesmo que ineficiente por questões principalmente de qualidade e idade do plantel, garantia o faturamento da empresa com o mercado conquistado.

Em um raio de até cem quilômetros da sede da empresa, a marca dos ovos ainda era conhecida e lembrada pelo período de sucesso. Esse reconhecimento do mercado devia-se a um investimento massivo de capital na divulgação da marca realizado nos anos 2000. Através dos meios de comunicação televisivos e de rádios com abrangência regional, os ovos da granja passaram a ser lembrados através de um slogan e de uma vinheta musical que atraía as crianças. O sucesso com a publicidade foi tanta, que as mães ligavam na empresa para deixar os filhos escutando a vinheta que tocava nos ramais de telefone.

Mas o sucesso da marca não garantiu as vendas para as grandes redes de supermercados. Essas passaram a migrar para a concorrência devido à falta de qualidade e atendimento. Com a perda de grandes clientes, a empresa começou a focar sua força comercial em pequenos revendedores de porta a porta, pequenos supermercados, restaurantes, mercearias e padarias que não exigiam tanta qualidade quanto os grandes varejistas.

Portanto, a operação de ovos necessitava de um incremento de capital para a renovação do plantel, compra de insumos e capacitação da mão de obra, pois assim seria possível garantir a qualidade do produto no mercado e reestabelecer os resultados financeiros da empresa em curto prazo.

A operação de suínos correspondia a cerca de $27,0 \%$ das receitas totais da empresa e as vendas eram concentradas em dois pequenos produtores de suínos que compravam os animais para a engorda e processamento da carne. $O$ pesquisador acompanhou por vários dias as atividades dos funcionários que trabalhavam no setor para o levantamento das informações.

A produtividade era muito baixa por vários fatores, entre eles, a falta de domínio no conhecimento técnico de manejo, instalações não adequadas e plantel de matrizes de marrãs. Esses fatores contribuíam para o alto índice de mortalidade de recém-nascidos. 
Ao modelar um fluxo de caixa com os gastos históricos juntamente com a diretoria, a operação de suínos apontava para um resultado deficitário. O custo mensal para manter a granja era de $\mathrm{R} \$ 166.689,63$ para 1.300 animais alojados com gastos relacionados a ração, mão de obra e outros materiais (medicamentos, vacinas, inseminação e outros), conforme demonstrado no Quadro 17. A receita média da operação era em torno de $\mathrm{R} \$ 120.000,00$ reais por mês. Sendo assim o resultado mensal ficava deficitário em torno de $R \$ 47.000,00$, correspondendo a um montante acumulado de $\mathrm{R} \$ 564.000,00$ por ano.

Quadro 17 - Custo mensal da unidade suína

\begin{tabular}{|l|c|rr|rr|rr|rr|}
\hline \multicolumn{1}{|c|}{ CICLO } & \multirow{2}{*}{ QTD. ANIMAIS } & \multicolumn{2}{c|}{ RAÇÃO } & \multicolumn{2}{c|}{ MÃO DE OBRA } & \multicolumn{2}{c|}{$\begin{array}{c}\text { OUTROS } \\
\text { MATERIAIS }\end{array}$} & \multicolumn{1}{c|}{ TOTAL } \\
\hline Gestação & 265 & $\mathrm{R} \$$ & $22.322,33$ & $\mathrm{R} \$$ & $6.000,00$ & $\mathrm{R} \$$ & $2.493,75$ & $\mathrm{R} \$$ & $30.816,08$ \\
\hline Maternidade & 35 & $\mathrm{R} \$$ & $7.534,80$ & $\mathrm{R} \$$ & $3.000,00$ & $\mathrm{R} \$$ & 218,75 & $\mathrm{R} \$$ & $10.753,55$ \\
\hline Creche & 400 & $\mathrm{R} \$$ & $18.630,00$ & $\mathrm{R} \$$ & $3.000,00$ & $\mathrm{R} \$$ & $1.400,00$ & $\mathrm{R} \$$ & $23.030,00$ \\
\hline Terminação & 600 & $\mathrm{R} \$$ & $97.290,00$ & $\mathrm{R} \$$ & $3.000,00$ & $\mathrm{R} \$$ & $1.800,00$ & $\mathrm{R} \$$ & $102.090,00$ \\
\hline TOTAL & $\mathbf{1 . 3 0 0}$ & $\mathbf{R} \$ \mathbf{1 4 5 . 7 7 7 , 1 3}$ & $\mathbf{R} \$$ & $\mathbf{1 5 . 0 0 0 , 0 0}$ & $\mathbf{R} \$$ & $\mathbf{5 . 9 1 2 , 5 0}$ & $\mathbf{R} \$$ & $\mathbf{1 6 6 . 6 8 9 , 6 3}$ \\
\hline
\end{tabular}

Fonte: Própria autoria.

Com base nesses dados foi possível verificar que a operação de ovos também era deficitária em $\mathrm{R} \$ 900.000,00$ por ano. A receita gerada em torno de $\mathrm{R} \$ 240.000,00$ por mês com venda de ovos e esterco não era suficiente para cobrir as despesas que totalizavam cerca de $R \$ 365.000,00$. A baixa produtividade das aves, entre $60 \%$ e $65 \%$, e o custo dos insumos para a ração eram os principais responsáveis por essa diferença negativa no resultado financeiro. O milho, principal insumo da ração, estava sendo adquirido ao preço de $R \$ 52,00 /$ saca, enquanto o preço médio do mercado estava em $\mathrm{R} \$ 45,00 /$ saca. Mas devido à restrição de crédito, o produtor se disponha a pagar $15,5 \%$ a mais para ter o produto. Isso ocorria também para os demais insumos.

Analisando as duas operações da empresa, ambas apresentavam resultados deficitários. Entretanto, as duas unidades de negócio demandariam investimentos em capital de giro e na reposição do plantel para continuar viáveis. Continuar com as duas operações ou focar apenas em uma eram as opções para a tomada de decisão que a empresa necessitaria naquele momento.

Para analisar as duas opções e definir uma delas foi utilizado o método da matriz de SWOT. Esse método permite analisar uma organização e seus ambientes com base nos pontos fortes (Strengths) e fracos (Weaknesses) como fatores 
internos da empresa, e as oportunidades (Opportunities) e ameaças (Threats) como fatores externos que podem influenciar as estratégias do negócio. A matriz estimula os gestores a analisarem a situação da empresa para desenvolver estratégias, táticas e ações que tornarão os objetivos organizacionais efetivos e eficientes (WEIHRICH, 1982).

Portanto, com a análise de SWOT foi possível entender as forças, as fraquezas, as oportunidades e as ameaças da empresa nas operações de ovos e suínos, conforme demonstrado nas Figuras 13 e 14.

Figura 13 - Análise de SWOT da operação de suínos

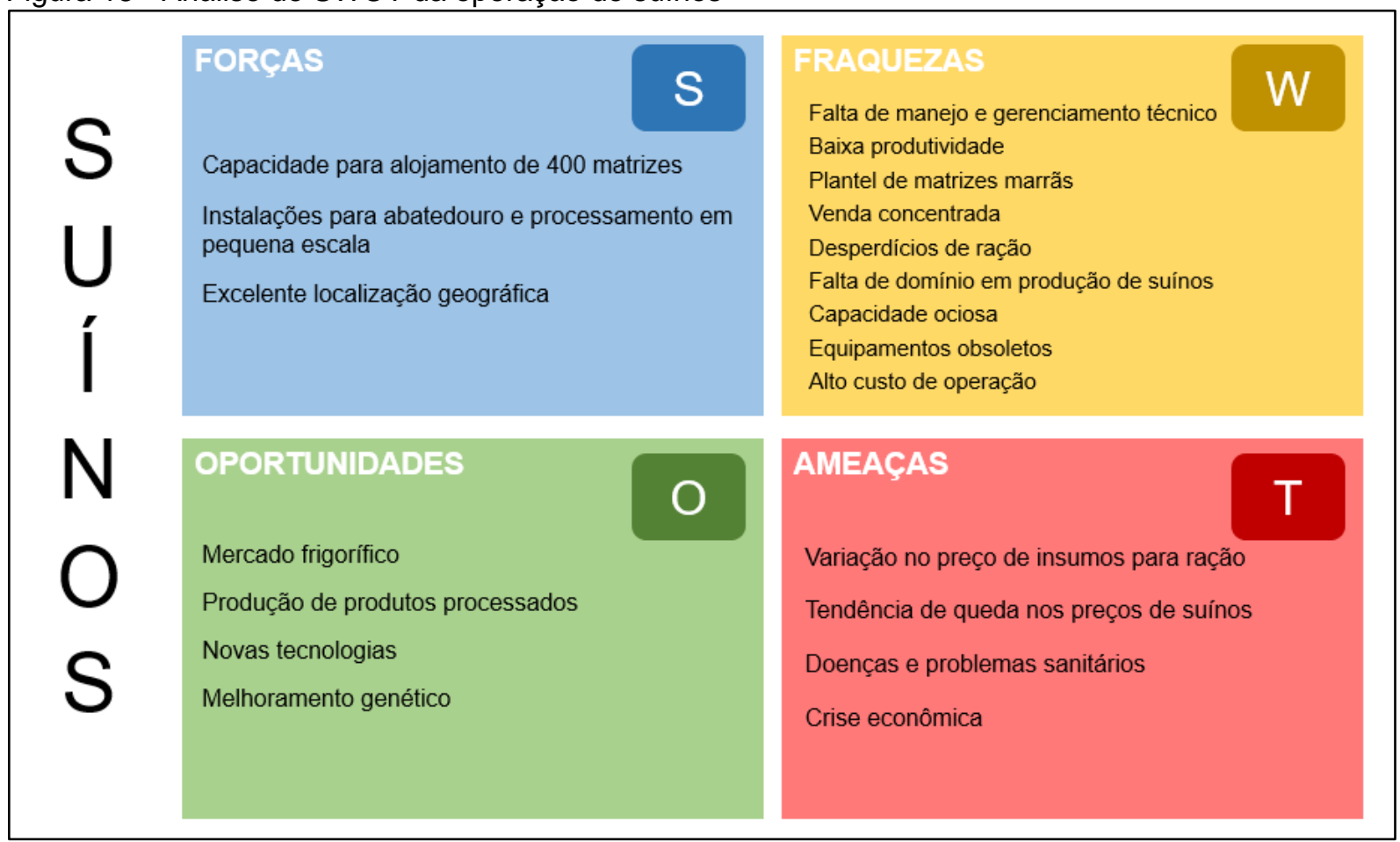

Fonte: Própria autoria. 
Figura 14 - Análise de SWOT da operação de ovos

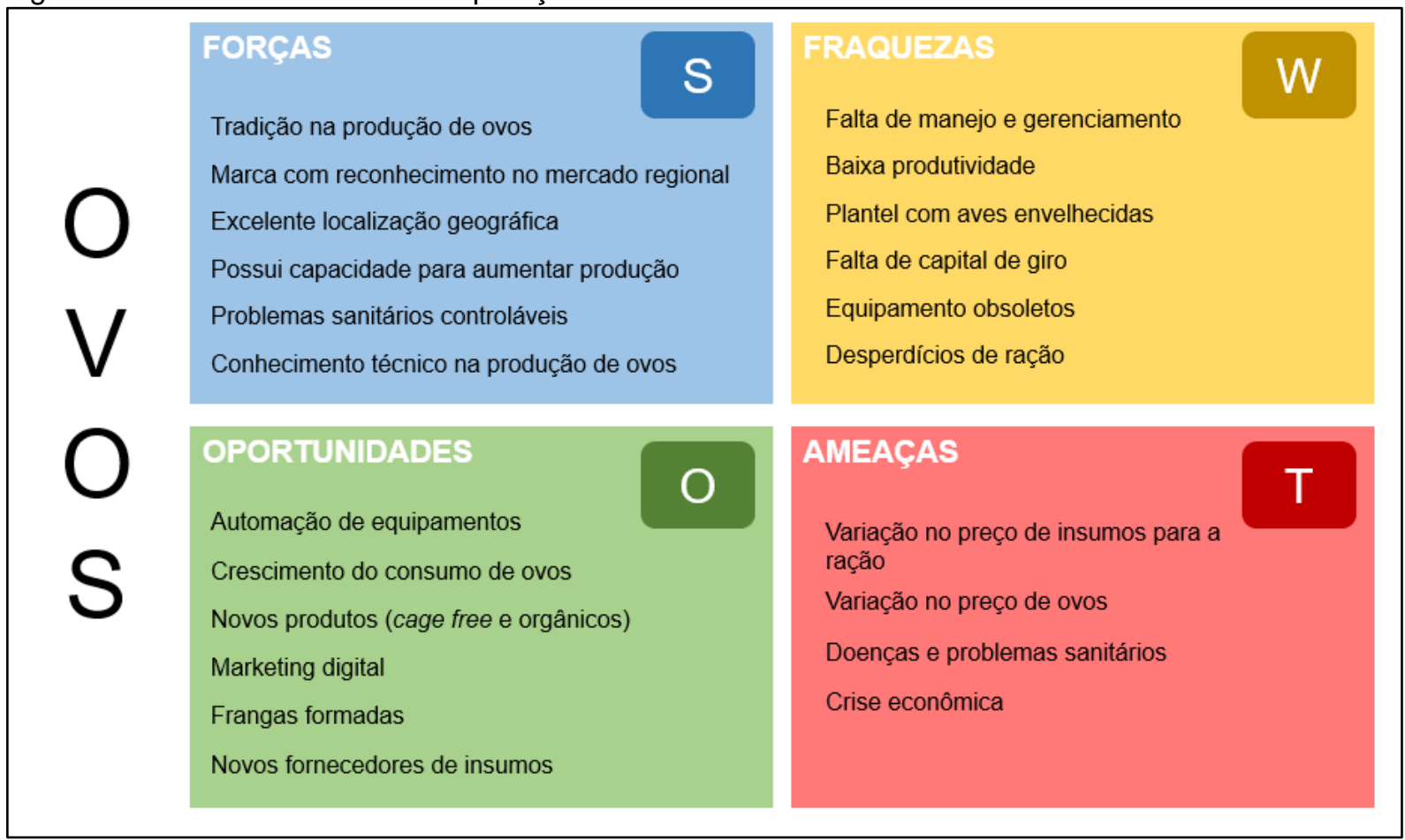

Fonte: Própria autoria.

Ao analisar criticamente os quadrantes das matrizes, a diretoria identificou que a operação de ovos continuava sendo a atividade que mais tinha se desenvolvido desde a fundação da empresa e que o foco nela reverteria os resultados financeiros em curto prazo, desde que fosse renovado o plantel e descartadas as matrizes de suínos. Já a operação de suínos efetivamente era uma operação que demandaria um investimento muito maior para torná-la eficiente e ainda assim teria um retorno incerto, pois dependeria do desempenho da capacitação técnica no manejo. A condição financeira da empresa não suportaria todo esse tempo.

Com os resultados contradizendo a visão dos diretores de que a unidade de suínos reverteria os resultados da empresa, a produção de ovos era a saída mais viável para a empresa do ponto de vista financeiro. Para o proprietário-gestor, tomar a decisão em encerrar a operação de suínos era muito difícil, pois havia um apego sentimental pelo negócio. Por essa razão, a decisão levou seis meses para ser colocada em prática. Durante todo esse tempo, a crise financeira se agravou ainda mais e as aves e os suínos passavam dias sem alimentação. 
À margem da falência, os diretores decidiram encerrar a atividade de produção de suínos e dedicar sua gestão à reestruturação da granja de ovos utilizando a ferramenta de fluxo de caixa recomendada pelo pesquisador.

Devido à ausência do controle de fluxo de caixa já mencionado, não foi possível calcular os indicadores financeiros a partir dessa ferramenta antes do modelo proposto nessa pesquisa. As informações financeiras relatadas nessa sessão foram coletadas de controles históricos da empresa e adequadas à operação daquele momento, bem como os valores atualizados com os preços de insumos, salários e outros custos e despesas vigentes no período.

\subsection{Os resultados com o uso da ferramenta de fluxo de caixa}

Em dezembro de 2016, a ferramenta de fluxo de caixa teve seus primeiros testes realizados e após sua validação e bom funcionamento, a ferramenta foi implementada na empresa em janeiro de 2017. Esse foi o primeiro mês que a empresa iniciou a venda das matrizes suínas como descarte para pequenos frigoríficos. Devido à dificuldade de obter dinheiro, neste período, o pesquisador controlava diariamente o fluxo de caixa com projeção de vendas e despesas para os próximos 90 dias.

Para aproveitar as vendas da quaresma, período sazonal em que o consumo e o preço dos ovos aumentam, foi planejado a compra de frangas que já estavam produzindo e que entrariam na produção com ovos de qualidade. A receita gerada pela venda de parte das matrizes descartadas em janeiro e fevereiro liquidou 0 pagamento das frangas e a alimentação das aves e dos suínos foi imediatamente estabilizada.

O controle do fluxo de caixa não estava mais sendo realizado por intuição, as receitas e despesas eram revisadas diariamente com o produtor e equilibradas de acordo com a movimentação diária do fluxo de caixa. Os pagamentos atrasados com fornecedores foram renegociados e, com isso, alguns deles passaram a acreditar nas mudanças e retomaram o crédito que até então estava suspenso. Os insumos de milho e soja eram negociados semanalmente com preços à vista e com novos fornecedores garantindo o preço médio dos insumos na região de Campinas/SP. 
Foi criado um comitê que se reunia de três a quatro vezes por semana para revisar o fluxo de caixa da próxima semana. Participavam desse comitê o pesquisador, os diretores e a assistente financeira. Uma nova estrutura organizacional foi proposta e com isso a diretora, esposa do produtor, passou a ser a gestora da área comercial. Toda semana ela recebia do pesquisador uma previsão de necessidade de dinheiro para a próxima semana. Como a maior parte das vendas de ovos era à vista, a dinâmica dessa previsão funcionava muito bem.

Os salários dos funcionários, assim como o décimo terceiro e outros benefícios que estavam atrasados passaram a ser priorizados e ao final do primeiro trimestre já estavam liquidados. Os diretores passaram a ter salários fixos por mês, sendo que estes foram calculados de acordo com o orçamento doméstico do casal acrescidos de um rendimento variável conforme o resultado apurado. As finanças pessoais do casal que até antes do uso do fluxo de caixa eram incorporadas nas finanças da empresa, passaram a ser independentes.

Ao final do primeiro semestre, a idade média do plantel de aves havia reduzido de 120 semanas para 50 semanas e os indicadores financeiros apontavam para uma melhora no desempenho financeiro, conforme demonstrado a seguir no Quadro 18.

Quadro 18 - Indicadores financeiros - 10 Semestre de 2017

\begin{tabular}{|c|c|c|c|c|c|c|c|}
\hline & JAN & FEV & MAR & ABR & MAI & JUN & ACUM. 15 \\
\hline Estamos rentáveis? & $4,1 \%$ & $2,8 \%$ & $9,4 \%$ & $26,1 \%$ & $20,3 \%$ & $24,3 \%$ & $15,9 \%$ \\
\hline Quanto utilizamos para reinvestir? & $21,5 \%$ & $0,0 \%$ & $194,2 \%$ & $0,0 \%$ & $39,2 \%$ & $6,8 \%$ & $33,0 \%$ \\
\hline Quanto utilizamos para pagamento de dívidas? & $35,4 \%$ & $74,6 \%$ & $-42,6 \%$ & $3,1 \%$ & $46,9 \%$ & $61,1 \%$ & $31,8 \%$ \\
\hline Qual a nossa geração de caixa (aumento de saldo)? & $43,1 \%$ & $25,4 \%$ & $-51,6 \%$ & $96,9 \%$ & $13,9 \%$ & $32,1 \%$ & $35,2 \%$ \\
\hline Saldo mínimo de caixa necessário & $-9,4 \%$ & $-9,2 \%$ & $-21,3 \%$ & $64,2 \%$ & $52,7 \%$ & $82,4 \%$ & $95,4 \%$ \\
\hline
\end{tabular}

Fonte: Própria autoria.

A rentabilidade no período foi de $15,9 \%$, isto é, para cada $R \$ 1,00$ de receita gerada, a operação convertia $R \$ 0,16$ como resultado líquido das atividades operacionais, $33,0 \%$ desse resultado foi utilizado para as melhorias nas instalações e equipamentos da fábrica de rações, do entreposto e dos galpões de recria e 31,8\% foi utilizado para o pagamento das dívidas diante das renegociações que ocorreram nesse período para que a empresa conseguisse retomar o fornecimento de parte dos principais insumos para a ração e embalagens.

A geração de caixa foi de $35,2 \%$ com relação ao resultado operacional e o saldo mínimo necessário para a operação evoluiu de números negativos no início do período para $95,4 \%$ do montante que era necessário. Como o foco da empresa no 
primeiro semestre era tornar a operação de postura viável, as receitas obtidas durante o período estavam distribuídas em $83 \%$ com vendas de ovos, $14 \%$ com vendas de descarte de suínos e $3 \%$ com vendas de resíduos (esterco, descarte de aves, embalagens e outros).

Gráfico 16 - Distribuição das receitas - 1ํ Semestre de 2017

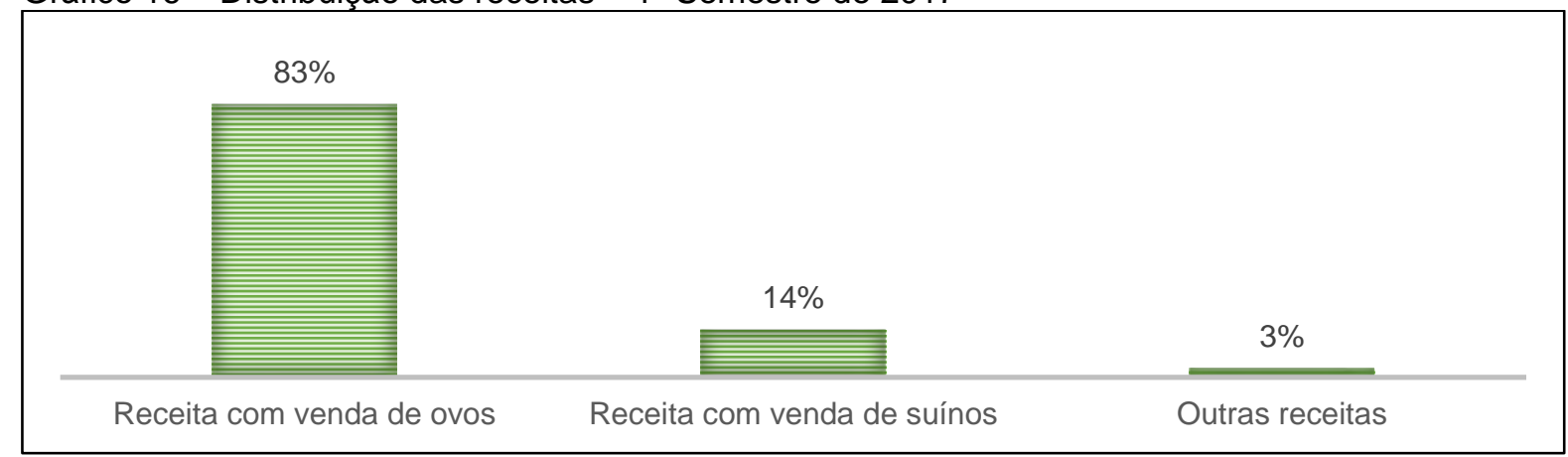

Fonte: Própria autoria.

O desempenho do período teve contribuição de vários fatores, dentre eles a redução dos preços dos insumos para ração, como milho e farelo de soja, que correspondem de $60 \%$ a $70 \%$ do total do custo da operação. O valor da saca de milho ao final do primeiro semestre de 2017 era de $R \$ 25,49$ por saca, ante $R \$ 41,28$ no mesmo período do ano anterior, ou seja, uma variação de $61,9 \%$ a menos (CEPEA, 2019a).

O farelo de soja apresentou uma redução de $49,6 \%$ no preço da tonelada no mesmo período comparado com o ano de 2016 e o preço da caixa de ovo com 30 dúzias aumentou $8,1 \%$ nessa mesma relação de períodos (CEPEA, 2019b; CEPEA, 2019c). Durante o mês de abril, o consumo de milho foi garantido pela produção de uma parte da área de plantio da propriedade, contribuindo grandemente para a geração de caixa.

A empresa conseguiu honrar os pagamentos de passivos fiscais e empréstimos de curtos prazo. As compras de materiais e insumos, em sua grande maioria, eram adquiridas com pagamento à vista e muito bem negociadas a fim de reduzir os custos. Assim, o caixa gerado acumulado no primeiro semestre agregou $\mathrm{R} \$ 158.083,00$ ao saldo das disponibilidades da empresa. Este valor resulta da soma dos fluxos de caixa das atividades operacionais, investimentos e financiamentos.

Com os resultados financeiros positivos e a operação retomando suas forças com a organização das finanças, a partir do segundo semestre, a empresa passou a 
investir na gestão, contratando funcionários mais qualificados para 0 setor administrativo, produção e comercial; retomou as operações do setor de recria das aves, que até então estava desativada, aumentando o plantel de 60.000 aves para 90.000 aves; realizou melhorias nos galpões de produção e de classificação dos ovos; investiu em marketing, criando novos rótulos para embalagens, site e divulgação da marca em mídias sociais; adquiriu um novo sistema ERP especializado em avicultura de postura para a gestão de produção e financeira; reduziu a rotatividade de funcionários com a implementação de um processo de recrutamento e reorganizou a estrutura organizacional com a criação de um conselho administrativo responsável pelo planejamento estratégico.

Figura 15 - Organograma após o uso do fluxo de caixa

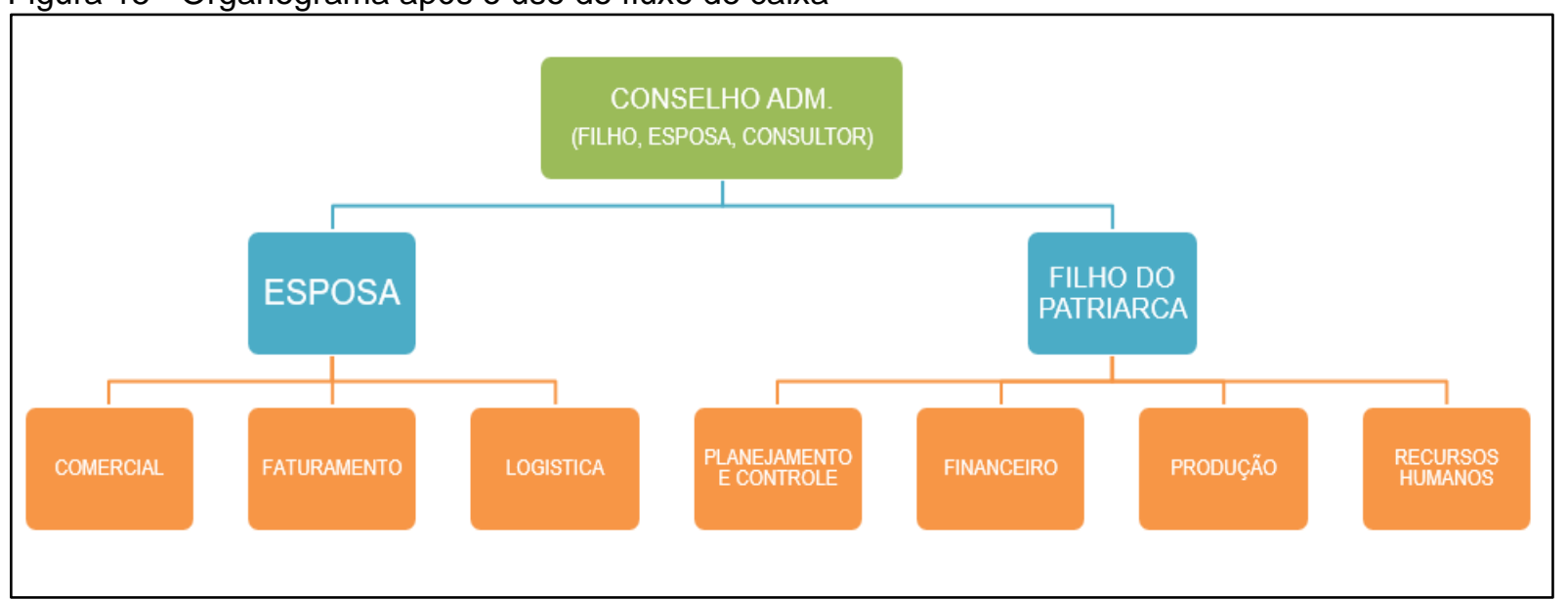

Fonte: Própria autoria.

Assim, com a gestão rigorosa de fluxo de caixa, o reposicionamento estratégico do negócio com foco na produção de ovos e a reestruturação de toda a empresa, os diretores conseguiram conquistar as primeiras redes de supermercados da região. O resultado acumulado da atividade operacional da empresa, que estava à margem da falência, foi de $\mathrm{R} \$ 929.605,65$ ao final de dezembro de 2017.

Quadro 19 - Indicadores financeiros - 20 Semestre de 2017

\begin{tabular}{|l|c|c|c|c|c|c|c|c|}
\hline & JUL & AGO & SET & OUT & NOV & DEZ & ACUM. 2S & ACUM. ANO \\
\hline Estamos rentáveis? & $46,1 \%$ & $25,8 \%$ & $13,7 \%$ & $4,5 \%$ & $-4,6 \%$ & $-14,5 \%$ & $15,3 \%$ & $\mathbf{1 5 , 6 \%}$ \\
Quanto utilizamos para reinvestir? & $4,0 \%$ & $17,9 \%$ & $40,1 \%$ & $150,2 \%$ & $-150,1 \%$ & $-46,5 \%$ & $33,1 \%$ & $\mathbf{3 3 , 1} \%$ \\
Quanto utilizamos para pagamento de dívidas? & $46,8 \%$ & $23,0 \%$ & $68,6 \%$ & $94,6 \%$ & $-63,6 \%$ & $-16,0 \%$ & $56,1 \%$ & $\mathbf{4 4 , 4 \%}$ \\
Qual a nossa geração de caixa (aumento de saldo)? & $49,3 \%$ & $59,1 \%$ & $-8,8 \%$ & $-144,8 \%$ & $313,7 \%$ & $162,5 \%$ & $10,7 \%$ & $\mathbf{2 2 , 5 \%}$ \\
Saldo mínimo de caixa necessário & $221,5 \%$ & $219,3 \%$ & $241,2 \%$ & $208,7 \%$ & $172,7 \%$ & $108,8 \%$ & $117,0 \%$ & $\mathbf{1 2 3 , 6 \%}$ \\
\hline
\end{tabular}

Fonte: Própria autoria. 
De acordo com o Quadro 19, os valores empenhados nas atividades de investimentos com reformas na estrutura de produção e na reposição do plantel resultaram em $33,1 \%$ das atividades operacionais. As atividades de financiamento com os pagamentos de juros e de dívidas renegociadas com fornecedores, bancos e terceiros totalizou o montante de $56,1 \%$. A dedicação maior no pagamento dos passivos diminuiu a geração de caixa ao final do segundo semestre em 24,5 pontos percentuais com relação ao primeiro semestre. Entretanto, mesmo com a redução da geração de caixa, a empresa conseguiu superar a necessidade do saldo mínimo de caixa, mantendo-se 17,0\% acima do limite necessário.

A rentabilidade do segundo semestre se manteve no patamar de $15,0 \%$ com relação ao primeiro semestre. Segundo Kakimoto (2011) e a demonstração do Gráfico 7, os preços de venda de ovos no segundo semestre diminuírem devido a sazonalidade e, a partir do mês de setembro as receitas diminuíram em $27 \%$. O preço de venda da caixa de ovos ao final do mês de junho de 2017 era de $R \$ 92,17$ contra $R \$ 72,75$ ao final do mês de dezembro do mesmo ano (CEPEA, 2019b). Não apenas os preços de venda reduziram como também os preços de milho e o farelo de soja aumentaram de um semestre para outro. O milho sofreu aumento de $32,4 \%$ e o farelo de soja de 8,5\% (CEPEA, 2019a; CEPEA, 2019c).

Nota-se no Quadro 19 que a rentabilidade nos meses de novembro e dezembro ficaram negativas com o impacto da redução das receitas e aumentos dos custos dos principais insumos da ração. Saindo de um cenário crítico financeiramente, a empresa demonstrou pelos indicadores a capacidade de manter a operação em continuidade. As receitas obtidas com as vendas de leitões e descarte das matrizes suínas finalizaram no mês de setembro e corresponderam em $10,2 \%$ nas receitas totais geradas nos dois semestres de 2017 .

Gráfico 17 - Distribuição das receitas - Acumulado de 2017

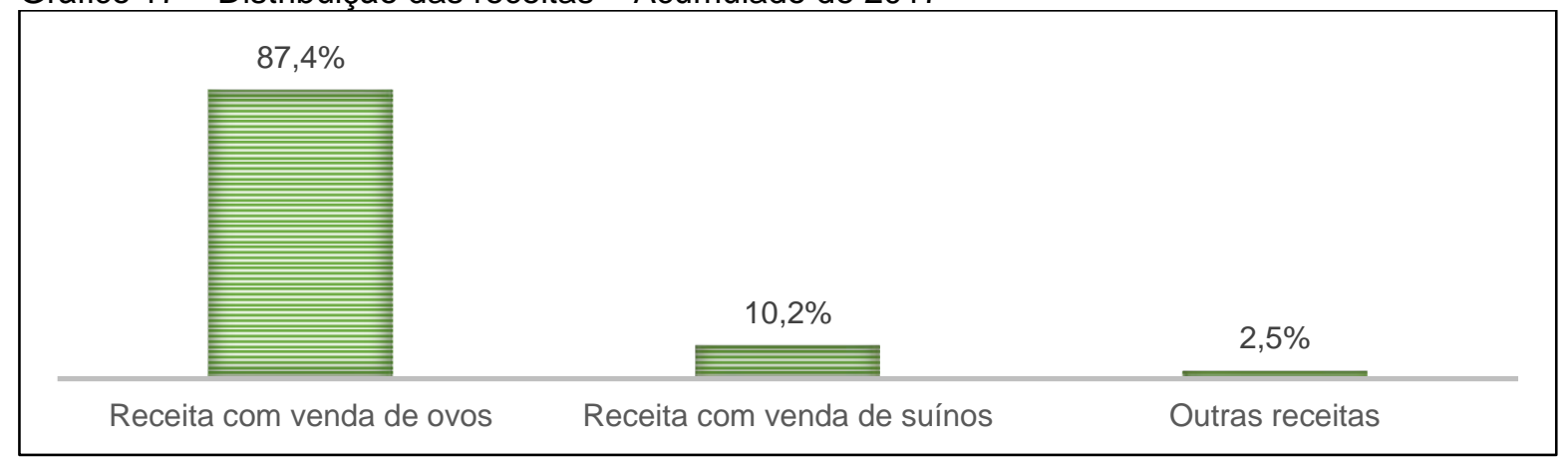

Fonte: Própria autoria. 
A dedicação do pesquisador juntamente com os dirigentes no controle do fluxo de caixa garantiu à empresa uma geração de caixa acumulada ao final do ano de $R \$ 209.591,51$ agregando esse montante ao saldo final das disponibilidades. A variação do saldo final das disponibilidades com relação ao início do período foi de $951,5 \%$, contribuindo para a composição do saldo mínimo de caixa, que resultou 23,6\% acima do limite do saldo mínimo de caixa. A geração de caixa da empresa poderia ter atingido $66,9 \%$ se não houvesse desembolsos para pagamento de dívidas e financiamentos, porém os pagamentos das dívidas diminuíram em 19,6\% o saldo do endividamento.

Os prazos médios calculados com base nas movimentações do período tiveram os seguintes resultados:

Quadro 20 - Cálculo dos prazos médios da operação

\begin{tabular}{|l|c|}
\hline \multicolumn{2}{|c|}{ PRAZOS MÉDIOS DA OPERAÇÃO } \\
\hline Estoque de insumos e embalagens (em dias) & 10 \\
\hline Estoque de produto acabado (em dias) & 5 \\
\hline Recebimento de clientes (em dias) & 217 \\
\hline Pagamento de fornecedores (em dias) & 11 \\
\hline Ciclo de caixa (em dias) & \\
\hline
\end{tabular}

Fonte: Própria autoria.

Os prazos médios de estocagem, recebimento de clientes e pagamento de fornecedores ajudaram a empresa a formar o capital de giro que até então estava zerado. Além dos ajustes nos prazos de recebimento de vendas e de pagamentos dos insumos, a receita gerada com a extinção da granja de suínos teve relevante participação na formação do capital de giro.

\subsection{Implicações gerenciais}

Em primeiro lugar, buscou-se diagnosticar os principais problemas que levaram ao cenário crítico que a empresa estava vivenciando. Aplicando a metodologia da pesquisa ação proposta por Coughlan e Coghlan (2002) foi possível não apenas identificar as causas como também avaliar os dados na matriz de SWOT. 
Além do acesso às informações relevantes durante a coleta de dados, esse trabalho possibilitou ao pesquisador participar ativamente nas tomadas de decisões juntamente com a diretoria de forma imparcial e sem conflito de interesses.

A escolha pelo modelo de fluxo caixa proposto pelo FASB (1987) e adaptado pelo pesquisador para a utilização nesse projeto permitiu ao produtor a organização, o planejamento financeiro e o aumento da eficiência do negócio. A partir do uso da ferramenta, as decisões e os controles financeiros tornaram mais organizados e planejados evitando a falência do negócio.

Esse apontamento do autor vai ao encontro do que é apresentado por Afrifa (2016), Ross, Westerfield, Jaffe (2002) e Yahya, Ali, Ghazali (2016) afirmando que o monitoramento do fluxo de caixa como ferramenta de gestão ajuda a reorganizar financeiramente, sobreviver, evitar dificuldades financeiras, perder eficiência operacional e sofrer uma possível falência.

Também é importante afirmar que o sucesso e o fracasso das PMEs, segundo Escrivão Filho et al. (2017), estão fortemente ligados às características individuais do proprietário-gestor em influenciar o desempenho do negócio. Portanto, o fluxo de caixa é apenas uma ferramenta que orientará o gestor e, por isso, seu monitoramento precisa ser tratado com diligência pelos dirigentes, a fim de garantir os melhores resultados. Caso contrário, a empresa estará sujeita à falência. 


\section{CONCLUSÃO}

Diante do exposto nesse trabalho fica evidente que pequenos e médios produtores rurais devem dar a atenção primordial ao fluxo de caixa. Este trabalho demonstrou que a reestruturação da empresa realizada a partir da ferramenta de fluxo de caixa asseguraram a sua continuidade, que até então se encontrava à margem da falência.

O controle rigoroso de fluxo de caixa é considerado uma atividade essencial para evitar o caos em uma pequena e média empresa. A ausência de um fluxo de caixa possibilita a falência da empresa, mesmo que ela apresente lucro. Para Welsh e White (1981), a ferramenta é mais importante do que o valor do lucro ou do retorno do investimento, e conseguir honrar os pagamentos é uma questão de vida ou morte para as pequenas empresas.

Os três objetivos propostos nesse trabalho foram alcançados com resultados bastante satisfatórios e com embasamento teórico que amparou a análise e as conclusões.

Os resultados financeiros obtidos proporcionaram ao negócio não apenas melhorias financeiras, mas de gestão organizacional mediante processos, mudança de comportamento e visão dos dirigentes.

A decisão de focar apenas na atividade de produção de ovos retomou a expertise da empresa que havia sido construída desde a fundação do negócio. Os resultados positivos com a operação de ovos demonstraram que as debilidades apontadas na análise de SWOT foram assertivas para a tomada de decisão.

Entretanto, deve-se considerar que a intensidade, a persistência, o cuidado e a prudência na gestão financeira por parte dos diretores podem prevenir sucessivas crises financeiras sem perspectivas de recuperação. Embora os resíduos dos períodos de crises não tenham sido eliminados de imediato, a reestruturação financeira a partir do fluxo de caixa buscou manter a empresa financeiramente viável com capacidade de continuar suas operações a fim de honrar, nos próximos cinco anos, as obrigações renegociadas.

Mesmo com a reeducação financeira e a aprendizagem de negociação durante a gestão do fluxo de caixa, o proprietário-gestor, por apresentar um olhar cômodo e sentir-se aparentemente confortável com o novo cenário, tomava decisões que impactavam o negócio negativamente. Ele tomava tais decisões sem 
compartilhá-las nas reuniões do conselho ou analisar detalhadamente se estas trariam rentabilidade imediata ao negócio. Por receio de ver contrariados seus pensamentos sobre o que o levaria a um novo patamar de sucesso, mas seguro com a disponibilidade de dinheiro em caixa naquele momento, preferia arriscar-se sem planejamento, apenas para mostrar o reconhecimento do seu status de proprietário.

É importante enfatizar, que os pequenos e médios produtores rurais - assim como todos os demais empresários -, precisam saber como administrar o dinheiro gerado em caixa, a fim de beneficiar a empresa, ao invés de apenas utilizá-lo para aumentar seu padrão de vida pessoal ou aplicar seu uso incorretamente na gestão do negócio.

Portanto, o sucesso de uma pequena ou média empresa está associado à gestão de fluxo de caixa e às competências e comportamento do proprietário-gestor. O fluxo de caixa não é apenas uma ferramenta com um demonstrativo financeiro que pode garantir a recuperação de uma empresa, mas também é uma ferramenta que pode aumentar a eficiência do negócio.

\subsection{Limitações da pesquisa}

A pesquisa demonstrou, de forma prática e empírica, os principais aspectos do impacto do fluxo de caixa em um processo de reestruturação em uma média empresa avícola de postura comercial. O pesquisador buscou explorar sua experiência profissional em gestão de empresas com o objetivo de promover as melhores práticas durante o projeto.

Entretanto, não foi explorado nesse trabalho a aplicação do Balanço Patrimonial e da Demonstração de Resultados como instrumentos para a tomada de decisões financeiras, bem como seu tratamento com ativos biológicos. Devido à complexidade de entendimento contábil por parte dos pequenos e médios produtores rurais, essas peças contábeis foram mencionadas na revisão teórica apenas à título de conhecimento.

Outra limitação é referente aos resultados obtidos e conclusões da pesquisa. O cenário vivenciado nesse trabalho é bastante específico e único. Portanto a extrapolação para outros cenários pode não garantir os mesmos resultados. 


\subsection{Futuras pesquisas}

O Brasil é um país em desenvolvimento e em constante mudanças nas políticas econômicas e sociais e, o agronegócio possui grande relevância para a economia.

Para pesquisas futuras, o pesquisador sugere que outros pesquisadores busquem abordar o aprimoramento da ferramenta com a integração dos demonstrativos contábeis - Balanço Patrimonial e DRE - para pequenos e médios produtores rurais, independentemente do tipo de produção, de forma simples e prática para a gestão do negócio, levando em consideração o impacto dos ativos biológicos e seus ciclos nos resultados.

Sugere-se, ainda, o aprimoramento de pesquisas ligadas à gestão de resultados por indicadores de desempenho para produtores rurais. 


\section{REFERÊNCIAS}

AFRIFA, G. A. Net working capital, cash flow and performance of UK SMEs. Review of Accounting and Finance, Bingley, v. 15, n. 1, p. 21-44, 2016.

AKTAS, N.; CROCI, E.; PETMEZAS, D. Is working capital management valueenhancing? Evidence from firm performance and investments. Journal of Corporate Finance, Amsterdam, v. 30, p. 98-113, 2015.

ALBUQUERQUE, A. F.; ESCRIVÃO FILHO, E. Gestão estratégica das informações na pequena empresa hoteleira: apresentação de propostas de melhorias no gerenciamento das informações internas. Revista de Gestão USP, São Paulo, v.14, n. 4, p. 47-62, out./dez. 2007.

ALMEIDA, H.; CAMPELLO, M.; WEISBACH, M. S. The cash flow sensitivity of cash. The Journal of Finance, New York, v. 59, n. 4, p. 1777-1804, 2004.

AMARAL, G. et al. Avicultura de postura: estrutura da cadeia produtiva, panorama do setor no Brasil e no mundo e o apoio do BNDES. BNDES Setorial, Rio de Janeiro, n. 43, p. 167-207, 2016.

ASSAF NETO, A.; SILVA, C. A. T. Administração do capital de giro. 4. ed. São Paulo: Atlas, 2012

ASSOCIAÇÃO BRASILEIRA DE PROTEÍNA ANIMAL - ABPA. Relatório anual 2018. São Paulo, SP, 2018. Disponível em:

$<$ http://abpabr.com.br/setores/avicultura/publicacoes /relatorios-anuais >. Acesso em: 10 dez. 2018.

AUSTRALIA. Small Business Development Corporation. Profit \& loss and balance sheets. Government of Western Australia, 2018. Disponível em $<$ https://www.smallbusiness.wa.gov.au/business-advice/financial-management/ reviewing-your-finances\#pl>. Acesso em: 08 out. 2018.

BANCO CENTRAL DO BRASIL - BCB. Sistema de informação de crédito:

documento 3040 - Dados de Risco de Crédito (instruções de preenchimento). 2018. Disponível em:

$<$ https://www.bcb.gov.br/fis/crc/ftp/scr_instrucoesdepreenchimento_doc3040.pdf>. Acesso em: 20 out. 2018.

BANCO NACIONAL DO DESENVOLVIMENTO ECONÔMICO E SOCIAL - BNDES. Quem pode ser cliente. 2018. Disponível em:

$<$ https://www.bndes.gov.br/wps/portal/site/home/ financia mento/guia/quem-podeser-cliente/>. Acesso em: 20 out. 2018.

BARDIN, L. Análise de conteúdo. Lisboa: Edições 70, 2006.

BIELIKOVA, A.; MAZANEC, J. Small and medium-sized enterprises in the global economy. International Journal of Scientific \& Engineering Research, Raipur, v. 7, n.10, out. 2016. 
BIRLEY, S.; NIKTARI, N. Reasons for business failure. Leadership \& Organization Development Journal, Bingley, v. 17, n. 2, p. 52, 1996

BOER, F. P. The valuation of technology: business and financial issues in R\&D. New York: John Wiley \& Sons, 1999.

BORTOLI NETO, A. Tipologia de problemas das pequenas e médias empresas. 1980. 201 p. Dissertação (Mestrado em Administração) - Faculdade de Economia, Administração e Contabilidade, Universidade de São Paulo, São Paulo, 1980.

BRASIL. Lei 11.638 de 28 de dezembro de 2007. Altera e revoga dispositivos da Lei no 6.404, de 15 de dezembro de 1976, e da Lei no 6.385, de 7 de dezembro de 1976, e estende às sociedades de grande porte disposições relativas à elaboração e divulgação de demonstrações financeiras. Diário Oficial da União, Poder Legislativo, Brasília, DF, 28 dez. 2007. Edição extra, p.2.

. Lei Complementar 123 de 14 de dezembro de 2006. Institui o Estatuto Nacional da Microempresa e Empresa de Pequeno Porte. Diário Oficial da União, Poder Legislativo, Brasília, DF, 15 dez. 2006a. Disponível em:

<http://www.planalto.gov.br/ccivil_03/LEIS/LCP/Lcp123.htm>. Acesso em: 10 out. 2018.

. Projeto de Lei do Senado n. 325. Brasília, DF: Senado, 2006b. Disponível em: <https://www25.senado.leg.br/web/atividade/materias/-/materia/79603>. Acesso em: 10 out. 2018.

. Ministério da Agricultura, Pecuária e Abastecimento. Valor da produção fecha 2018 em R\$569,8 bilhões. Notícias, 15 jan. 2019. Disponível em: $<$ http://www.agricultura.gov.br/noticias/valor-da-producao-fecha-2018-em-r-569-8bilhoes>. Acesso em: 20 jan. 2019.

CENTRO DE ESTUDOS AVANÇADOS EM ECONOMIA APLICADA - CEPEA. PIB do agronegócio brasileiro. 2018. Disponível em:

<https://www.cepea.esalq.usp.br/br/pib-do-agronegocio-brasileiro.aspx>. Acesso em: 02 dez. 2018.

Indicador do milho ESALQ/BM\&FBOVESPA. Disponível em <https://www.cepea.esalq.usp.br/br/indicador/milho.aspx>. Acesso em: 02 jan. 2019a.

. Consulta - Série histórica [mensagem pessoal]. Mensagem recebida por <ovocepea@usp.br> em 11 fev. 2019b.

Série histórica farelo de soja [mensagem pessoal]. Mensagem recebida por <gracepea@usp.br> em 11 fev. 2019c.

CHEATHAM, L.; CHEATHAM, C. Utilizing financial statements as cash flow planning and control tools. Managerial Finance, Bradford, v. 19, n. 8, p. 35-49, 1993. 
COGHLAN, D.; BRANNICK, T. Doing action research in your own organization. London: Sage, 2001.

COUGHLAN, P.; COGHLAN, D. Action research for operations management. International Journal of Operations \& Production Management, v. 22, n. 2, p.220-240, 2002.

COMISSÃO DE VALORES MOBILIÁRIOS - CVM. Deliberação n. 29: Estrutura Conceitual Básica da Comissão da Contabilidade. Brasília, DF: CVM, 1986.

COMITÉ DE PRONUNCIAMENTOS CONTÁBEIS - CPC. Pronunciamento Técnico CPC 03: demonstração dos fluxos de caixa. Brasília, DF: CPC, 2008.

. Pronunciamento Técnico CPC PME (R1): contabilidade para pequenas e médias empresas. Brasília, DF: CPC, 2009.

. Pronunciamento Técnico CPC 03 (R2): demonstração dos fluxos de caixa. Brasília, DF: CPC, 2010.

Pronunciamento Técnico CPC 26 (R1): apresentação das demonstrações contábeis. Brasília, DF: CPC, 2011.

CONSELHO FEDERAL DE CONTABILIDADE - CFC. Princípios fundamentais e normas brasileiras de contabilidade. 3. ed. Brasília, DF: CFC, 2008. Disponível em:

$<$ https://s3.amazonaws.com/academia.edu.documents/35181711/Livro_Principios-eNBCs.pdf?AWSAccessKeyld=AKIAIWOWYYGZ2Y53UL3A\&Expires $=1539647646 \& S$ ignature $=\% 2 B j o O v f J P W t e T f n V e R w R j R Z e 7 r y M \% 3 D \&$ response-content-

disposition=inline\%3B\%20filename\%3DLivro_Principios-e-NBCs.pdf>. Acesso em: 15 out. 2018.

DAS, S. Analysis of cash flow ratios: a study on CMC. Accounting, North Vancouver, v. 4, n. 1, p. 41-52, 2017.

DELOOF, M. Does working capital management affect profitability of belgian firms? Journal of Business Finance \& Accounting, Oxford, v. 30, n. 4, p. 573-588, 2003.

ESCRIVÃO FILHO, E. et al. Identifying SME mortality factors in the life cycle stages: an empirical approach of relevant factors for small business owner-managers in Brazil. Journal of Global Entrepreneurship Research, Tehran, v. 7, n. 5, p. 1-15, 2017.

FASSARELA, R. A.; COVRE, J. Cadeia produtiva da avicultura de postura: um estudo no munícipio de Santa Maria de Jequitibá no Estado do Espirito Santo. In: CONGRESSO DA SOCIEDADE BRASILEIRA DE ECONOMIA, ADMINISTRAÇÃO E SOCIOLOGIA RURAL, 48., 2010, Campo Grande. Anais... Campo Grande: SOBER, 2010. p. 1-19. 
FEDERAÇÃO DAS INDÚSTRIAS DO ESTADO DE SÃO PAULO - FIESP. Índice de Confiança do Agronegócio (ICAGRO): perfil do produtor. Disponível em: <http://icagro.fiesp.com .br/perfilprodutor.asp>. Acesso em: 10 out. 2018.

FERREIRA, L. F. F. et al. Análise quantitativa sobre a mortalidade precoce de micro e pequenas empresas da cidade de São Paulo. Gestão e Produção, São Carlos, v. 19, n. 4, p. 811-823, 2012.

FERREIRA, M. A.; VILELA, A. S. Why do firms hold cash? Evidence from EMU countries. European Financial Management, Oxford, v. 10, n. 2, p. 295-319, 2004.

FINANCIAL ACCOUNTING STANDARDS BOARD - FASB. FAS95: Statement of Financial Accounting Standards n.95, Statement of cash flows. Stamford, 1987.

FOOD AND AGRICULTURE ORGANIZATION OF THE UNITED NATIONS - FAO. Food balance sheets (production poultry meat). FAOSTAT, 2013a. Disponível em <http://www.fao.org/faostat/en/\#data>. Acesso em: 02 dez. 2018.

. Food balance sheets (production eggs). FAOSTAT, 2013b. Disponível em <http://www.fao.org/faostat/en/\#data>. Acesso em: 02 dez. 2018.

Value of agricultural production. FAOSTAT, 2016. Disponível em <http://www.fao.org/faostat/en/\#data>. Acesso em: 02 dez. 2018.

FRANCISCO, J. R. S. et al. Demonstração de fluxo de caixa - atividade operacional versus indicadores financeiros de liquidez na análise da gestão financeira. Revista de Contabilidade e Controladoria, Curitiba, v. 3, n. 2, p. 94-111, mai./ago. 2001.

FRENCH, S. Action research for practising managers. Journal of Management Development, Bingley, v. 28, n. 3, p.187-204, 2009.

GIACOMINO, D. E.; MIELKE, D. E. Cash flows: another approach to ratio analysis. Journal of Accountancy, New York, p. 55-58, 1993. Disponível em:

<http://link.galegroup.com/apps/doc/A13663207/GPS?u=usp_br\&sid=GPS\&xid=1e01 e5a6>. Acesso em: 8 nov. 2018.

GIL, A. C. Como elaborar projetos de pesquisa. 4. ed. São Paulo: Atlas, 2002

GITMAN, L. J. Princípios de administração financeira. 7. ed. São Paulo: Harbra, 1997.

GODOY, A.S. Pesquisa qualitativa: tipos fundamentais. Revista de Administração de Empresas (RAE), São Paulo, v. 35, n. 3, p. 20-29, 1995.

GUILDING, C.; PIZAM, A. International encyclopedia of hospitality management. In: GUILDING, C. Profit and loss statement. 2nd ed. Oxford: Elsevier, 2010.

Disponível em: <http://citeseerx.ist.psu.edu/viewdoc/download?

doi=10.1.1.465.1606\& rep=rep1\&type=pdf\#page=556>. Acesso em: 27 set. 2018. 
HASKINS, M. E.; HIGGS, R. D.; KETZ, J. E. Cash flow planning. Planning Review, Dayton, v. 15, n. 6, p. 38-44, 1987.

HAYES, S.; SILVA, P. The chart of accounts: opportunities and pitfalls. The Bottom Line, New York, v. 5, n. 4, p.37-39, 1992.

HILL, M. D.; KELLY, G. W.; HIGHFIELD, M. J. Net operating working capital behavior: a first look. Financial Management, Tampa, v. 39, p. 783-805, 2010.

INSTITUTO BRASILEIRO DE GEOGRAFIA E ESTATÍSTICA - IBGE. As micro e pequenas empresas comerciais e de serviços no Brasil 2001. Rio de Janeiro: IBGE, 2003. (Estudos e Pesquisas Informações Econômica, 1). Disponível em: $<$ https://biblioteca.ibge.gov.br/visualizacao/livros/liv1898.pdf>. Acesso em: 20 dez. 2018.

Demografia das empresas 2015. Rio de Janeiro: IBGE, 2017a. (Estudos e Pesquisas Informação Econômica, 29). Disponível em:

$<$ https://biblioteca.ibge.gov.br/visualizacao/livros/liv101151.pdf>. Acesso em: 20 dez. 2018.

Censo Agropecuário 2017 (Resultados Preliminares). Rio de Janeiro: IBGE, 2017b. (Censo agropecuário, v. 7). Disponível em: <https://biblioteca.ibge.gov.br/visualizacao/periodicos/3093/agro_2017_resultados_ preliminares.pdf>. Acesso em: 20 dez. 2018.

. Puxado pela agricultura, PIB cresce 1,0\% em 2017 e chega a $\mathbf{R} \$ 6,6$ trilhões. Brasília> Agência IBGE (Estatísticas Econômicas), 10 abr. 2018a. Disponível em: <https://agenciadenoticias.ibge.gov.br/agencia-noticias/2012agencia-de-noticias/noticias/20168-puxado-pela-agricultura-pib-cresce-1-0-em-2017e-chega-a-r-6-6-trilhoes>. Acesso em: 02 dez. 2018.

Produção de ovos de galinha. Sistema IBGE de Recuperação Automática (SIDRA), 2018b. Disponível em <https://sidra.ibge.gov.br/pesquisa/pog/Quadros>. Acesso em: 02 dez. 2018.

INSTITUTO NACIONAL DE COLONIZAÇÃO E REFORMA AGRÁRIA - INCRA. Classificação dos imóveis rurais. 2018. Disponível em:

<http://www.incra.gov.br/tamanho-propriedades-rurais>. Acesso em: 20 dez. 2018.

INTERNATIONAL EGGS COMMISSION - IEC. Annual review 2015. London, UK, 2015. Disponível em: <http://www.internationalegg.com/wpcontent/uploads/2015/08/Annual Review_2015.pdf>. Acesso em: 10 dez. 2018.

JEPPSON, N. H.; RUDDY, J. A.; SALERNO, D. F. The statement of cash flows and the direct method of presentation. Management Accounting Quarterly, Montvale, v. 3, n. 1, p. 1-9, 2016. Disponível em: <https://www.imanet.org/insights-andtrends/management-accounting-quarterly/maq-index/2016/spring-2016?ssopc=1 >. Acesso em: 08 out. 2018. 
KAKIMOTO, S. K. Fatores críticos da competitividade da cadeia produtiva do ovo no estado de São Paulo. 2011. 156 f. Dissertação (Mestrado em Engenharia de Produção) - Universidade Federal de São Carlos, São Carlos, 2011.

KASSAI, S. As empresas de pequeno porte e a contabilidade. Caderno de Estudos, São Paulo, n. 15, p. 01-23, 1997.

KEMMIS, S.; MCTAGGART, R. The action research planner. 3rd ed. Geelong: Deakin University Press, 1988.

KEYNES, J. M. A teoria geral do emprego, do juro e da moeda. São Paulo: Atlas, 1982.

KNIGHT, F. H. Risk, uncertainty and profit. New York: Sentry Press, 1964. Disponível em:

$<$ https://mises.org/sites/default/files/Risk,\%20Uncertainty,\%20and\%20 Profit_4.pdf>. Acesso em: 24 out. 2018.

KRISHNAN, G. V.; LARGAY III, J. A. The predictive ability of direct method cash flow information. Journal of Business Finance \& Accounting, Oxford, v. 27, n. 1-2, p. 215-245, 2000.

LAGATTA, L. Impacto socioeconômico das políticas sanitárias sobre os estabelecimentos avícolas comerciais de postura da regional agropecuária de Limeira, Estado de São Paulo. 2014. 99 f. Dissertação (Mestrado em Ciências) Faculdade de Medicina Veterinária e Zootecnia, Universidade de São Paulo, Pirassununga, 2014.

LEONE, N. M. C. P. G. A dimensão física das pequenas e médias empresas: a procura de um critério homogeneizador. Revista de Administração de Empresas (RAE/FGV), São Paulo, v. 31, n. 2, p. 53-59, 1991.

As especificidades das pequenas e médias empresas. Revista de Administração da USP (RAUSP), São Paulo, v. 34, n. 2, p.91-94, 1999.

MAINGOT, M.; ZEGHAL, D. Financial reporting of small business entities in Canada. Journal of Small Business Management, Morgantown, v. 44, n. 4, p. 513-530, 2006.

MARION, J. C.; SEGATTI, S. Gerenciando custos agropecuários. Custos e Agronegócio (online), Recife, v. 1, n. 1, jan./jun. 2005. Disponível em: <http://www.custoseagronegocioonline.com.br/numero1v1/Gerenciando_custos.pdf>. Acesso em: 17 dez. 2018.

MIZUMOTO, F. M. Estratégias nos canais de distribuição de ovos: análise dos arranjos institucionais simultâneos. 2004. 95 f. Dissertação (Mestrado em Administração) - Faculdade de Economia, Administração e Contabilidade, Universidade de São Paulo, São Paulo, 2004. 
MIZUMOTO, F. M; ZYLBERSZTAJN, D. Relações contratuais no sistema agroindustrial de ovos. São Paulo: FEA/USP, 2008. (Série Working Paper 03/23).

MOSS, Q. Z.; ALHO, J.; ALEXANDER, K. Performance measurement action research. Journal of Facilities Management, Bingley, v. 5, n. 4, p.290-300, 2007.

MOZZATO, A. R.; GRZYBOVSKI, D. Análise de conteúdo como técnica de análise de dados qualitativos no campo da administração: potencial e desafios. Revista de Administração Contemporânea (RAC), Rio de Janeiro, v. 15, n. 4, p. 731-747, 2011.

NANTES, J. F. D. Gerenciamento da empresa rural. In: BATALHA, M. O. (Coord.). Gestão agro-industrial. São Paulo: Atlas, 1997, v. 1. p. 489-514.

OPLER, T. et al. The determinants and implications of corporate cash holdings. Journal of Financial Economics, Amsterdam, v. 52, n. 1, p. 3-46, 1999.

PAIS, M. A.; GAMA, P. M. Working capital management and SMEs profitability: Portuguese evidence. International Journal of Managerial Finance, Bingley, v. 11, n. 3, p. 341-358, 2015.

PARISI, C.; CORNACHIONE JUNIOR, E. B.; VASCONCELLOS, M. T. C. Modelo de identificação e acumulação de resultado sob a ótica do Gecon. Caderno de Estudos, São Paulo, n. 15, p. 01-16, 1997.

PEREZ, M. M. Uma contribuição ao estudo do processo de recuperação de empresas em dificuldades financeiras no Brasil. 2007. $222 \mathrm{f}$. Tese (Doutorado em Administração) - Faculdade de Economia, Administração e Contabilidade, Universidade de São Paulo, São Paulo, 2007.

PROCÓPIO, A. M. A utilização de modelos decisórios contábeis pelo pequeno e médio produtor rural - um estudo na região de Ribeirão Preto. 1997. 155 f.

Dissertação (Mestrado em Contabilidade e Controladoria) - Faculdade de Economia e Administração, Universidade de São Paulo, Ribeirão Preto, 1997.

RIBEIRO, L. G. T.; OLIVO, R. Ovo - ingerir ou não ingerir? Brazilian Journal of Surgery and Clinical Research, Maringá, v. 17, n. 1, p. 07-13, dez. 2016/fev. 2017. Disponível em: <https://www.lairribeiro.com.br/wp-content/uploads/2018/09/07-13OK-ori-template-BJSCR-17-1-Lair.pdf>. Acesso em: 20 dez. 2018.

ROSS, S. A.; WESTERFIELD, R. W.; JAFFE, J. F. Administração financeira. 2. ed. São Paulo: Atlas, 2002.

ROSS, S. A.; WESTERFIELD, R. W.; JORDAN, B. D. Princípios de administração financeira. São Paulo: Atlas, 1998.

SÁNCHEZ-RODRÍGUEZ, C.; SPRAAKMAN, G. ERP systems and management accounting: a multiple case study. Qualitative Research in Accounting \& Management, Bingley, v. 9, n. 4, p. 398-414, 2012. 
SCHWARTZ, F. F.; GAMEIRO, A. H. Análise de custo-benefício de sistemas de produção de ovos em gaiolas (em bateria) e sem gaiolas (caipira) nos Estados de São Paulo e Paraná. Empreendedorismo, Gestão e Negócios, Pirassununga, v. 6, n. 6, p. 132-147, 2017.

SCOTT, M.; BRUCE, R. Five stages of growth in small business. Long Range Planning, London, v. 20, n. 3, p. 45-52, 1987.

SERVIÇO BRASILEIRO DE APOIO ÀS PEQUENAS E MÉDIAS EMPRESAS SEBRAE. Perfil do produtor rural. Brasília: Sebrae, 2012. Disponível em: <http://www.sebrae.com.br/Sebrae/Portal\%20Sebrae/Anexos/perfil_do_produtor_rur al_-2012_.pdf>. Acesso em: 13 set. 2018.

Anuário do trabalho na micro e pequena empresa: 2013. Brasília: DIEESE, 2013. Disponível em: <http://www.sebrae.com.br/Sebrae/Portal\%20Sebrae/Anexos/Anuario $\% 20$ do\%20Trabalho\%20Na\%20Micro\%20e\%20Pequena\%20Empresa_2013.pdf>. Acesso em: 20 nov. 2018.

Sobrevivência das empresas no Brasil. Brasília: Sebrae, 2016a.

Disponível em: <http://www.sebrae.com.br/ Sebrae/

Portal\%20Sebrae/Anexos/sobrevivencia-das-empresas-no-brasil-102016.pdf>. Acesso em: 13 set. 2018.

Sobrevivência das empresas no Brasil: pesquisa quantitativa. Brasília: Sebrae, 2016b. Disponível em: <http://datasebrae.com.br/documentos/>. Acesso em: 13 set. 2018.

Fluxo de caixa (E-book). Brasília: Sebrae, 2016c. Disponível em: $<$ https://eadlms.sebrae.com.br/courses/novo-sebrae/FC1410/Linear/004_prod_fluxo caixa_m1/assets/sebrae/img/004.16.E.4.PDF_fechado.pdf>. Acesso em: 20 ago. 2018.

Perfil das microempresas e empresas de pequeno porte. Brasília:

Sebrae, 2018a. Disponível em:

<http://www.sebrae.com.br/sites/PortalSebrae/ufs/ro/artigos/perfildasmicroempresaseempresasdepequenoporte2018,a2fb479851b33610VgnVCM1000004c00210aRCR D>. Acesso em: 20 dez. 2018.

Quem somos. 2018b. Disponível em:

<http://www.sebrae.com.br/sites/Portal Sebrae/canais_adicionais/conheca_quem somos>. Acesso em: 20 nov. 2018.

Perfil do produtor rural (Data Sebrae). 2018c. Disponível em <https://datasebrae.com.br/ perfil-do-produtor-rural/\#quantos>. Acesso em: 10 jan. 2018.

Ferramentas - diário de caixa e controle de fluxo de caixa. 2018d. Disponível em: <http://www.sebrae.com.br/sites/PortalSebrae/ufs/sp/programas/ 
ferramentas-diario-de-caixa-e-controle-do-fluxo-de-caixa,e06ec49ae4af3610 VgnVCM1000004c00210aRCRD>. Acesso em: 11 jan. 2018.

SILVA, C. A. T; SANTOS, J. O.; OGAWA, J. S. Fluxo de caixa e DOAR. Caderno de Estudos (FIPECAFI), São Paulo, n. 9, p. 1-26, 1993.

SILVA, S. A. D. A importância da gestão nas pequenas propriedades rurais. Revista Acadêmica Conecta FASF, Luz, v. 2, n. 1, p. 272-285, 2017.

SOBRINHO, J. K.; FONSECA, R. A. Análise econômica da produção de ovos de galinhas poedeiras no munícipio de Toledo-PR. Revista Eletrônica Lato Sensu, Guarapuava, v. 2, n.1, 2007. Disponível em:

$<$ https://pt.scribd.com/doc/139497806/Analise-economica-da-producao-de-ovos-degalinhas-poedeiras-pdf>. Acesso em: 20 dez. 2018.

TAURINGANA, V.; AFRIFA, G. A. The relative importance of working capital management and its components to SMEs' profitability. Journal of Small Business and Enterprise Development, Bingley, v. 20, n. 3, p. 453-469, 2013.

UNIÃO BRASILEIRA DE AVICULTURA - UBABEF. The saga of the Brazilian poultry industry: how Brazil has become the world's largest exporter of chicken meat. São Paulo: UBABEF, 2011. Disponível em: <http://abpabr.com.br/files/publicacoes/fcc1856de5f036bb47a8a246a0781e26.pdf>. Acesso em: 02 dez. 2018.

WEIHRICH, $\mathrm{H}$. The TOWS matrix - a tool for situational analysis. Long Range Planning, London, v. 15, n. 2, p. 54-66, 1982.

WELSH, J. A.; WHITE, J. F. A small business is not a little big business. Harvard Business Review, Boston, July 1981. Disponível em: <https://hbr.org/1981/07/asmall-business-is-not-a-little-big-business>. Acesso em: 17 dez. 2018.

YAHYA, F.; ALI, S. A.; GHAZALI, Z. The relevance of agency conflicts in small and medium enterprises. International Journal of Advanced and Applied Sciences, Taipei, v. 3, n. 7, p. 41-45, 2016.

ZEN, S. et al. Evolução da avicultura no Brasil. Informativo CEPEA, Piracicaba, ano 1, n. 1, 2014. Disponível em: <https://www.cepea.esalq.usp.br/upload/ revista/pdf/0969140001468869743.pdf>. Acesso em: 02 dez. 2018. 


\section{APÊNDICE}

\section{TERMO DE CONSENTIMENTO LIVRE E ESCLARECIDO}

Projeto de pesquisa: $O$ fluxo de caixa como direcionador do processo de reestruturação de uma empresa avícola de postura comercial

Pesquisador principal/orientador: Prof. Dr. Augusto Hauber Gameiro

Pesquisador assistente: Rubens Corrêa Junior

Instituição: Universidade de São Paulo - Faculdade de Zootecnia e Engenharia de Alimentos

Laboratório: Laboratório de Análises Socioeconômicas e Ciência Animal

Endereço: Av. Duque de Caxias Norte, 225 - Campus USP, CEP 13.635-900, Pirassununga - São Paulo; www.usp.br/lae

Convidamos você a participar, como voluntário, do projeto de pesquisa intitulado: "O FLUXO DE CAIXA COMO DIRECIONADOR DO PROCESSO DE REESTRUTURAÇÃO DE UMA EMPRESA AVÍCOLA DE POSTURA COMERCIAL".

Esta pesquisa constitui o tema de dissertação de mestrado do aluno Rubens Corrêa Junior, no Programa de Pós-Graduação em Gestão e Inovação na Indústria Animal da Faculdade de Zootecnia e Engenharia de Alimentos da Universidade de São Paulo, tendo como orientador, o Prof. Dr. Augusto Hauber Gameiro.

O objetivo deste estudo é desenvolver um modelo simples, prático, mas suficientemente completo de gestão financeira por meio do instrumento de fluxo de caixa para tomada de decisão por pequenos e médios produtores agrícolas da avicultura de postura.

A pesquisa tem a finalidade implantar a ferramenta de fluxo de caixa, seu monitoramento e validação. A execução da pesquisa permitirá aos produtores gerirem seus negócios com mais organização e domínio dos resultados.

Sua participação nesta pesquisa consistirá em responder o roteiro de entrevista e participar de reuniões sobre assuntos relacionados a gestão da empresa como finanças, recursos humanos, comercial e produção. Entrevista e reuniões serão realizadas com os diretores e/ou colaboradores da empresa. $O$ tempo necessário para a entrevista ou reunião é de 30 a 90 minutos.

$\mathrm{O}$ risco e desconforto relacionados à sua participação dizem respeito à necessidade de tempo gasto para a entrevista ou reunião, e o constrangimento em relação a alguns assuntos, o que poderá levá-lo a desistir de participar da pesquisa, se assim desejar.

Os benefícios: não há benefícios diretos, mas sim benefícios indiretos. Os resultados contribuirão para o aumento da eficiência e da performance da empresa de avicultura de postura.

As informações obtidas por meio desta pesquisa serão para fins acadêmicos e científicos. Os dados serão publicados de forma a manter o anonimato e sigilo dos participantes. Você não terá nenhuma despesa e também não será pago por participar. 
Uma cópia deste Termo de Consentimento Livre e Esclarecido ficará com você, podendo tirar suas dúvidas sobre o projeto e sua participação. A qualquer momento você pode desistir de participar e retirar seu consentimento, sem precisar justificar e sem sofrer qualquer prejuízo.

Este projeto de pesquisa foi aprovado pelo CEPH-FZEA em (data de aprovação) sob número de parecer

Caso tenha dúvida ou sugestões relacionadas a esta pesquisa, você poderá entrar em contato com Prof. Dr. Augusto Hauber Gameiro, pesquisador responsável, telefone: (19) 3565-4224, e-mail: gameiro@usp.br, com o pesquisador assistente Rubens Corrêa Junior, pelo telefone: (19) 99182-0086, e-mail: correarubens_6@hotmail.com.

Comitê de Ética em Pesquisa com Seres Humanos da Faculdade de Zootecnia e Engenharia de Alimentos da USP, localizado na Av. Duque de Caxias Norte, 225, Campus Fernando Costa - USP, CEP 13635-900, Pirassununga/SP, telefone: (19) 3565-6759, e-mail: cepfzea@usp.br.

$\mathrm{Eu}$ (nome do participante) declaro que entendi os objetivos, os riscos e os benefícios de minha participação na pesquisa e concordo em participar.

de de 20

Assinatura do participante

Augusto Hauber Gameiro

Pesquisador principal/orientador

Rubens Corrêa Junior

Pesquisador assistente 